\title{
Quality of the Ground Water in Basalt of the Columbia River Group, Washington, Oregon, and Idaho
}

GEOLOGICAL SURVEY WATER-SUPPIY PAPER 1999-N

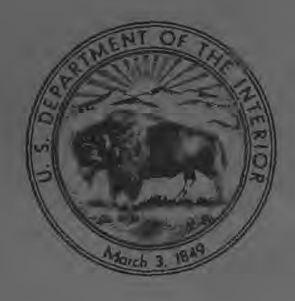




\section{Quality of the Ground Water in Basalt of the Columbia River Group, Washington, Oregon, and Idaho}

By R. C. NEWCOMB

CONTRIBUTIONS TO THE HYDROLOGY OF THE UNITED STATES

GEOLOGICAL SURVEY WATER-SUPPLY PAPER 1999-N

An analysis of constituents

and physical characteristics of

the ground water, including the

effect of time on its quality

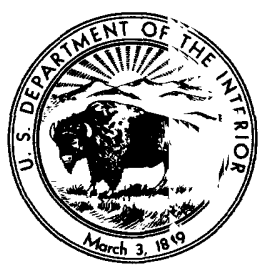




\section{UNITED STATES DEPARTMENT OF THE INTERIOR \\ ROGERS G. B. MORTON, Secretary}

GEOLOGICAL SURVEY

V. E. McKelvey, Director

Library of Congress catalog-card No. 72-600171 


\section{CONTENTS}

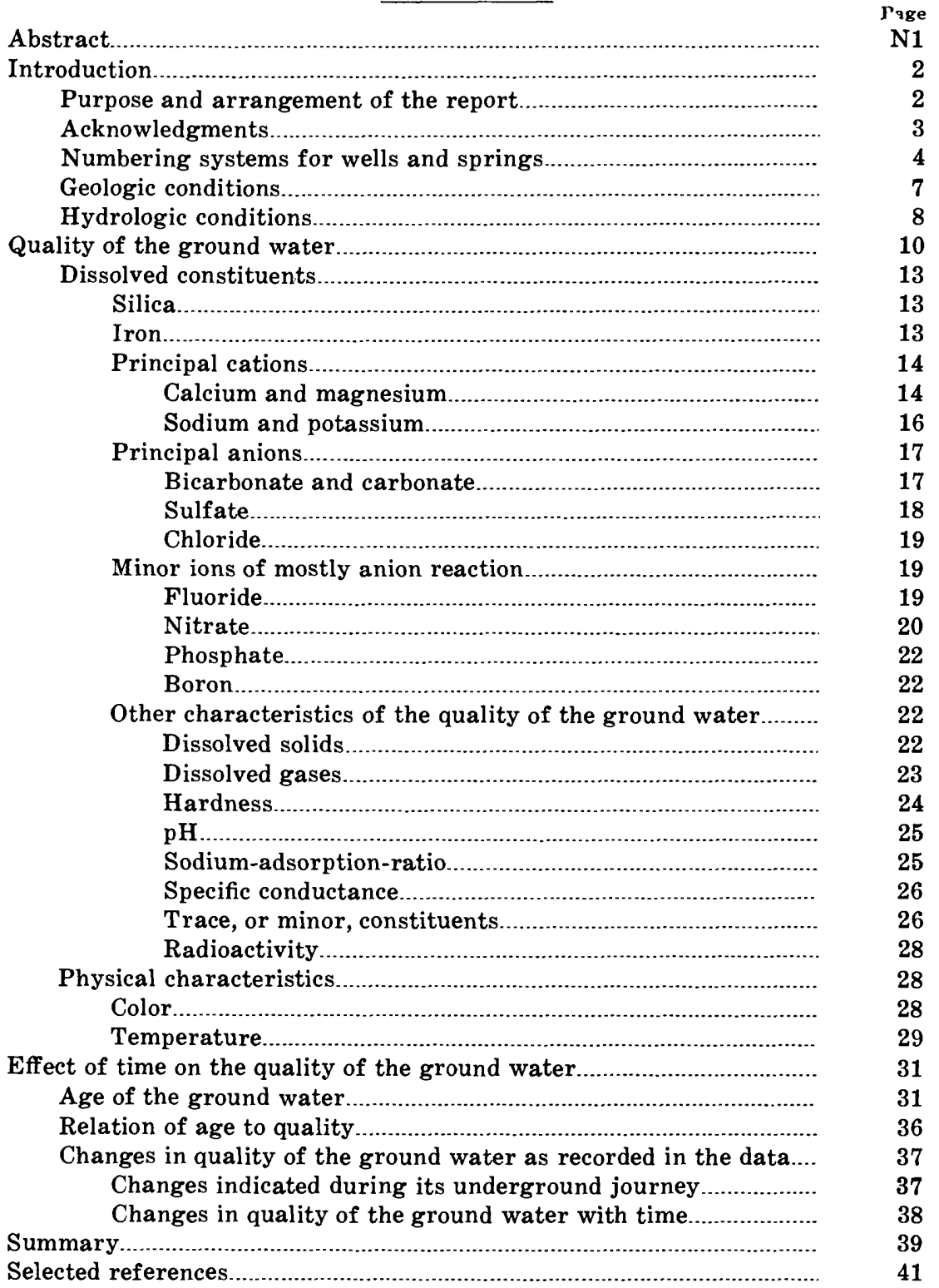




\section{ILLUSTRATIONS}

Plate 1. Map showing location of ground-water sampling sites in the basalt of the Columbia River Group, Washington, Oregon, and Idaho

In pocket

Figure 1. Map showing extent of the basalt of the Columbia River Group.

2. Bar graphs showing selected analyses of the prevalent and special types of ground water

3. Diagram showing chemical character of the prevalent and special types of ground water

4. Graph showing relation of depth of the water-yielding zone to the amount of nitrate

5. Graph showing general predominance of calcium over sodium in the ground water having $10 \mathrm{mg} / 1$ or more of nitrate.

6. Plot of SAR and specific conductance for 18 representative analyses of the generally prevalent ground water and six analyses of special types of ground water.

7. Geologic section showing wells in north-central Oregon for which carbon-14 ages have been obtained for water samples.

8. Diagram showing relation of altitude of the aquifer to the age of the ground water sampled from the basalt in the Pullman area, Washington.

9. Diagram showing relation of altitude of the aquifer to the age of the ground water sampled from the basalt in the Moscow area, Idaho

\section{TABLES}

TABLE 1. Chemical analyses of ground water in the basalt

2. Minor elements in the chemical analyses of ground water in the basalt

3. Radioactivity and radioactive chemical analyses of ground water in the basalt 


\title{
CONTRIBUTIONS TO THE HYDROLOGY OF THE UNITED STATES
}

\section{QUALITY OF THE GROUND WATER IN BASALT OF THE. COLUMBIA RIVER GROUP, WASHINGTON, OREGON, AND IDAHO}

\author{
By R. C. NewComb
}

\begin{abstract}
The ground water within the 50,000-square-mile area of the layered bas alt of the Columbia River Group is a generally uniform bicarbonate water having calcium and sodium in nearly equal amounts as the principal cations. The water contains a relatively large amount of silica.

The 525 chemical analyses indicate that the prevalent ground water is of two related kinds - a calcium and a sodium water. The sodium water is more common beneath the floors of the main synclinal valleys; the calcium water, elsewhere.

In addition to the prevalent type, five special types form a small part of the ground water; four of these are natural and one is artificial. The fcur natural special types are: (1) calcium sodium chloride waters that rise from underlying sedimentary rocks west of the Cascade Range, (2) mineralized water at or near warm or hot springs, (3) water having unusual ion concentrations, especially of chloride, near sedimentary rocks intercalated at the edges of the basalt, and (4) more mineralized water near one locality of excess carbon dioxide. The one artificial kind of special ground water $r$ as resulted from unintentional artificial recharge incidental to irrigation in parts of central Washington.

The solids dissolved in the ground water have been picked up on the surface, within the overburden, and from minerals and glasses within the basalt. Evidence for the removal of ions from solution is confined to calcium and magnesium, only small amounts of which are present in some of the sodiumrich water.

Minor constituents, such as the heavy metals, alkali metals, and alkali earths, occur in the ground water in trace, or small, amounts. The natural radioactivity of the ground waters is very low. Except for a few of the saline calcium sodium chloride waters and a few occurrences of excessive nitrate, the ground water generally meets the common standards of water good for most ordinary uses, but some of it can be improved by treatment. The water
\end{abstract}


is clear and colorless and has a temperature slightly higher than would be indicated by the accepted "normal" earth gradient. A small amount of iron is present in some of the water and a slight amount of hydrogen sulfide gas is present in water from most wells.

Carbon-14 determinations indicate that the water has been underground for periods ranging from modern times to several tens of thousands of years. Generally, an increase in the age of the water corresponds to depth and with location in the central parts of the main structural basins. The evidence of correlations between chemical characteristics and the age of the water is limited to the excessive nitrate which occurs in young, shallow ground water and to the apparent base-exchange removal of calcium and magnesium that has occurred where the ground water is old.

\section{INTRODUCTION}

\section{PURPOSE AND ARRANGEMENT OF THE REPO'T}

This report is prepared to compile the data on the quality of water in the Columbia River Group of basaltic rocks which underlie more than 50,000 square miles in the States of V'ashington, Oregon, and Idaho (fig. 1). The compilation, showing the types of water that occur in different parts of the basalt region, supplies data on the chemical conditions of the water in its natural state and gives information on some unnatural alterations of quality.

The report includes (1) data consisting of three tablos of analyses of ground-water samples and a map of the basalt region in which the sampling sites are located (pl. 1) and (2) text describing the chemical characteristics of both the prevalent and special types of ground water shown by the data. The data include 525 standard chemical analyses of water samples (table 1), 100 partial analyses of minor elements (table 2), and 27 analyses of groundwater radioactivity (table 3 ). The data in the tables are arranged by State, so the State having the most information and the greatest area of basalt (Washington) is listed first and the State having the least (Idaho) is listed last. Fill-in analyses were made during this research project to supplement the main body of data which was contributed by many investigators. In substance, the data include all the analytical information on the ground water in the basalt.

The analyses of the ground water were made on samples which were not uniformly distributed throughout the region. A disproportionate number of the samples has come from valleys because more wells are located there (pl. 1). Consequently, a disproportionate number of analyses shows the sodium-rich ground water that occurs in the synclinal areas as described later ir the report.

While most of the analyses in the tables are on remresentative samples of the ground water in the reported water-bearing zones, 
questions may be raised about the precise source of some of the samples analyzed. Owing to the stratigraphic arrangement of the individual aquifers in the basalt, some deep wells tap two or three water-bearing zones, one of which commonly yields more water than the others. In other wells (commonly unlined in most of their rock parts), different pressure heads occur in the separste aquifers, and circulation between aquifers takes place within the wells, especially when they are not being pumped. Also, in some valley areas where permeable sedimentary deposits overlie the basalt, well casings that don't have adequate sealing have be? set to the top of the basalt; consequently, water from the overlying materials descends into the wells. Samples that are questicnable with regard to their precise source, insofar as they could be identified by lack of uniformity in multiple samples and by other criteria, were omitted; however, several tens of analyses in talle 1 may be questionable as to the accuracy with which they represent the ground water in the basalt or as to the particular zone shown to be producing the water. Nevertheless, the geologic and hydrologic requirements, met both by samples and analyses for inclusion in this report, make the data generally valid. An awar:ness of the sampling hazards, not to mention the higher grade of present-day well construction and completion, should make groundwater sampling more representative in the future.

\section{ACKNOWLEDGMENTS}

Many analyses have been taken from sources listed in the references. Other analyses, taken from the files of the Geological Survey in Washington, Oregon, and Idaho, were originally made through the Federal and cooperative programs between the Survey and State and local governmental agencies. Numerous analyses were contributed by the Oregon State Board of Health, the U.S. Army Corps of Engineers, the U.S. Bureau of Sport Fisheries and Wildlife, the U.S. Bureau of Reclamation, and the Idalo Board of Health. The source of each analysis is shown in tle tables.

\section{NUMBERING SYSTEMS FOR WELLS AND SPRINGS}

Wells and springs from which water samples were taken for the analytical data discussed in this report are numbered in accordance with the rectangular system of land subdivision. In Washington and Oregon the township and range numbers are laid out from the Willamette base line and meridian; in Idah?, from the Boise base line and meridian. The custom of numberirg wells using township and range designations, followed for many 
EXPLANATION

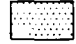

Volcanic rocks younger than the basalt

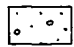

Sedimentary rocks over basalt and older rocks in the Portland and Salem areas

Basalt of the Columbia River Group. Areas in which basalt is overlain by younger sedimentary deposits are included except near Salem and Portland

$124^{\circ}$

3
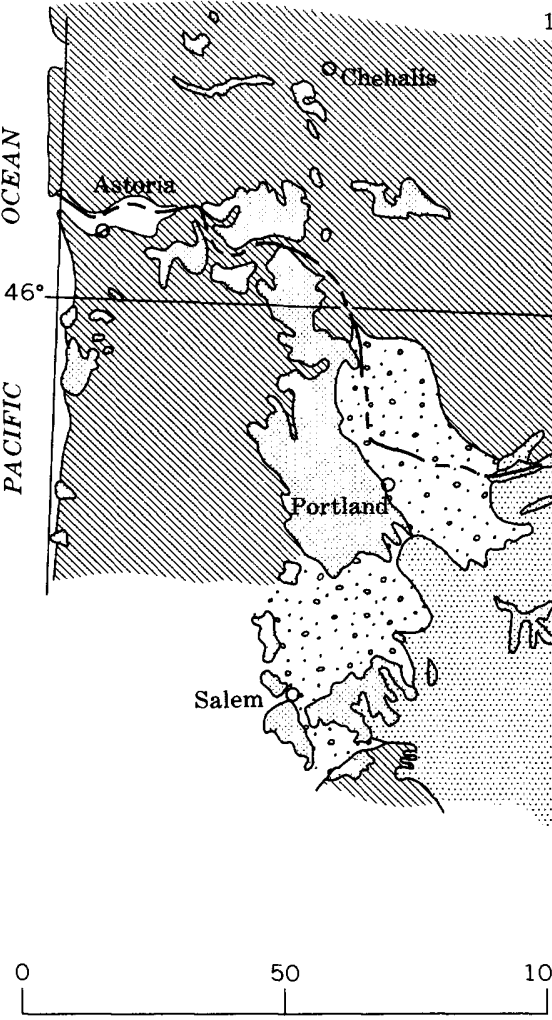

Areas where bedrocks are older than the basalt. Not shown are inliers within the basalt area, mostly near the eastern and southern edges

\section{Contact}




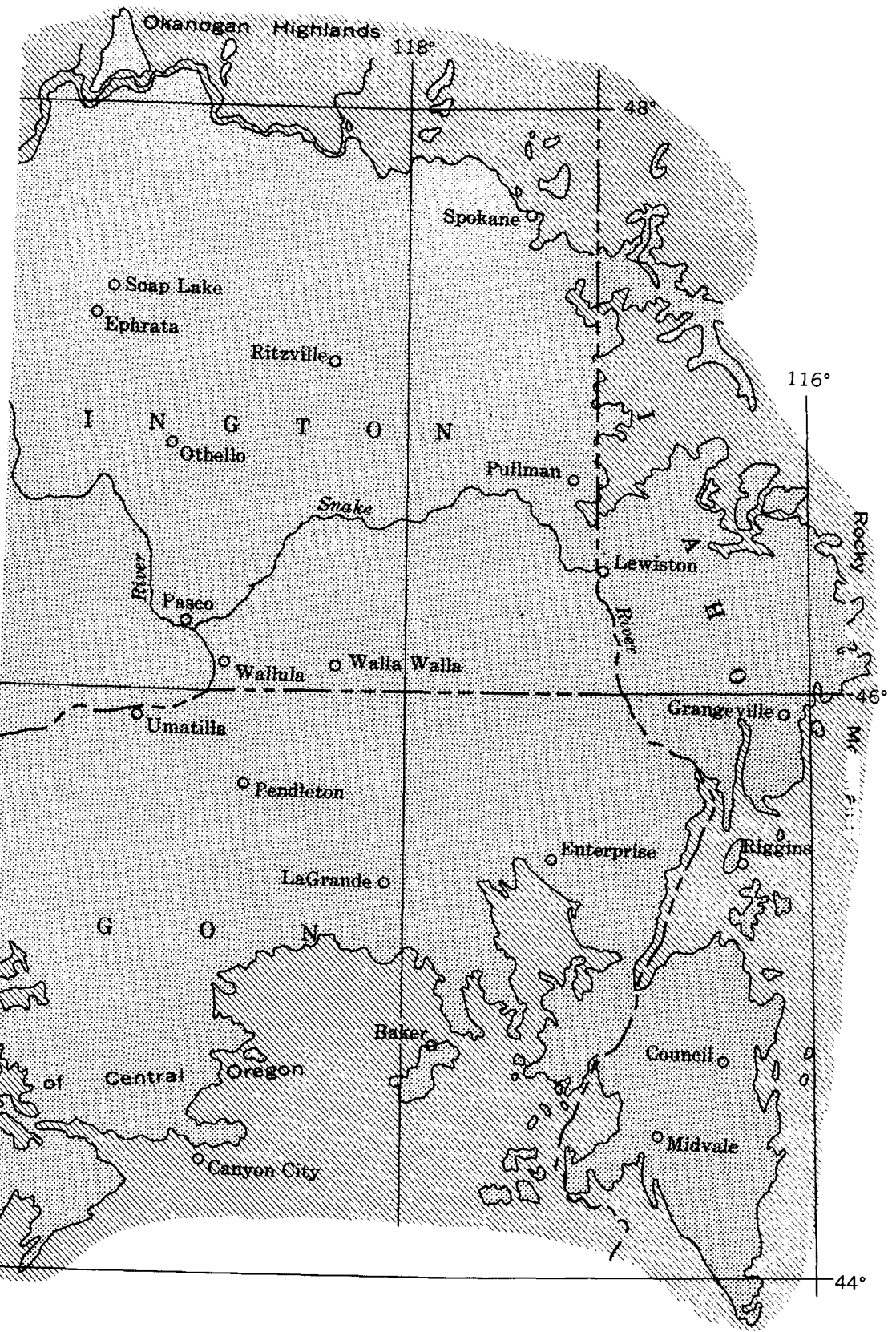

of the Columbia River Group.

wise, the letter " $\mathrm{S}$ " is dropped for townships south of the base line in Oregon, because most townships are south of the base line. In Idaho, all township and range designations retain their directional 
letters. This report contains no records of wells in Washington west of the Willamette meridian. Where dropping the directional letters for township and range identification of well and spring numbers in Oregon or Washington might cause confusion, the State name has been given.

The numbers preceding the dash indicate the township and range; the section number and 40-acre-tract subdivision, in that order, follow the dash. In Oregon and Washington, one letter indicates the 40-acre subdivision of the section, as shcwn in the diagram. In Idaho, two letters are used to designate a 40-acre tract.

\begin{tabular}{|c|c|c|c|}
\hline$D$ & $C$ & $B$ & $A$ \\
\hline $\mathrm{E}$ & $\mathrm{F}$ & $\mathrm{G}$ & $\mathrm{H}$ \\
\hline $\mathrm{M}$ & $\mathrm{L}$ & $\mathrm{K} \mathrm{K} 1$ & $\mathrm{~J}$ \\
\hline $\mathrm{N}$ & $\mathrm{P}$ & $\mathrm{Q}$ & $\mathrm{R}$ \\
\hline
\end{tabular}

Washington

and

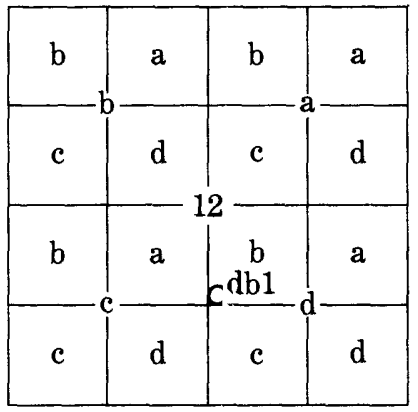

Idaho

Oregon

Thus, a well numbered $10 / 30-15 \mathrm{~K} 1$ in Washingtor is in the NW1/4,SE $1 / 4$ sec. $15, T .10$ N., R. 30 E.; the same number in Oregon is in the same section subdivision but in T. 10 S., R. 30 E. Both wells would be the first wells numbered in their 40-acre tracts. In Idaho, a well numbered $16 \mathrm{~N} / 1 \mathrm{~W}-12 \mathrm{db} 1$ would $\mathrm{b}$ ? the first one numbered in the NW1/4,SE1/4, sec. 12 , T. 16 N., R. 1 W., of the Boise base line and meridian, as shown in the diagram above.

The analyses in the tables are listed by township and range within each State. In Washington, listings are northward by township tiers within each of which the ranges follow successively eastward. In Oregon, each northward tier contains a.n eastward succession of ranges followed by a westward successic 7 from the meridian; the southward tiers of townships are arranged in the same manner as the northern tiers. In Idaho, the ranges follow successively within each township tier northward from the base line.

A serial number from 1 to 525 is assigned to t1 @ analyses arranged by State and well numbers in table 1. These serial numbers are used for reference throughout this report. 


\section{GEOLOGIC CONDITIONS}

The basalt of the Columbia River Group underlies a regior of about 50,000 square miles in Washington, Oregon, and Idaho (fig. 1). The main body of the rock unit lies between the Rocky Mountains on the east and the Cascade Range on the west. In and south of the Columbia Gorge, the basalt crosses the Casc $\times$ de Range and is interbedded with sedimentary and volcanic-sedimentary units north from the Salem, Oreg., area as far as the Chehalis River valley in Washington (pl. 1).

In the central part of the region, the basalt has a general thickness of 4,000-5,000 feet. It tapers out on the prebasalt surface at the edges, but the western and southern edges are complicated by the centrally located extension to the west and by the presence of other basaltic lavas of similar age to the south. In a few places west of the Cascade Range, the basalt reaches a thickness of 1,000 feet but is generally less than 500 feet thick.

The rock unit consists largely of accordantly layered basalt which accumulated as flow upon flow of highly fluid lava. The lava flows, which constitute the principal stratigraphic units, vary from 10 to 200 feet in thickness, averaging about 100 feet. The flows are made up of one or more arrivals of lava, called fow units; consequently, the stratigraphy of the layering varies considerably from place to place. Small amounts of interbedded sedimentary materials occur, especially in the top 1,000 feet in the west-central part of the basalt region and for the entire thickness at places around the edges of the basalt accumulation. For the most part, the interbedded materials are considered to be related to the Latah Formation at the northern edge, the Latah and Payette Formations at the eastern edge, the Mascall Formation at the southern edge, the Ellensburg Formation at the northwestern edge, and the Astoria Formation at the far western edge.

In certain vertical sections around the edges of the basalt, the interbedding of sedimentary layers is so great that the sedimentary materials predominate over basalt. Consequently, the quality of the ground water can differ from that sampled in other sections where the ground water has moved through exclusively basaltic materials.

The basalt is a largely uniform black or dark-gray rock. Soventy-five percent of the average basalt consists of crystals c.nd microcrystallites of labradorite, augite, and magnetite. The remaining 25 percent, occupied by intercrystalline area, is composed of a glassy groundmass containing microlite beginnings of still smaller crystals. Olivine forms 1-5 percent of some of the liva 
flows. Apatite and cristobalite have been identified as accessory minerals, but primary fluorite has not been reported. Some lava flows are porphyritic and have megascopic labradorite and pyroxene crystals arranged in a distinctive habit (Irwin, 1946; Jones, 1950 ; Mackin, 1961).

Rubbly lava-breccia is largely confined to the tops of some lava flows, to pillow-palagonite occurrences where the lave has been chilled by flowage over or into water, and to rare occurrences of autobreccia wherein the lava has broken itself by movement during solidification. Cooling-contraction joints divide the basalt into blocks ranging from 1 inch to 10 feet across; some form of vertical hexagonal columnar jointing is the most prevalent joint system. The cooling joints are open cracks near the surface but are tightly closed at depth within the thick flows.

Joint-block surfaces of some lava flows are coated with iron oxide, but the rock is not deeply oxidized except near the land surface in some places. The lack of alteration in deep openings, drill cuttings, and other penetrations indicates that oxidation had not extended greatly downward from the surface, as anything more than a thin coating, before each successive flow was covered. Fresh, untarnished crystals of iron pyrite, observed on the sides of openings in some water-bearing zones, attest to strong reducing conditions in aquifers several hundred feet below the top of the basalt.

The integrated porosity sufficient to transmit ground water in quantities that will afford large yields, $+1,000 \mathrm{gpm}$ (gallons per minute), to wells is limited largely to the fractured tons of some flows, and stratigraphic zones of rubbly basalt (Newcrmb, 1959, p. 4-6). These "adequately permeable" zones include only a small part of the basalt, probably comprising less than 6 percent of the top 1,500 feet of the basalt (Newcomb, 1969, p. 12).

The basalt was folded, warped, and faulted during the tectonic deformation of Pliocene and Quaternary time, the Cascadian orogeny (Newcomb, 1970). Tilting and fault displacement have exposed the permeable zones of anticlines and monoclines to recharge water from precipitation and streamflow; this recharge water migrates laterally to the downwarped parts of the basalt. Sharp folds and the crushed zones along faults generally constitute barriers to this lateral movement (Newcomb, 1961).

\section{HYDROLOGIC CONDITIONS}

The basalt underlies the land surface in areas that receive annual precipitation ranging from less than 10 inches to more than 100 inches. The average depths of water that passes through the 
soil and overburden and migrates downward to recharge the ground water in the basalt range from zero beneath some desert terrains to more than 1 foot in some river basins of the Elue Mountains (Newcomb, 1965, p. 18). The ease with which water at the surface may transfer downward in the basalt depends largely on the position in which the layers of basalt lie: if they are horizontal, the downward passage may be largely denied; if they are tilted, and the ends of permeable zones are exposed, the downward passage may be easy. The records of water levels in wells indicate that the natural recharge to ground water in the basalt is greatest where inclined layers of basalt are truncated by the land surface on which streams flow or abundant precipitation falls (Newcomb, 1959, p. 7-8).

From the recharge area, the water follows the courses afforted by the permeable openings in the basalt, and moves toward its ultimate discharge in response to the drive of the pressure Eradient. Its life as ground water may be short or long depending on whether it entered a permeable unit beneath a mountain valley and was discharged a few months later from a hillside spring, or whether it drained deeply, to travel many thousands of years through the basalt beneath synclinal valleys. Its course may have been at shallow depths in cool rocks, or it may have penetrated the warmer parts of the basalt. The water may have circulated completely within a single stratigraphic zone, or it may have migrated from one aquifer to another by slow circuitous high pressure through stratigraphic overlaps, joints, or fault-shattered zones. It may have received an inflow of more concentrated solutions from greater depths, or it may have been diluted by less mineralized water. These and many other possible experiences in the subsurface passage of the water, both before and after it arrived in the basalt, can change the water's quality and af'ect the content of the dissolved materials carried by ground water.

The main natural mode of ground-water discharge from the basalt is through numerous springs, many of which inconspicuously feed streams. Single springs discharging more than 1,000 $\mathrm{gpm}$ are rare, though discharge from numerous small springs in an area of several tens of acres may add up to that quantity. Most springs discharge less than $10 \mathrm{gpm}$ at single orifices wrich may be arranged at intervals of a few hundred feet along the base of the outcropping aquifer.

Passage of the ground water into the oxidizing environment of the atmosphere causes the precipitation of iron oxide at some springs, but there is a general absence of precipitates or incrustations at most springs where water flows from the basalt. Like- 
wise, the formation of incrustations and coatings is lacking at all but a few wells. Two wells (analyses 330 and 331 cf table 1) at Mosier, 14 miles northwest of The Dalles, are the only ones known to the author that require periodic treatment to relieve yield-reducing incrustations.

\section{QUALITY OF THE GROUND WATER}

In general, the ground water of the basalt is satisfactory without treatment for most ordinary uses of water. Some of the water needs improvement for use in steam boilers, aeration to remove hydrogen sulfide gas, softening to lower soap consumption, or, in a few places, treatment to remove iron. From place to place, the dissolved solids in water from the basalt vary considerably; the common extremes range from less than $200 \mathrm{mg} / 1$ (milligrams per liter) to as much as $500 \mathrm{mg} / 1$. The most mineralized types of water have migrated into the basalt from other rocks and occur under specific sets of geologic conditions; these are described later in the report as some of the special types of ground water.

Most of the ground water discharged from springs ard sampled at wells comes from the youngest part of the basalt, the top 2,000 feet. The average ground water in this top 2,000 feet is moderately hard, nearly iron free, and clear. Silica, calcium, sodium, and bicarbonate are the principal dissolved solids. Much of the ground water has a slight hydrogen sulfide odor that is easily removed by aeration, and, otherwise, the water is of generally good physical and chemical quality.

A general illustration of the composition of the dissolved solids is shown by bar graphs in figure 2 and by the compositional diagram in figure 3 . Table 1 shows that a great majority of the analyses are on similar calcium sodium bicarbonate ${ }^{1}$ waters of rather uniform characteristics. The calcium sodium bicarbonate water and a similar water having a predominance of scdium over calcium are considered to be the prevalent ground water of the basalt. In some of the descriptions appearing later in the report, this water is referred to as "the prevalent ground water" or "the ground water of the basalt."

Ground waters having peculiar amounts of dissolved solids are termed "special" types of ground water in this report. The special ground waters include (1) calcium sodium chloride waters rising

\footnotetext{
${ }^{1}$ The principal ions are used as adjectives in forming a brief designation for cortain chemical characteristics of the ground waters. In these multi-word adjectives, the ion of greatest reacting concentration is listed first and progressively lesser ions follow, the anions l'ated after the cations.
} 


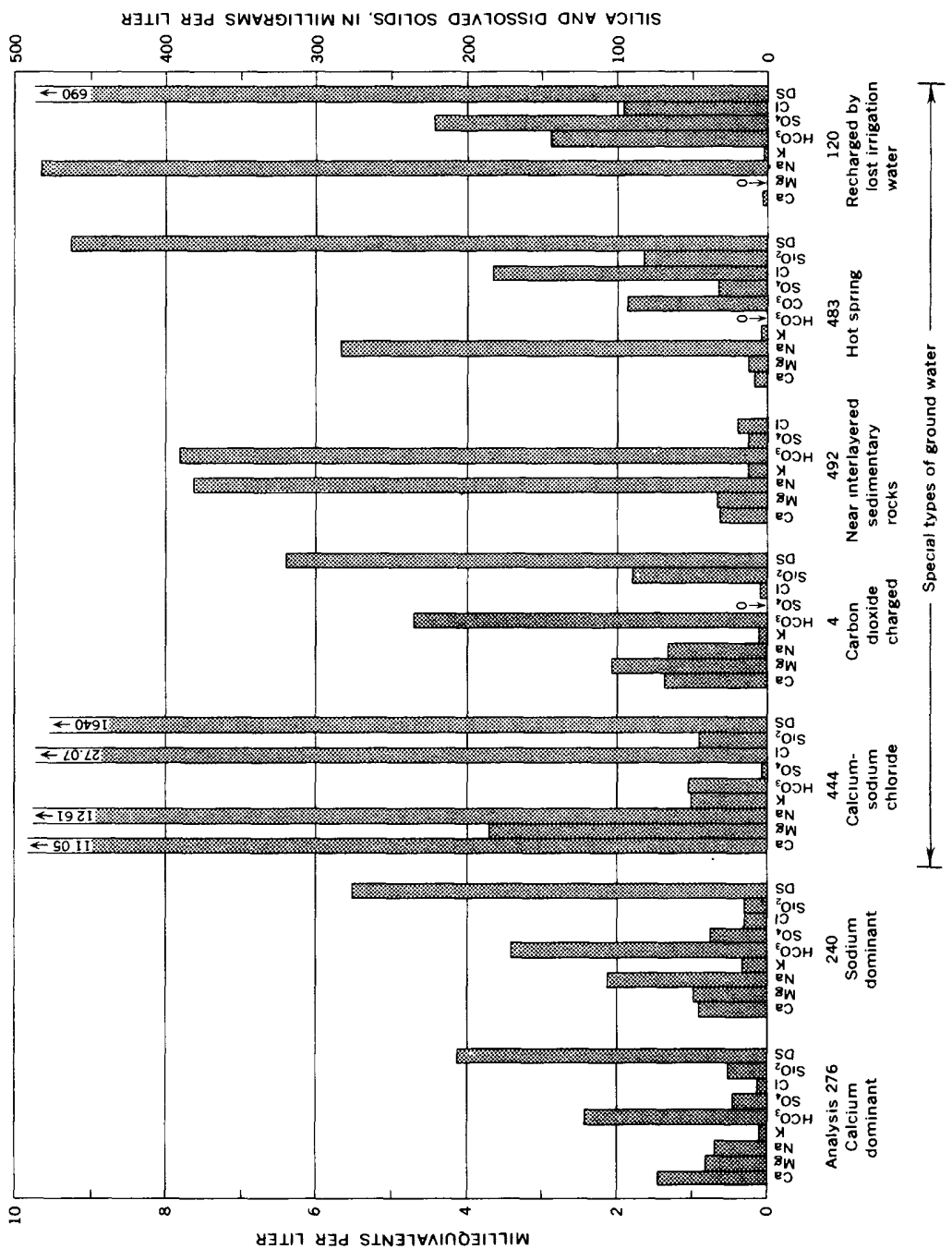

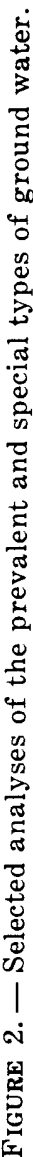


into the basalt from underlying sedimentary rocks west of the Cascade Range, (2) sodium- and calcium-rich sulfate clloride and

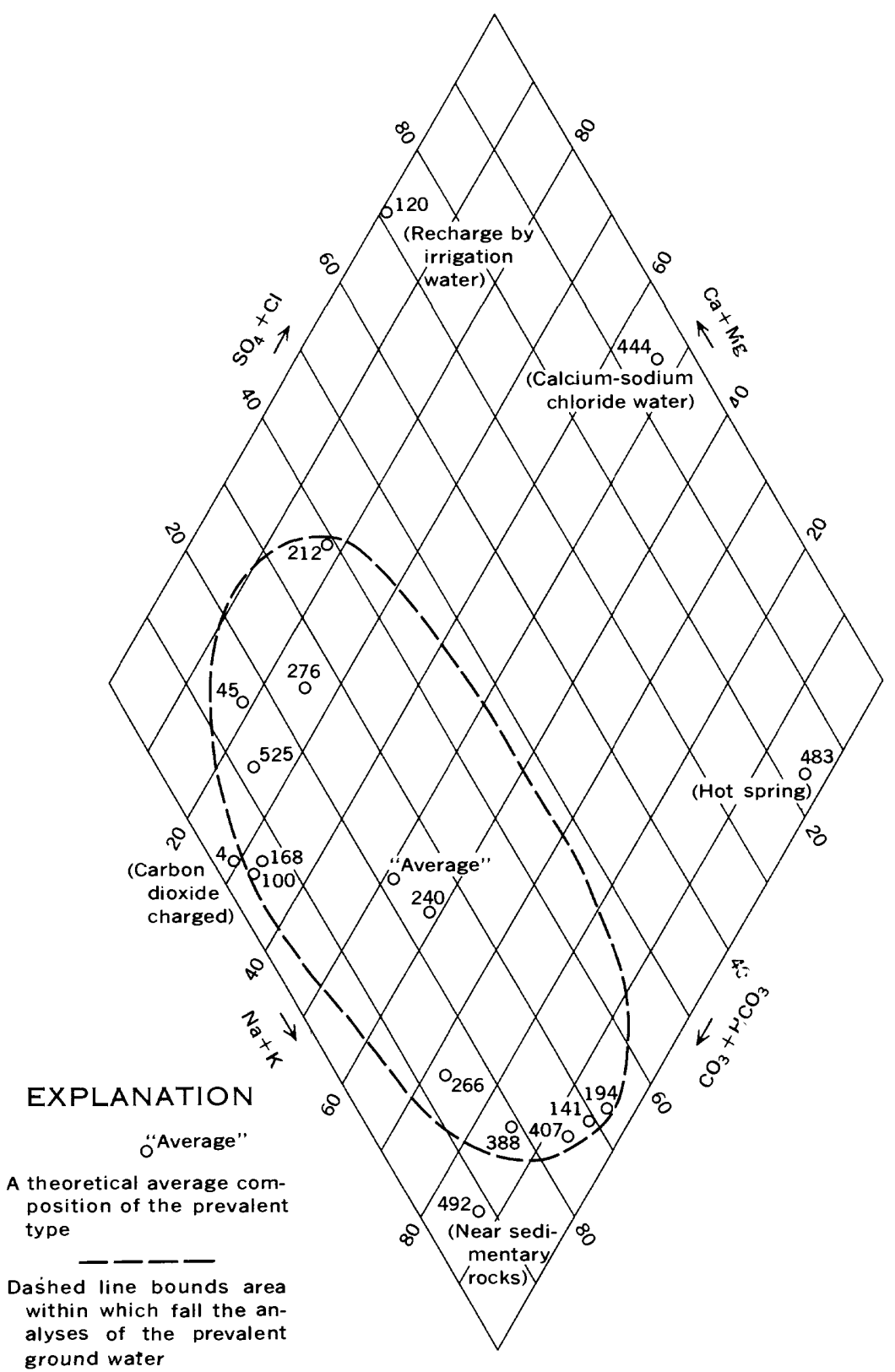

PERCENTAGE REACTING VALUES

Figure 3. - Chemical character of the prevalent and special types of ground water. 
bicarbonate waters recharged to dipping basalt layers by escaped irrigation water from the Columbia Basin Irrigation Project (between Pasco and Ephrata in central Washington), (3) mineralized water at or near warm or hot springs, (4) mineralized water at or near the carbon dioxide charged Klickitat Springs (in southern Washington, 16 miles north of The Dalles), and (5) water of various anomalous ion concentrations, especially chloride-rich waters, which occur within and near sedimentary rocks that are interlayered with the basalt around the edge of the basalt region.

The general composition of the ground water of the basalt is described further in the following section. The ranges and average concentrations of the principal ions of the dissolved solids, the distinctive features of their geologic occurrence in the ground water, and some of the effects of these ions on the uses of water are described to augment the data listed in the tables and shown in the illustrations.

\section{DISSOLVED CONSTITUENTS SILICA}

In 381 analyses of the prevalent ground water, silica ranges from 18 to $121 \mathrm{mg} / \mathrm{l}$ (table 1 ). In most of the analyses, silica ranges from 40 to $80 \mathrm{mg} / \mathrm{l}$ and a value of about $55 \mathrm{mg} / \mathrm{l}$ is average. There is a general relation between the highest silica values and the temperature of the water, the highest silica values (121 and $115 \mathrm{mg} / \mathrm{l}$ ) being from water of relatively high temperature $\left(27.2^{\circ} \mathrm{C}\right.$, or $\left.81.5^{\circ} \mathrm{F}\right)$. However, the comparative relation between temperature and silica content is not consistent; for example, the hottest water (analysis $483,79.5^{\circ} \mathrm{C}$, or $175^{\circ} \mathrm{F}$ ) has only $81 \mathrm{mg} / \mathrm{l}$ silica. There is a lack of consistent relation between the silica content and the calcium or sodium content or the value of other characteristics, such as $\mathrm{pH}$.

The general uniformity of the silica content in wells of all depths (ranging generally from 200 to 1,200 feet) indicates that the ground water reaches a silica equilibrium with the basalt fairly early in its underground history. Silica is of little sigrificance in the quality of water for most uses, except that its deposition in boilers and other hot-water containers can cause undesirable scale.

\section{IRON}

Many of the values for iron listed in table 1 are from records of analyses in which the type of iron determination, whether iron in solution at time of sampling or at time of analysis, could not be ascertained. Those for which a total iron at time of sampling was definitely indicated are so shown as total iron in table 1. 
Of the 444 iron determinations, 377 , or 85 percent, are less than $0.30 \mathrm{mg} / \mathrm{l}$ of iron, the content commonly taken as the point above which its presence in the water becomes detrimental for many water uses. Most of the 67 analyses in which iron equals or exceeds $0.30 \mathrm{mg} / \mathrm{l}$ range generally between that value and $2.4 \mathrm{mg} / \mathrm{l}$, but one water sample from a faulted area (analysis 470) has $16.5 \mathrm{mg} / \mathrm{l}$, and another from western Oreron (analysis 485$)$ has $9.7 \mathrm{mg} / \mathrm{l}$. One of the Gas-Ice Corp. wells $(4 / 13-$ $24 \mathrm{H} 4)$ at Klickitat Springs has $11.0 \mathrm{mg} / \mathrm{l}$, and one well $(39 \mathrm{~N} / 15 \mathrm{~W}-$ 8aa2) at Moscow, Idaho, has $6.5 \mathrm{mg} / \mathrm{l}$. Both of these latter waters are special types, respectively a carbon dioxide charget type and a water from basalt containing much interbedded sedimentary material.

The data indicate there is no correlation between the iron content and the depth of the aquifers, nor is there any geographical distribution of the iron content within the region, not even a consistent difference between the areas west and east of the Cascade Range. Differences in iron content have been noted between aquifers tapped during the drilling of a single well and between nearby wells drilled to the same aquifer. The 12 analyses (100111 of table 1) listed for seven wells in the same general aquifers at Pullman, Wash., show a range from 0.03 to $0.50 \mathrm{mg} / \mathrm{l}$. Some large concentrations of iron have been found to result from other influences-improperly sealed or rusted casing.

The average well water from the top 1,000 feet of the basalt, containing about $0.20 \mathrm{mg} / \mathrm{l}$ of iron, will lightly stain white cloth or porcelain plumbing fixtures but is generally satisfactory for other uses and does not ordinarily sustain heavy growths of iron bacteria in tanks and reservoirs. All observations known to the author indicate that the iron occurs in solution in the ferrous state in balance with bicarbonate anions; it is removable by aeration followed by filtration or by other common methods of iron removal.

\section{PRINCIPAL CATIONS \\ Calcium and Magnesium}

In the prevalent type of ground water, these major cations together usually range from 20 to about $100 \mathrm{mg} / \mathrm{l}$. Within that range magnesium varies considerably but occurs at about onefourth to one-half the milligrams-per-liter concentration of calcium, except in the waters in which sodium exceeds the calcium. In the sodium waters, the magnesium content may be only $1 / 10$ $1 / 4$ that of calcium. Together they form the bulk of tre elements 
that unite with soap to form the relatively insoluble compounds that are the principal effect of hard water.

Calcium ranges from 8 to $100 \mathrm{mg} / \mathrm{l}$ where it is the dominant cation in the prevalent ground water; it averages about $23 \mathrm{mg} / \mathrm{l}$. In the waters which contain more sodium than calcium or equal amounts of the two, the calcium content ranges generally between 5 and $30 \mathrm{mg} / \mathrm{l}$, averaging about $15 \mathrm{mg} / \mathrm{l}$. Within the calcium waters there is a general lack of a consistent increase in calcium as the aquifer depth or the apparent time the water has been underground increases, indicating that the calcium content is present soon after water infiltrates and moves down. This would indicate that most of the calcium is picked up in the soil zone and the surficial weathered zones of the basalt. This relation also may indicate that the calcium in solution is not augmented by large additions from the decomposition of basaltic glass, labradorite, and pyroxene deep within the basalt. In the sodium waters, found mainly in the synclinal basins, calcium occurs at its lowest concentrations ( 2 and $1.5 \mathrm{mg} / \mathrm{l}$ in analyses 420 and 421 at Umatilla), indicating that base exchange with sodium may remove calcium from the ground waters progressively as the content of sodium increases. The greatest concentrations of calcium (200-600 mg/l, analyses 444 and 446) occur in a special type of ground water-the calcium sodium chloride waters that rise up into the basalt from underlying sedimentary rocks in Washington and western Oregon.

The magnesium content ranges from 0 to $106 \mathrm{mg} / \mathrm{l}$ and, in $\mathrm{g}: \mathrm{n}-$ eral, follows the variations of calcium content, previously described. Magnesium is entirely lacking in two analyses (120 and 337 ) of sodium-rich water taken from wells $15 / 28-24 \mathrm{~L} 1$ in Washington and $2 \mathrm{~N} / 25-28 \mathrm{D} 1$ in Oregon. The sample from vell 15/28-24L1 was taken after artificial recharge incidental to irrigation had converted the water to a sodium sulfate solutionthe type of water in which the least amount of magnesium occurs. The two greatest concentrations of magnesium, both $106 \mathrm{mg} / \mathrm{l}$, also occur in special types of water-the carbon dioxide charged water near Klickitat Springs (analysis 3) and the calcium magnesium sodium sulfate bicarbonate chloride water (analysis 89) resulting from flushing of salts downward by irrigation water.

The $1: 3 / 8$ ratio of calcium to magnesium content indicated for the prevalent ground water from the basalt, when converted to equivalents per million, gives a chemical-reacting ratio of about $2: 1$. This ratio is in the range given by $\operatorname{Hem}(1959$, p. 82$)$ as indicative that the source of the magnesium in the water lies in the solution of magnesium silicate minerals. Such a source for 
the magnesium in the ground water of the basalt would fit with the readily available mineral sources: the basaltic glass. pyroxene, and (in some of the lava flows) olivine.

\section{Sodium and Potassium}

In the prevalent ground water, sodium ranges from 6.2 to 100 $\mathrm{mg} / \mathrm{l}$ and potassium from 0.4 to $26 \mathrm{mg} / 1$. The sodium content varies greatly between the sodium waters that predominate beneath the synclinal basins ${ }^{2}$ and the calcium-rich waters elsewhere. The ratio of sodium to potassium, in milligrams per liter, ranges from $15: 1$ to $3: 1$ and averages near $5: 1$. The average content of sodium in the calcium-rich waters is about $25 \mathrm{mg} / \mathrm{l}$ and within the sodium waters is about $50 \mathrm{mg} / 1$; its average is about 32 $\mathrm{mg} / \mathrm{l}$ in the prevalent ground water. Of 341 sources of the ground water (table 1) for which the analyses contain values for both calcium and sodium, 143 show a predominance of scdium over calcium by greater than $5 \mathrm{mg} / \mathrm{l}$, as compared with 122 that show a similar predominance of calcium over sodium. There are 76 sources in which neither predominated by $5 \mathrm{mg} / \mathrm{l}$. Overall, the analyses given in table 1 show sodium to be slightly predominant over calcium; but, because a disproportionately large percentage of these samples was taken in synclinal basins, where sodium is generally high, an evaluation of the regional conditions must allow for lack of full representation for the calcium-rich ground waters. In the sodium-rich ground waters of the synclinal areas of the basalt, concentrations of $50-110 \mathrm{mg} / \mathrm{l}$ of sodium are common (as in analyses 32-34, 140,141, 358-360, and 368-391), and in these waters the milligrams-per-liter ratio of sodium to potassium is commonly near $10: 1$.

The analyses show no consistent relation between the content of sodium or potassium and the depth at which ground water is taken from the basalt. Possibly some correlation would show, if the samples from deep wells were from strictly separate waterbearing zones. Where the main aquifers are believed known, the analyses of some of the ground water at shallower depth in the basinal areas have greater sodium and potassium content than the deeper ground water. This relation is shown by analyses such as 139 and 140, where the deeper water (analysis 139) from "below 700 feet" has calcium and magnesium comparable to the combined milligrams per liter of sodium and potassium. In the shallower zone sampled from a depth of 170-304 feet (analysis

'The principal tectonic structures of the basalt, including the synclinal areas that are the main localities of this sodium-rich water, are shown on Miscellaneous Geologic Investigations Map I-587 (Newcomb, 1970). 
140), the combined content of sodium ( 86 and $81 \mathrm{mg} / \mathrm{l}$ ) and of potassium ( 26 and $12 \mathrm{mg} / \mathrm{l}$ ) are nearly twice what they are in the deep zone (analysis 139); also, it is.more than 10 times the combined milligrams per liter of the calcium and magnesium in the shallow zone (analysis 140). However, an opposite condition, a greater sodium and potassium concentration with greater derth, is shown by analyses 371-400 for the wells at the Umatilla Ordnance Depot. Outside the desert basins, in places where one rell is believed to tap entirely deeper zones, analyses (such as 135 at Pullman) indicate that the sodium and potassium determinations of the deeper aquifers are nearly identical to those in the shallower zones (analyses 100 and 133).

Calcium sodium chloride water, a special type of ground water in the basalt at places in Washington and western Oregon, is the most common form of high-sodium water (analyses 326, 444, and 446). In the sodium-rich part of another special type of ground water, that newly recharged by irrigation water (analyses 120 and 261), the sodium is associated mostly with bicarbonate and sulfate and secondarily with chloride.

\section{PRINCIPAL ANIONS}

Bicarbonate and Carbonate

Bicarbonate is the principal anion of the prevalent ground water; it ranges from 50 to $300 \mathrm{mg} / 1$ in these waters, wher?as the other major anions, sulfate and chloride, commonly amount to less than $10 \mathrm{mg} / \mathrm{l}$. A value of $150 \mathrm{mg} / \mathrm{l}$, slightly below the median of the range, is about the average. The total content of bicarbonate varies generally with the amount of dissolved solids. There is no obvious relation between the bicarbonate content and the depth at which the ground water occurs within the basalt.

Of 356 analyses, only 69 show any carbonate ions present. Of these 69 analyses, all but a few are sodium-rich waters. Of the 18 analyses having more than $8 \mathrm{mg} / \mathrm{l}$ of carbonate, 16 are water in which sodium greatly predominates over calcium.

In the special types of ground water, the bicarbonate and carbonate contents differ from those in the prevalent ground water. The carbon dioxide charged waters (analyses 3 and 4) at Klickitat Springs have bicarbonate concentrations as great as 1,060 $\mathrm{mg} / \mathrm{l}$. The chloride-rich connate waters rising up into the basalt in western Oregon (analyses 326 and 444) have insignificant amounts of bicarbonate. Bicarbonate is low in the warm ground waters and is entirely lacking in the Union Hot Springs (analysis 483). Two analyses of the newly recharged ground water in the Columbia Basin Irrigation Project (analyses 120 and 261) show 
176 and $566 \mathrm{mg} / \mathrm{l}$ bicarbonate respectively. In these samples of recharge-modified ground water, the concentration of bicarbonate, in milligrams per liter, is less than the sulfate concentration but greater than the chloride concentration in analysis 120 and a little larger than the combined values for sulfate and chloride in analysis 261 .

\section{Sulfate}

In the natural ground water of the basalt, sulfate occurs within the extremes of $1-130 \mathrm{mg} / \mathrm{l}$ and within a common range of $10-50$ $\mathrm{mg} / \mathrm{l}$; it averages about $20 \mathrm{mg} / \mathrm{l}$. Some of the analyses show that relatively large amounts of sulfate are present in scme of the shallower aquifers beneath the synclinal basins (analyses 371 and 384), but that occurrence is not consistent. There seems to be no relation between the amount of sulfate in the natural ground water and the predominance of calcium or scrium, and it does not have a consistent relationship to the $\mathrm{pH}$. The ground water in the basalt west of the Cascade Range is mar'redly lacking in sulfate compared with that beneath the drier areas to the east.

As is common with the first flushing of accumulated salts from the soils of semiarid basins, the local recharge of grourd water as a result of deep escapement of irrigation water since the start of irrigation in 1952 has greatly increased the sulfate in the ground water of some parts of the Columbia Basin Irrigation Project (analyses 89,120,151, and 261). These newly recharged waters also have more calcium, sodium, and chloride (analyses 89, 120, 151 , and 261) than the prevalent ground water.

The source of the sulfate in the prevalent ground water of the basalt could be from the small amounts of sulfate dissolved during the oxidation of iron sulfide in the upper parts of the basalt where oxygen is more available, from the release of sulfur during the breakdown of other minerals and glass of the basalt, or from sulfur-bearing minerals in the soils and overburden through which water passes on its descent to the ground water. The general uniformity between the amount of sulfate in the deep and shallow ground water of the basalt and the general absence of sulfate beneath the humid areas west of the Cascade Range, where evaporite concentrations at the surface are negligible, seem to indicate that leaching from the soils and overburden yields most of the sulfate in the ground water of the basalt.

Among other special types of ground water, the hot water at Union Hot Springs is a sodium chloride water (anclysis 483) having $56 \mathrm{mg} / \mathrm{l}$ of sulfate, and the warm water at Bingham 
Springs is a sodium chloride water (analysis 364) having little sulfate. Neither the carbon dioxide charged waters near Klickitat Springs (analyses 3 and 4) nor the partly connate high crloride waters rising into the basalt of western Oregon (analyses 444 and 488, Hart and Newcomb, 1965) contain much sulfate.

\section{Chloride}

The prevalent type of ground water contains only small amounts of chloride, the total range being from 1 to $50 \mathrm{mg} / \mathrm{l}$. Most determinations fall between 5 and $30 \mathrm{mg} / 1$, and the average is abrut $10 \mathrm{mg} / \mathrm{l}$. Because of the lack of a source of chloride ions in the basalt, chloride is so uncommon that analyses with more than 30 $\mathrm{mg} / \mathrm{l}$ indicate distinctive ground water. The largest group of analyses showing more than $30 \mathrm{mg} / \mathrm{l}$ chloride is on ground water at rather shallow depth beneath semiarid basins of eastern Washington where recharge water apparently picks up chloride from evaporite concentrations in the soils and overburden (analyses 42,165 , and 212). This special type of ground water, newly recharged in the Columbia Basin Irrigation Project, contains up to $147 \mathrm{mg} / \mathrm{l}$ (analyses 92,120 ). The hot water at Union Hot Springs (analysis 483 ) has $129 \mathrm{mg} / \mathrm{l}$ of chloride. Waters hav'ng the highest chloride contents are the calcium sodium chloride waters rising into the basalt west of the Cascade Range. These waters may contain several hundred milligrams per liter of crloride (analyses 300-302 and 432), or, in extreme situations (anclysis 326 ), the chloride content may approach that of the saline water in the underlying sedimentary rocks.

\section{MINOR IONS OF MOSTLY ANION REACTION}

In the prevalent ground water, the combined content of fluoride, nitrate, phosphate, and boron amounts to less than $5 \mathrm{mg} / \mathrm{l}$, although in some areas the nitrate varies greatly and is more tran a minor anion. Also, even though the quantity is small some of these ions can be of great importance to the health of plants and animals using the water.

\section{Fluoride}

The total range of fluoride is from 0 to $2 \mathrm{mg} / \mathrm{l}$; an exceptionally great concentration is exemplified by one water sample (analysis 54) from well 12/29-28L1 north of Pasco which contained $4.7 \mathrm{mg} / \mathrm{l}$ in one of three analyses. The common range of fluoride, which doesn't vary geographically, is from 0.2 to about $0.8 \mathrm{mg} / \mathrm{l}$. The higher part of the total range, from 0.7 to $2 \mathrm{mg} / \mathrm{l}$, occurs in the sodium bicarbonate ground water that is in the synclinal basins of eastern Oregon and Washington. Analyses of 
the prevalent type of ground water from 58 sources show $1 \mathrm{mg} / 1$ or more fluoride; of these, 56 also show a predominance of sodium over calcium, in milligrams per liter. The two exceptions (analyses 135 and 466 ) have calcium exceeding sodium in ratios of only $24: 22$ and $26: 22 \mathrm{mg} / \mathrm{l}$. The basinal areas along the eastwest The Dalles-Umatilla syncline in south-central Washington and north-central Oregon and the structural sag running south from near Ephrata to Wallula in central Washington (Newcomb, 1970) are the main localities of this sodium fluoride ground water.

Of the special types of ground water, the saline connate waters that rise into the basalt at places in western Oregon contain relatively small amounts of fluoride, as do the newly recharged ground waters of the Columbia Basin Irrigation Project. The warm and hot waters of springs and wells contain above-average amounts of fluoride, and the carbon dioxide charged water neal Klickitat Springs in two analyses contain both average and above-average amounts of fluoride.

La Sala and Doty (1971) reported chemical analyses for water in the basalt and interbedded sedimentary layers at depths of 3621,200 feet and for water in basalt aquifers at intervals from a depth of 1,200-4,283 feet in the Atomic Energy Commission's deep exploratory well ARH-DC-1, located in the Cold Creek syncline northwest of Pasco (in sec. 35, T. 13 N., R. 26 E.). A study of the 18 analyses listed by La Sala and Doty (p. 50) indicates that the waters are similar to the sodium-rich type of the prevalent ground water of the basalt except for the high fluoride concentrations reported for most of the water-bearing zones below a depth of 726 feet. These high fluoride concentrations range from 2.0 to 21 $\mathrm{mg} / \mathrm{l}$ and are mostly in the $10-$ to $20-\mathrm{mg} / \mathrm{l}$ range in the water samples taken between 720 and 4,283 feet in depth. The well was drilled by air-rotary methods; water and detergents vere added to the air stream. Supposedly any contaminants were cleared from the well before the samples were taken, and some of the samples were believed by La Sala and Doty (p. 51) to have been uncontaminated; consequently, there may be a possi ility that such high-fluoride ground water occurs in the basalt at depths below 1,000 feet at some places. All evidence for such an occurrence is limited to the La Sala and Doty (1971) data.

\section{Nitrate}

Nitrate occurs within a common range of $0.2-6 \mathrm{mg} / \mathrm{l}$, and most of the analyses show less than $2 \mathrm{mg} / \mathrm{l}$. The total range runs from 0 to $99 \mathrm{mg} / \mathrm{l}$. Almost all the sources showing more than $10 \mathrm{mg} / \mathrm{l}$ are from wells that are less than 400 feet deep, as shown in figure 
4. Most of these waters having more than $10 \mathrm{mg} / \mathrm{l}$ of nitrate also have calcium predominating over sodium, as shown in figur? 5 .

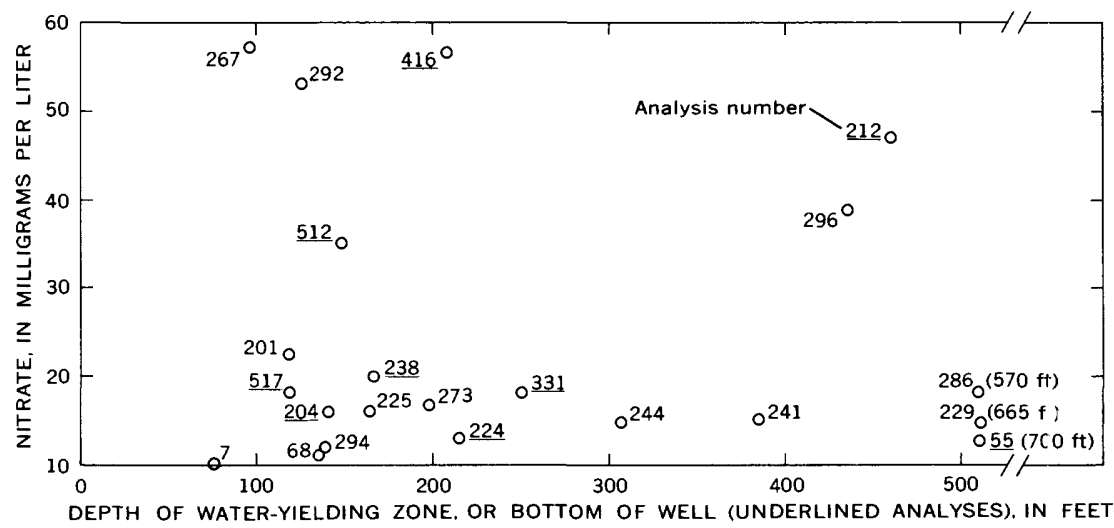

Figure 4. - The relation of depth of the water-yielding zone to the amount of nitrate, for analyses having $10 \mathrm{mg} / \mathrm{l}$ or more nitrate, in the prevalent type of ground water.

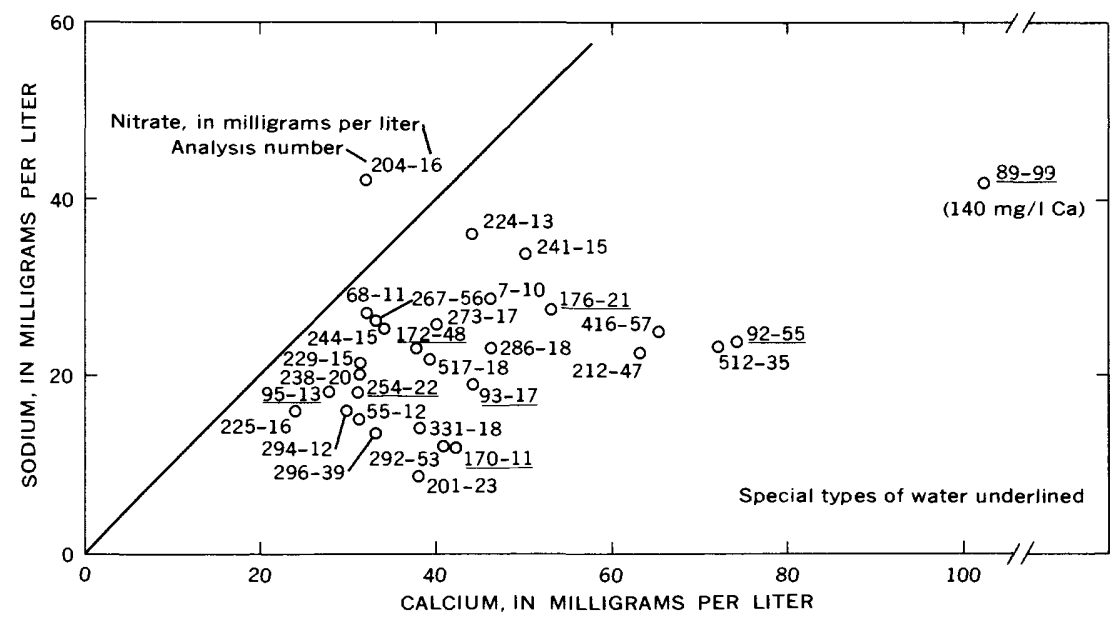

Figure 5. - The general predominance of calcium over sodium in the gr ound water having $10 \mathrm{mg} / \mathrm{l}$ or more of nitrate.

Many of the analyses having more than $20 \mathrm{mg} / \mathrm{l}$ nitrate are on the special type of ground water that is being artificially recharged by irrigation water (analyses such as 92 and 177). Three other special types of ground water - the carbon dioxide charged waters, the hot springs, and the high chloride waters west of the Cascade Range - do not show more than a few tenths of a milligram per liter of nitrates. 
The source of the nitrate, where there is more than about 2 $\mathrm{mg} / \mathrm{l}$, seems to be leached evaporite minerals, nitrogen fertilizer chemicals, or soluble organic materials between the surface and the aquifers.

The U.S. Public Health Service (1962, p. 78) fixed a limit of 45 $\mathrm{mg} / \mathrm{l}$ for nitrates in public water supplies and stated (p. 48) that nitrates in excess of $50 \mathrm{mg} / \mathrm{l}$ may give rise to infantile methemoglobinemia. Three private wells yield water that exceeds $50 \mathrm{mg} / \mathrm{l}$; two of these wells (analyses 267 and 292) draw water from permeable zones within 100 feet of the surface and one (analysis 416) is cased to only 60 feet.

\section{Phosphate}

The content of phosphate ranges from 0 to $2.8 \mathrm{mg} / \mathrm{l}$ and has a common range between 0.02 to $0.30 \mathrm{mg} / 1$ for the 138 determinations given in table 1 . There is no evident correlation between geologic or geographic differences among the sample sources and the higher or lower amounts of phosphate.

\section{Boron}

Determinations of boron are given (table 1) for 111 samples, and the analyses show a range from 0 to $10 \mathrm{mg} / \mathrm{l}$. Only 14 of those analyses show more than $0.20 \mathrm{mg} / \mathrm{l}$. From the few analyses for boron, no geographic distribution is apparent. The concantrations exceeding $1 \mathrm{mg} / \mathrm{l}$ are in the special types of ground water. Boron content is higher than $1 \mathrm{mg} / \mathrm{l}$ in the calcium sodium chloride water (analysis 326) which rises into the basalt west of the Cascade Range and is almost $2 \mathrm{mg} / \mathrm{l}$ in the ground water associated with intercalated sedimentary rocks in the Baker area (analrses 492493). By far the greatest concentration $(10 \mathrm{mg} / \mathrm{l})$ is in the warm water from Bingham Springs (analysis 364). Apparently, the presence of boron in concentrations ranging from a few hundredths to a few tenths of a milligram per liter is characteristic of the ground water in the basalt. The boron usually occurs in the small concentrations that are beneficial to plant growth when the water is used for irrigation. The amounts that might cause damage to crops irrigated with the ground water are present only in the above-mentioned special types of water.

\section{OTHER CHARACTERISTICS OF THE QUALITY OF THE GROUND GTATER}

\section{Dissolved Solids}

The prevalent type of ground water has total dissol"ed solids showing extremes that range from 68 to $568 \mathrm{mg} / \mathrm{l}$ and a common range of about $150-400 \mathrm{mg} / \mathrm{l}$. There is little evidence of a consistent variation of dissolved solids with depth, but there is some 
indication that the ground water occurring near natural recharge areas contains fewer total dissolved solids than does ground water in deep zones, remote from probable recharge areas. For example, the total dissolved solids in the Walla Walla Valley, close tc recharge areas in the Blue Mountains (analyses 9-27), average 180 $\mathrm{mg} / \mathrm{l}$ compared with $290 \mathrm{mg} / \mathrm{l}$ for wells in the flat-lying besalt north of Pasco (analyses 90-99).

As a rule, the special types of ground water carry more dissolved solids. The calcium sodium chloride water rising into the basalt of western Oregon has the greatest dissolved solids, $18,500 \mathrm{mg} / \mathrm{l}$ in analysis 326. One of the analyses of the carbon dioxide charged water (analysis 3) contains $950 \mathrm{mg} / \mathrm{l}$ dissolved solids. The warm and hot spring waters (analyses 364 and 483 ) are only moderately high in dissolved solids, 464 and $461 \mathrm{mg} / \mathrm{l}$ respectively ; the smaller amounts of dissolved solids have resulted partly from the loss of bicarbonate that has accompanied the temperature rise in these spring waters.

\section{Dissolved Gases}

The principal readily discernible dissolved gas is hydrogen sulfide, which occurs in small amounts in most of the ground water from wells in the basalt. It seems to be present in greatest amounts in the water from newly drilled wells. The consensus is that the gas diminishes with time as the well is pumped, rather than that the users become accustomed to it and notice it less with time. At some wells, where the gas is sufficiently strong, the owners find it desirable to lay a discharge line to their reservoir so that the water can be aerated before entering the pressurized system. Pumping directly into water mains, especially one incorporating a pressure tank, is objectionable because bubbles of the accumulated hydrogen sulfide gas can, at times, move out with the water flowing to users. No relations have been detected between the amount of this hydrogen sulfide in the water and the depth, the locatior. or the pressure of confinement of the water in basalt wells.

Carbon dioxide occurs in small quantities and rises freely from the ground water in springs and wells at Klickitat Springs, and possibly at other places. Thirty-eight analyses in table 2 show carbon dioxide concentrations that range from 0.01 to $50 \mathrm{mg} / \mathrm{l}$. A small amount of free carbon dioxide is apparently in balance with the bicarbonate and other ions in most of the ground water. At Klickitat Springs, carbon dioxide rises along a fault and oc?urs with the ground water, greatly exceeding the level of saturation. It rises through the ground water and lies in permeable parts of the basalt above the water table. For about 40 years the carbon 
dioxide at Klickitat Springs has been collected at springs and wells for the manufacture of dry ice.

The concentration of dissolved oxygen is very low in most of the ground water. A number of determinations, for which no recorded data are available, are known by the author to have found no oxygen in ground water of the basalt when it was correctly sampled before surface or pump-column aeration. Four of five analyses listed in table 2 show that dissolved oxygen ranged from 0.2 to $5.3 \mathrm{mg} / \mathrm{l}$, but no descriptions of the techniques of sampling and analyzing these samples are available. The procedure followed in the analyses listed are known to have involved field sampling and later laboratory analysis; hence, some of the analyses may be assumed to have been made on water which had been aerated. Because most of the ground water is confined under pressure within aquifers that contain fresh, untarnished, and unoxidized iron pyrite and because of the reported determinations of no oxygen, it is assumed that the ground water of the basalt is largely devoid of dissolved oxygen. Oral reports of experimenters in water treatment and fish culture state that the water from basalt wells dissolves oxygen readily when aerated at the surface.

\section{Hardness}

The ground water ranges from soft to very hard, according to the scale used by the U.S. Geological Survey, which terms 0-60 $\mathrm{mg} / 1$ soft, $61-120$ moderately hard, 121-180 hard, and more than 180 very hard. The range of hardness in the analyses is $4-412 \mathrm{mg} / \mathrm{l}$ and an approximated common range is $50-250 \mathrm{mg} / \mathrm{l}$. In most of the waters sampled, the calcium and magnesium, compris ing essentially all the constituents that unite with soap to form insoluble compounds, are in balance with bicarbonate anions ; thus, the hardness is largely of the temporary type, meaning it can be $\epsilon^{\prime}$ iminated by boiling the water. The sulfate and chloride types of hardness, the types called permanent, are prominent in the prevalent type of ground water east of the Cascade Range only in a few widely separated places within basinal areas of southern Washington and northern Oregon.

There seems to be no consistent relation between the hardness of ground water and the depth of the aquifers within the basalt. The analyses show that the hardness of water varies somewhat from place to place and even from well to well within the same area and depth zone of the basalt. Of the analyses on four city wells of similar depth at Ritzville, one yields samples containing 280 and $304 \mathrm{mg} / \mathrm{l}$ hardness (analyses 211-212) and the other three have hardnesses of only 114, 114 and $119 \mathrm{mg} / \mathrm{l}$. Most of the water 
supplies used by cities and towns fall in the range of moders.tely hard water, about $80-120 \mathrm{mg} / \mathrm{l}$. Some of the softest water of the public supplies belongs to the towns and cities adjacent to ares.s of substantial natural recharge, such as the slopes of the Blue Mountains. The town of Elgin, northeast of La Grande, receives some of the softest water (analyses 323-324) which has only $20 \mathrm{mg} / \mathrm{l}$ of hardness. The sodium-rich ground waters of the synclinal basins contain some soft waters. Umatilla and Othello have some rells that yield particularly soft water.

The special types of ground water in the basalt include the very hard calcium sodium chloride water, the hard and very hard carbon dioxide charged ground water near Klickitat Springs, and soft sodium water in or near warm and hot springs of northeastern Oregon.

\section{pH}

The $\mathrm{pH}$ of the prevalent type of ground water ranges from 6.5 to 9.2 on the commonly used scale for which 7 is the neutral roint at which neither acid nor alkaline conditions exist in the water. Most of the values fall between 7.2 and 8.4 and show that a slightly basic condition exists in the ground water of the basalt. The median point, 7.8, of the common range seems to be about the average $\mathrm{pH}$ condition. The sodium-rich water of The Dalles-Umatilla syncline (as shown by analyses $372-380$ ) has a pH range of 8.2-8.5.

Of the special types of ground water, the carbon dioxide charged water near Klickitat Springs has the lowest $\mathrm{pH}$, the two values being 6.4 and 6.6. The calcium sodium chloride water west of the Cascade Range shows low $\mathrm{pH}$ (6.2 in analysis 326$)$, high $\mathrm{pH}(9.6$ in analysis 444), and intermediate conditions (8.0 in analysis 453). The hot springs water (analysis 483 ), in which much of the bicarbonate has been converted to carbonate by the near-boiling temperatures, has the next to the highest $\mathrm{pH}$ (9.5) listed in the analyses. The somewhat similar warm sodium chloride waters near Bingham Springs (analyses 364-365), though low in bicarbonate, have lower $\mathrm{pH}$ values (8.6 and 8.5).

\section{Sodium-Adsorption-Ratio}

A ratio, called SAR (sodium-adsorption-ratio), has replaced older concepts because it more closely approximates the adsorption of sodium by an average soil when a water is used for irrigation. The ratio is given by the following equation when ion concertrations are expressed in milliequivalents per liter:

$$
\mathrm{SAR}=\frac{\mathrm{Na}^{+}}{\sqrt{\frac{\mathrm{Ca}^{+2}+\mathrm{Mg}^{+2}}{2}}} .
$$


The total range of the SAR values for the prevalent ground water in the basalt (table 1 ) is from 0.2 to 19.6, and the common range is from 0.5 to 4.0. When the SAR and the specific conductance of a water are plotted on a diagram devised by the U.S. Salinity Laboratory Staff $(1954$, p. 80), as in figure 6, approximate salinity and sodium (alkali) hazards are obtained for irrigation use of water on a soil that is assumed to be average. The p'ntting of representative analyses (fig. 6) shows that the prevalent ground waters fall in classes $\mathrm{C} 1-\mathrm{S} 1$ and $\mathrm{C} 2-\mathrm{S} 1$, which represent low and medium salinity hazard and low alkali hazard. The only waters that show characteristics classed as hazardous to irrigation use are among the special types of ground water. One analysis of a special type of ground water, the calcium sodium chloride water in parts of western Oregon, is shown by the plotting (fig. 6) to be very high in both salinity and alkali hazards. In analys?s of two other special types of ground water, those of areas artificially recharged with lost irrigation water and that from one rot spring fall in positions intermediate between the safe water and the hazardous waters (fig. 6).

Specific Conductance

The analyses of table 1 give a total range of specific electrical conductivity from 107 to 694 micromhos and a common range of 200-500 for the prevalent type of ground water. In general, the low specific conductance expresses the low concentration of dissociated ions (all ions except the silica). The special type of ground water resulting from recent artificial recharse of the Columbia Basin Irrigation Project has specific conductance ranging from about 700 to as much as 1,820 (analysis 261), and the calcium sodium chloride waters have a conductance as high as 29,600 micromhos (analysis 326). When plotted against the SAR (as in fig. 6), the specific conductance, by expressing tre amount of chemically active dissociated ions, helps to indicate tre salinity and alkali hazards of the ground water used for irrigation.

\section{Trace, or Minor, Constituents}

The analyses for lithium, strontium, barium, chromium, copper, lead, nickel, titanium, vanadium, arsenic, and a few other minor elements in the ground water are given in table 2. Most of the values for the first nine ions listed above were taken frcm Adams $(1957,1960)$, and most of the arsenic analyses were by the Oregon Board of Health. Minor elements constitute less tlan a few milligrams per liter of the total dissolved solids found in the analyses.

Chromium determinations had a maximum of $0.03 \mathrm{mg} / \mathrm{l}$, well below the limit of $0.05 \mathrm{mg} / \mathrm{l}$ recommended for domestic use in 


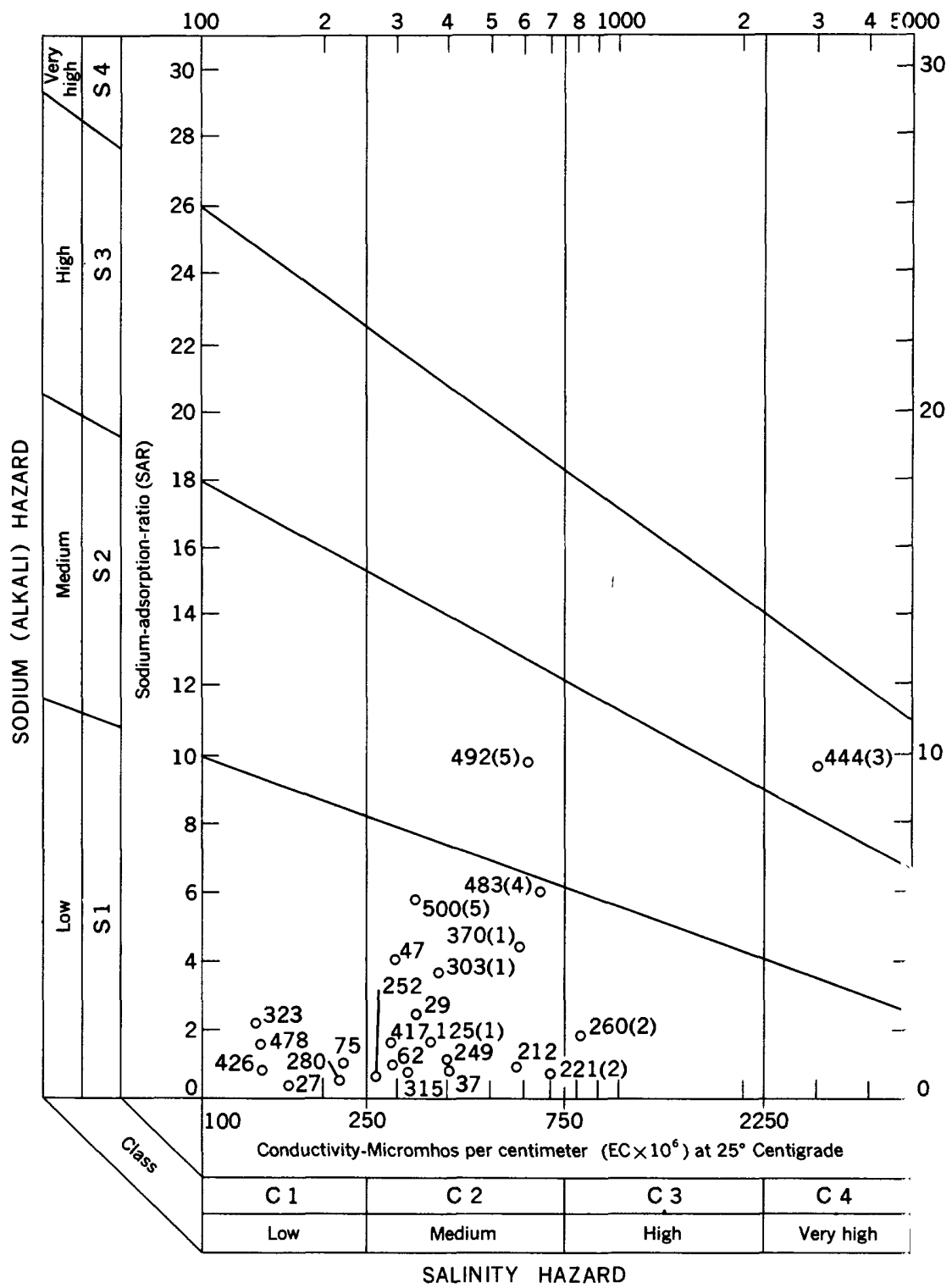

FIGURE 6. - Plot of SAR and specific conductance for 18 representrtive analyses of the prevalent ground water and six analyses of special t:pes of ground water. Numbers in parentheses indicate (1) high sodium, prevalent ground water, (2) artificially recharged ground water, (3) calcium sodium chloride water west of the Cascade Range, (4) hot-spring water, and (5) ground water in an area where much sedimentary materirl is interbedded with the basalt. 
the standards of the U.S. Public Health Service (1962). Lead was analyzed in four samples, the greatest of which amounted to $0.022 \mathrm{mg} / \mathrm{l}$, also well below the recommended limit of $0.1 \mathrm{mg} / \mathrm{l}$. Arsenic values in 15 analyses were less than $0.005 \mathrm{mg} / 1$ except one, which was listed as $0.005 \mathrm{mg} / \mathrm{l}$; these values are one-tenth, and less, of the recommended limit of $0.05 \mathrm{mg} / \mathrm{l}$.

Barium was in all the ground-water samples for which it was analyzed. In only one sample, from a well at Pomeroy where 2.23 $\mathrm{mg} / \mathrm{l}$ was found, was the content reported to be more than 0.10 $\mathrm{mg} / \mathrm{l}$. A limit of $1 \mathrm{mg} / \mathrm{l}$ is recommended by the U.S. Public Health Service (1962, p. 28).

Strontium was present in small amounts in all 65 analyses for which determinations were listed; in only five of these analyses was it greater than $1 \mathrm{mg} / \mathrm{l}$. These five analyses on water from five wells south and west of Portland gave values ranking from 1.2 to $28 \mathrm{mg} / \mathrm{l}$. Two of these well waters are the calcium sodium chloride type that rise into the basalt in parts of that area.

Lithium content was determined for only three samples, all from Ephrata, and the three analyses range from 0.02 to 1.77 $\mathrm{mg} / \mathrm{l}$.

\section{Radioactivity}

The 27 analyses of table 3 include determinations of g"oss betagamma activity in micromicrocuries per liter $(\mu \mu \mathrm{c} / \mathrm{l})$, radium in micromicrocuries per liter, and uranium in micrograms per liter $(\mu \mathrm{g} / \mathrm{l})$. The analyses (samples $38,43,59,61$, and 63 ), made before 1952, determined the gross beta-gamma activity, radium, and uranium down to cutoff points that were, respectively, 100, 10, and 1,000 times larger than the cutoff points used as minimum measurable amounts after 1955 .

The 21 analyses carried to the accuracy of the post-1952 measurements show maximum beta-gamma activity of $32 \mu \mathrm{uc} / \mathrm{l}$, indicating that the greatest radioactivity of water samples was far below the gross beta-activity safety limit of $1,000 \mu \mu \mathrm{c} / \mathrm{l}$ for public water supplies, as set by the U.S. Public Health Service $(1962$, p. 9). Twenty-two post-1951 analyses show the maximum radium content to be $0.6 \mu \mu \mathrm{c} / \mathrm{l}$ and the maximum uranium content to be $10 \mu \mathrm{g} / \mathrm{l}$. The radioactivity of the ground waters of the basalt is low, in keeping with the low range of radioactivity common to basaltic rocks.

\section{PHYSICAL CHARACTERISTICS COLOR}

Of the 201 determinations of color listed in table 1, 95 give a 0 value, and the greatest is 20 on the scale for which 500 is the 
top, or mostly opaque, standard. The ground water of the basalt is customarily clear and devoid of coloring matters in solution. Sediment or suspended matter in the ground water taken from wells and springs is usually due to inadequate casing which admits material from overlying or interbedded sedimentary formations, from entrainment of materials deposited on the casing and pump, or from the precipitation of small amounts of dissolved materials like iron oxide; this type of cloudiness is lacking in the water from adequately constructed and operated wells.

\section{TEMPERATURE}

In general, the temperature of the ground water is a few degrees higher than the sum of mean annual temperature of its area and the temperature increase due to the earth's thermal gradient down to the aquifer in which the water occurs. T.ere are many variations from this generalization; some of the grcind water is much warmer, and some is cooler than would be experted from the "normal" thermal gradient which is considered to b? an increase of $1^{\circ} \mathrm{C}$, or $1.8^{\circ} \mathrm{F}$, for each 100 feet of depth beyond the top 100 feet. Each of the Celsius (centigrade) values in table 1 can be converted to the more familiar Fahrenheit scale by multiplying by 1.8 and adding 32 .

Just over half the analyses in table 1 include water temp?ratures. Supposedly, these temperatures were recorded at the time of sampling in all cases. However, interaquifer circulation in certain wells had preceded the sampling, so a few of the temporatures listed may not be correct for the ground water in the aquifers to which it is assigned. Some of the multiple analyses on single wells have temperatures that differ by several degrees. For example, analyses 20 and 21 (well $7 / 36-22 \mathrm{~N} 1$ at Walla Walla) have a temperature difference of $2.9^{\circ} \mathrm{C}\left(5^{\circ} \mathrm{F}\right)$, whereas, analyses 133 and 134 (well 15/45-32N1 at Pullman) show a temperature difference of $6.1^{\circ} \mathrm{C}\left(11^{\circ} \mathrm{F}\right)$.

It has been the author's experience that nonrepresentative temperatures can be observed for ground water through one or both of two types of error involving improper techniques and inadequate samples. The proper technique requires a car $\because u l$ measurement of water temperature at the well and a large sample, preferably a sustained pump discharge. The useful samplo is one large enough to represent conditions in the aquifer. Obtaining true samples from each aquifer of a multiaquifer well can be a formidable task. Apparent discrepancies in the records notwithstanding, the general nature of the temperatures of the ground water can be approximated from the data in table 1 . 
The temperatures of the prevalent type of ground water range from $8.9^{\circ} \mathrm{C}\left(48^{\circ} \mathrm{F}\right)$ to $30^{\circ} \mathrm{C}\left(86^{\circ} \mathrm{F}\right)$. These extremes, respectively, are on water from a 213-foot well south of Davenport (analysis 273) and a 1,150-foot well near La Grande (analysis 443). The coolest item of this range is only a degree or so less than the mean annual temperature; this is common in the uppermost 100 feet of the earth. If the ground water comes from the lowest part of the well, $1^{\circ} \mathrm{C}\left(1.8^{\circ} \mathrm{F}\right)$ should be added to the me?n annual temperature for the additional depth to 200 feet. However, the upper item of the temperature range, $30^{\circ} \mathrm{C}\left(86^{\circ} \mathrm{F}\right)$, is $11^{\circ} \mathrm{C}$ $\left(19^{\circ} \mathrm{F}\right)$ above the $9.7^{\circ} \mathrm{C}\left(49.4^{\circ} \mathrm{F}\right)$ mean annual temperature at La Grande plus $10^{\circ} \mathrm{C}\left(18^{\circ} \mathrm{F}\right)$ for 1,000 feet of depth. This is the general situation for deeper ground waters-locally the temperature is higher than the depth alone would indicate it should be. Areas within which the deeper ground waters are warmer than normal earth temperatures have been noted at the southeast side of Walla Walla, at places in the Quincy Basin southwest of Ephrata, and at The Dalles (Newcomb, 1959, p. 16) ; also, they have been observed in the Grande Ronde Valley near La Grande (Hampton and Brown, 1964, p. 44) and in the Umatilla River basin (Hogenson, 1964, p. 54-56). Hogenson (1964, p. 55) concluded that the data on wells near Pilot Rock, 13 miles south of Pendleton, indicated a temperature increase of at least $2^{\circ} \mathrm{F}$ per 100 feet of depth below the first 100 feet of the basalt.

The ground water having higher-than-normal temperature near The Dalles occurs in structural compartments, each of which has rather distinct temperatures. The "Mill Creek artesian aquifer," which ranges in depth from 300 to 800 feet, has $27.8^{\circ} \mathrm{C}\left(82^{\circ} \mathrm{F}\right)$ water (analysis 303) and extends downvalley for several miles to a terminating fault barrier. The same water-bearing stratum northeast of that barrier contains water whose pressure level stood 600 feet lower; this lower pressure water has a temperature of $21-22^{\circ} \mathrm{C}\left(69-72^{\circ} \mathrm{F}\right)$, still nearly $8.3^{\circ} \mathrm{C}\left(15^{\circ} \mathrm{F}\right)$ above the normal thermal gradient for its 200- to 300-foot derth (Newcomb, 1969, p. 26).

The hot spring (analysis 483) and some of the warm waters analyses 3 and 364) occur near faults through which water or gas from greater depths may bring excess heat. Also, the ground water near known faults, some of which are g?ologically young, is commonly warmer than the normal thermal gradient would allow, leading one to believe that the pickup of heat from zones of mechanical rupture or the ascent of ground water from deeper and warmer zones are possible explanations of the excess heat. Because young volcanic rocks of Pleistocene and Holocene 
age occur in and adjacent to the Cascade Range and also in small areas scattered across northern Oregon, local areas of volcanic heat cannot be ruled out as sources of the elevated temperature of some of the warmer ground water. However, in the deeper ground waters, the widespread occurrence of a few degrees of temperature above that of the normal thermal gradient indicates that a higher-than-average thermal gradient exists in the basalt, as suggested by Hogenson (1964).

Within and adjacent to some of the areas of generally warmer deep water, there are aquifers whose water shows normal earth temperatures and some whose water is several degrees cooler than normal. Ground water that is a few degrees cooler than the normal temperature occurs in the basalt around the edges of some of the downwarped basins and is commonly attributed to the rapid descent and lateral movement of cooler water from the surface.

\section{EFFECT OF TIME ON THE QUALITY OF THE GROUND WATER}

\section{AGE OF THE GROUND WATER}

Only a short time, geologically speaking, is required for the ground water of the basalt to acquire the dissolved constituents found by the first well and spring users. As ground water is withdrawn from the aquifers, other water moves into the gro'indwater reservoir and ultimately reaches the exit points. This irflux of new water causes changes in the chemical quality of the water withdrawn from some wells.

The ground water now being withdrawn from wells drilled in newly developed ground-water areas is a composite from many different, largely natural, recharge events. In areas of greater pumpage and of long-term ground-water withdrawal, some of the more permeable aquifers may contain ground water which is a mixture of the old water and that newly drawn into the aquifer. These composite waters have average ages that show they have been underground for various periods, ranging from a few years to several tens of thousands of years.

Water samples taken from three different depth zones of the basalt within The Dalles-Umatilla syncline in northern Oregon were dated with carbon-14 in the Geological Survey Isotope Laboratory as follows (Robison, 1970) : 


\begin{tabular}{|c|c|c|c|c|}
\hline Owner & Well No. & $\begin{array}{l}\text { Depth } \\
\text { of zone, } \\
\text { in feet }\end{array}$ & $\begin{array}{l}\text { Laboratory } \\
\text { No. }\end{array}$ & Age, in years \\
\hline 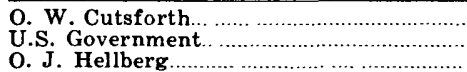 & $\begin{array}{r}1 / 26-1 \mathrm{~J} 1 \\
4 \mathrm{~N} / 27-8 \mathrm{R} 1 \\
3 \mathrm{~N} / 26-5 \mathrm{M} 1\end{array}$ & $\begin{array}{c}30-70 \\
256-453 \\
1200-950\end{array}$ & $\begin{array}{l}W-2112 \\
W-2090 \\
W-2092\end{array}$ & $\begin{array}{c}\text { Modern } \\
6,700 \\
\mathbf{2 7 , 2 5 0}\end{array}$ \\
\hline
\end{tabular}

'Zone is uncased, but the main water is believed to enter from the lower part.

Carbon-13 determinations of these ages showed the original source of the carbon in the carbonate ions to be the atmosphere, not carbonate minerals of the rocks traversed by tle water. The stratigraphic manner in which the ground water occurs in these three wells is illustrated in the geologic section (fig. 7).

A water sample from an aquifer in the depth zone. 540-620 feet of the deep test ARHDC-1, located within the Cold Creek syncline in sec 35, T. 13 N., R. 26 E., on the Hanford Reservation of the Atomic Energy Commission, was dated in the Radiocarbon Dating Laboratory of the University of Texas in 1969 as 13,000 years before the present (La Sala and Doty, 1971, p. 53). From age determinations on 44 samples of ground water from wells in eastcentral Washington, Jan Silar (1969) concluded that the ages of the ground water in the top few hundreds of feet of the basalt ranged from 0 to $16,275 \pm 1,465$ years before the present. The ages of the bulk of the determinations were between 0 and 6,000 years. The depth of the aquifers sampled ranged from 21 to 607 feet, only one sample (from the 600-foot level) being frcm deeper than 300 feet. No significant correlations between age $\varepsilon$ nd depth or age and aquifer were derived from Šilar's publication.

Age dates were obtained by Crosby and Chatters (1965) on 33 samples of ground water taken from wells in the basalt at Pullman and Moscow, in addition to seven other wells in losss and a residual weathering zone of older rocks and sedimentary deposits. The carbon-14 ages of the ground water in the basalt ranged from 1,685 to $\geqslant 32,000$ years. An appraisal of their data indicates that age may increase downward, roughly correlating with depth, but there are many exceptions to this relation. It is possible that most of the exceptions to this inferred correlation of age to depth occur within two depth zones where the aquifers have received substantial additions of younger water which was drawn in as a result of the large pump withdrawals from those aquifers during the last 60-80 years. When the data on the samples taken from the two areas (Pullman and Moscow) are plotted separately, on graphs that show the age of the water versus the altitude of the aquifer, the exceptions to the general trend of increasing age with depth are shown to be explainable by the above hypothesis (figs. 8 and 9). 


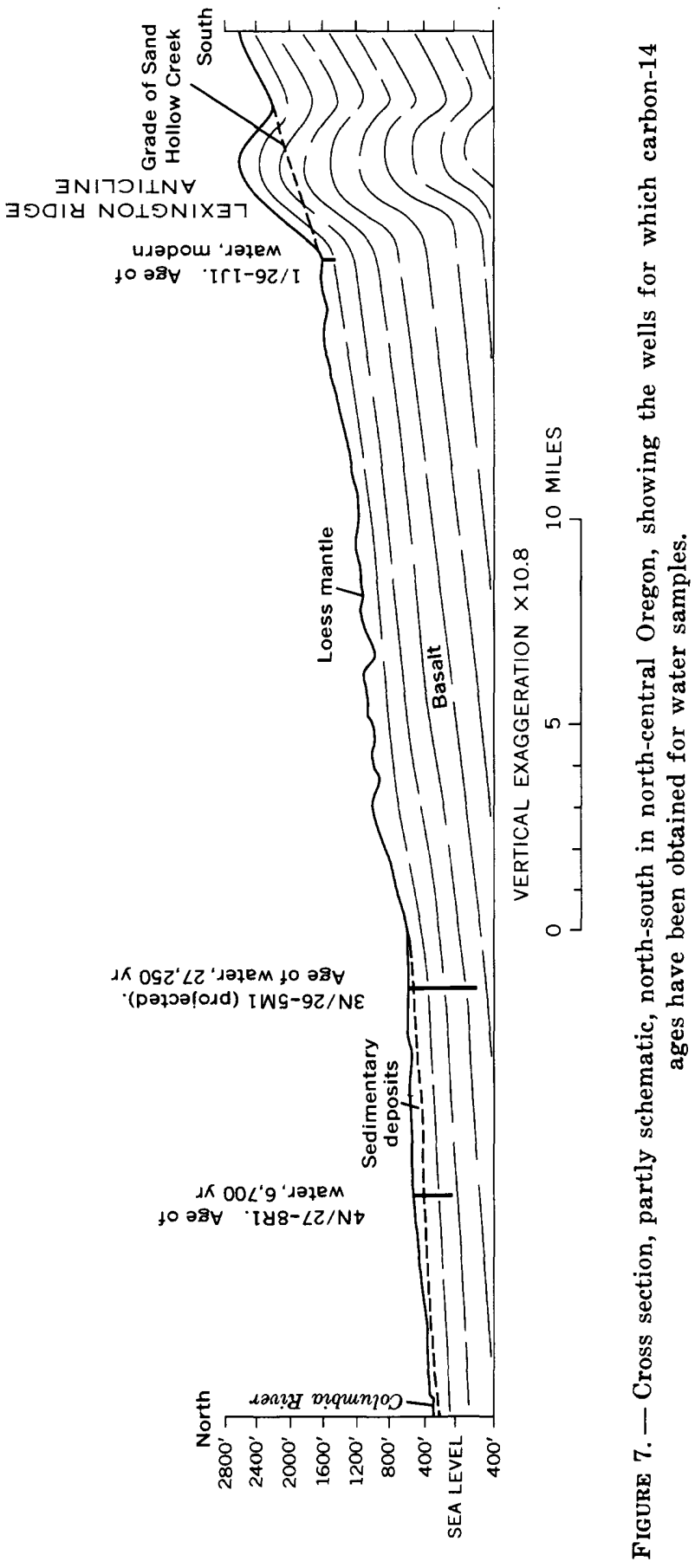




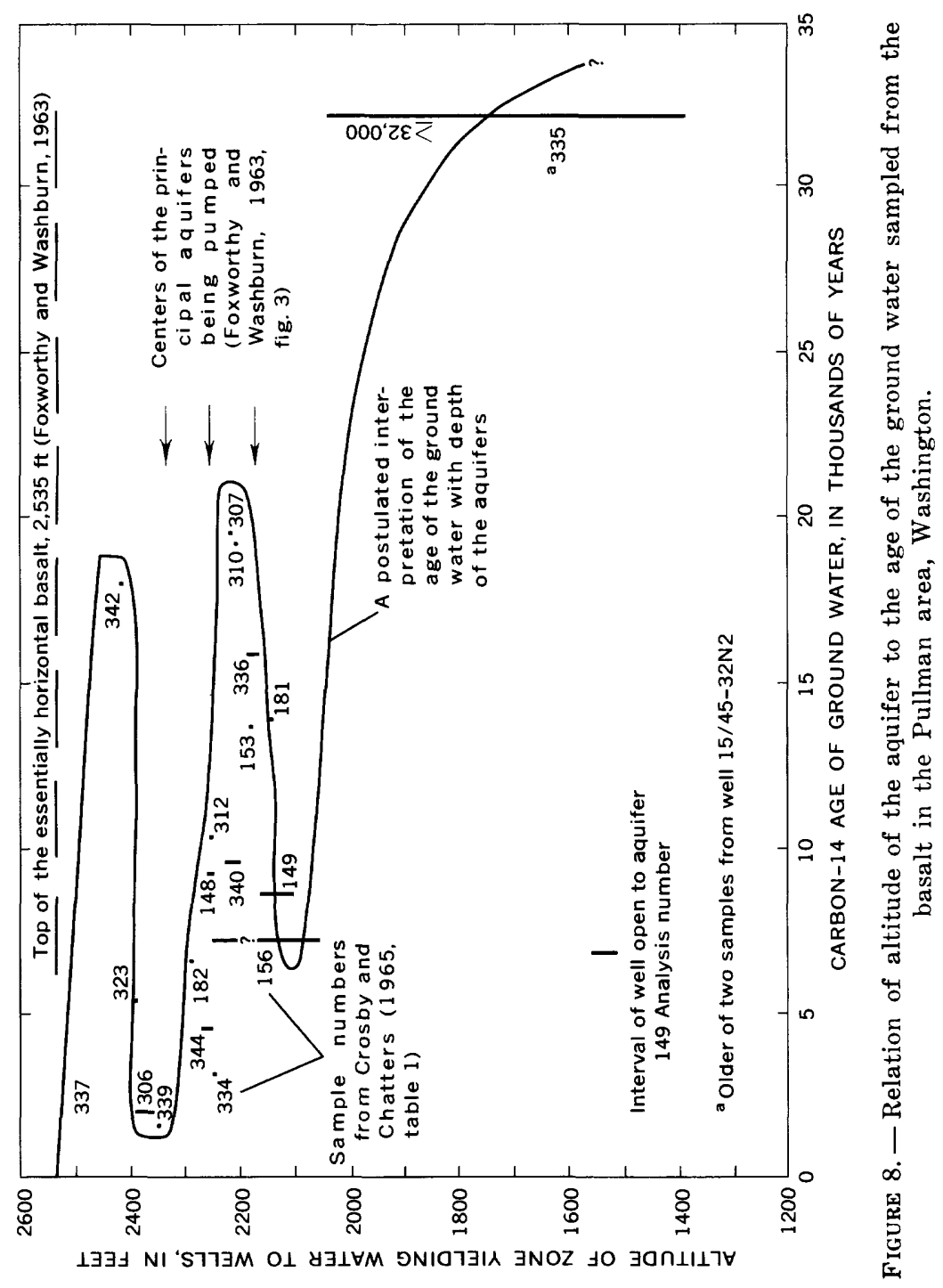




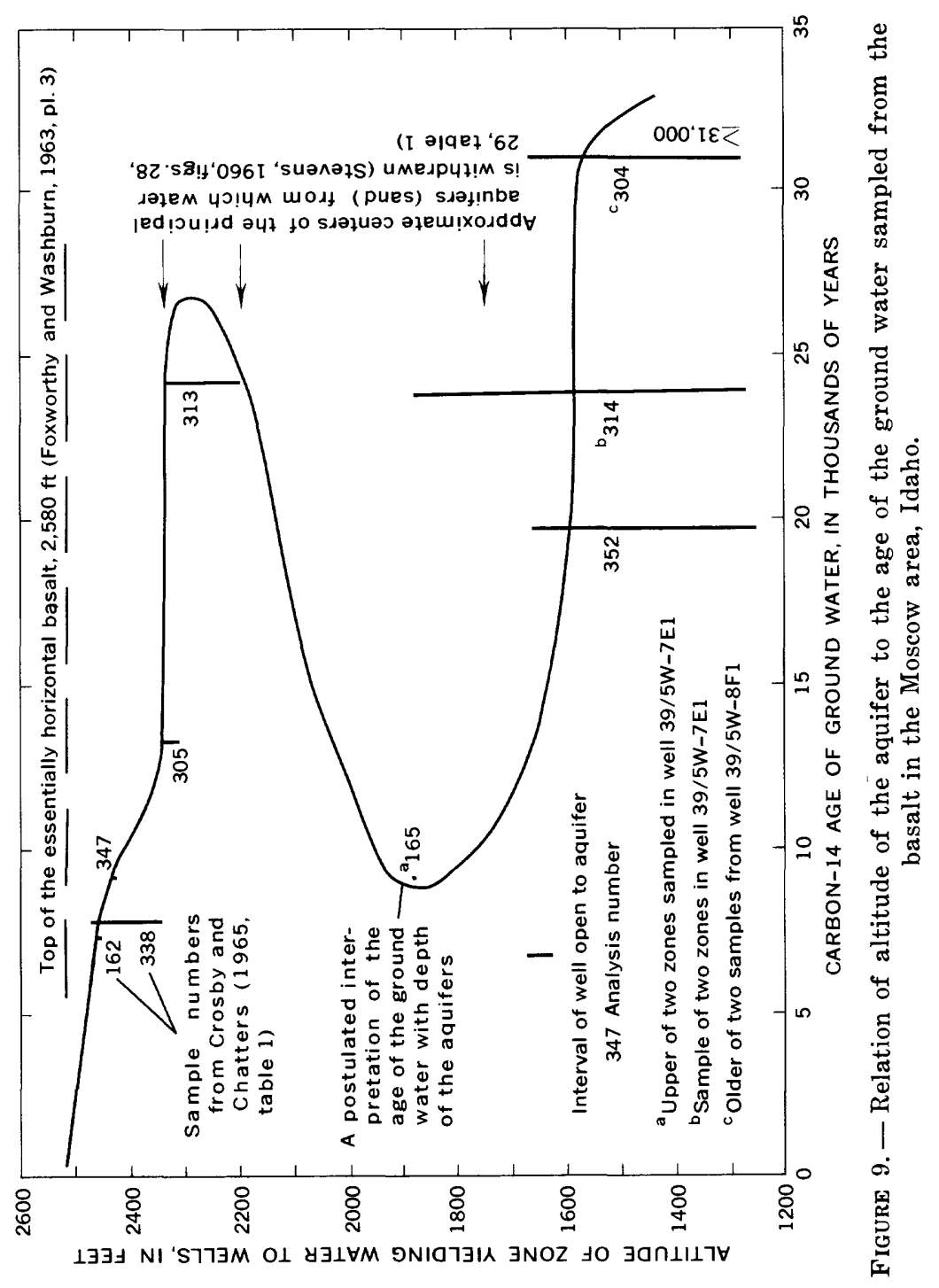


In addition to the age-depth relationships, some of the samples and age determinations of Crosby and Chatters (1965) may indicate other information about the ground water. Arnarently, water was being withdrawn from more than one aquifer in certain wells when some of the water samples were taken. For example, an age of 6,150 years was obtained in 1964 and $\geqslant 32,000$ years in 1965 on water from well $15 / 45-32 N 2$, the deep well of Pullman. This 954-foot well is cased to 399 feet, but its log contains no record of the type or tightness of the casing-to-rock seal and no record of the location of the water-bearing zone, or zones, below the casing. The differences in the two ages obtained on samples of water from this well could indicate that the water withdrawn comes from aquifers of different depths and may or may not be a mixture, depending on the extent and rate of presample pumping.

From the age data on hand and the knowledge of the recharge systems through which water has gained entry to the tabular aquifers in the basalt, it may be concluded that ground water of all ages, from modern times to many tens of thousands of years, is to be expected in the basalt. Patterns of the basic circulation routes of the ground water may be indicated when adequate data are at hand.

\section{RELATION OF AGE TO QUALITY}

A comparison of the ions in the three ground waters sampled by Robison for age determinations (analyses 437, 381, 361) indicates some general differences that correspond to greater age of the water deeper underground. These analyses show that the water at greater depth has a lower content of calcium (43-9 $\mathrm{mg} / \mathrm{l})$, magnesium (17-3 $\mathrm{mg} / \mathrm{l})$, and bicarbonate $(226-176 \mathrm{mg} / \mathrm{l})$, and, correspondingly, a greater content of sodium $(24-57 \mathrm{mg} / \mathrm{l}$ inconsistently) and potassium (6-12 $\mathrm{mg} / \mathrm{l})$. There is an increase in the sulfate from $19 \mathrm{mg} / \mathrm{l}$ in the youngest water to $94 \mathrm{mg} / \mathrm{l}$ in the intermediate water, and then a decrease to 0.2 $\mathrm{mg} / \mathrm{l}$ in the oldest ground water. The total dissolved solids in water of the three wells differ mainly in accordance with the amount of sulfate - the total of the other ions being roughly similar in the three waters. On the basis of these anal'rses, the differences in ion concentrations could be attributed to slight differences in the chemical history of the three ground waters rather than to chemical changes that occurred in one uniform type of water while it was gaining greater depth or age. However, the small amounts of calcium and magnesium in the older 
sodium-rich ground water indicate that some depletion of magnesium, and probably of calcium, occurs, either by base exchange or by chemical precipitation.

\section{CHANGES IN QUALITY OF THE GROUND WATER AS RECORDED IN THE DATA}

\section{CHANGES INDICATED DURING ITS UNDERGROUND JOURNEY}

A history describing the chemical acquisitions of the ground water in the basalt can be reconstructed because of the fact that water, on the surface, has low ion concentrations and, while passing through sedimentary materials and soils that lie on the basalt, it acquires additional ions. The analyses below indicate that the ground water obtained some additional ions early in its traverse of the basalt aquifers as well. The result of the three acquisitions - on the surface, within the overburden, and within the basalt - resulted in the dissolved-solids load typical of the average native ground waters of the basalt. Analyses representing these three epochs in the simulated history of ground vater in the drier part of the basalt region follow. The data was selected and averaged from that given for the Walla V'alla Valley (Newcomb, 1965), Umatilla River valley (Hogenson, 1964 ; Santos, 1965), Upper Grande Ronde River valley (Hampton and Brown, 1964), and the Palouse River valley (Foxworthy and Washburn, 1963). There is some evidence that a similar threestage pickup of dissolved solids has also characterized the ground water in the basalt of the slightly more humid areas of the basalt region.

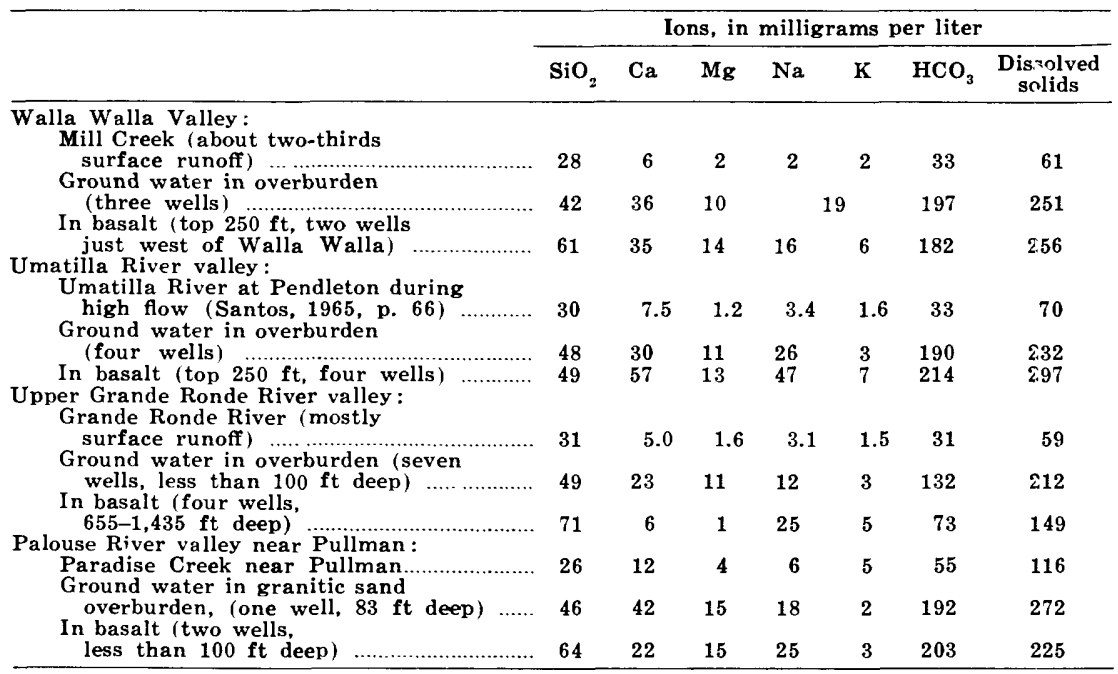


Despite the evidence that some of the dissolved materials were obtained before the water entered the basalt, much of the ground water has had at least many hundreds or thousands of years residence, as described previously, and is in gener 1 chemical equilibrium with the basalt. One analysis of water from the sandy deposits overlying the basalt in the Upper Grande Ronde River valley (Hampton and Brown, 1964) and many analyses given by Walters and Grolier (1960) for the Columkia Basin Irrigation Project area show that some of the ground water in the overburden of basin areas has a greater content of dissolved solids than does the ground water in the basalt below. This larger load of dissolved solids in ground water of the overburden may indicate that one or several of the following three conditions were operative: (1) The ground water entered the basalt beneath adjacent slopes where less sedimentary cover exists, has little dissolved matter from the overburden and was long isolated from the drainage of the overlying materials, (2) some of the ground water in the basalt percolated through the overburden in more humid times when the overburden contained a lesser amount of soluble salts, or (3) removal of ions from solution has oc?urred in the basalt.

CHANGES IN QUALITY OF THE GROUND WATER WITH TIME

Among the analyses listed in table 1 are many that were made on samples from the same wells over the span of a decrde; also, there are a few that were made on samples from the same wells over several decades. The longest period of time is covered by analyses 182-185 on samples taken from well 19/24-7J1 near Quincy (17 miles southwest of Ephrata) in 1916, 1950, 1960, and 1961.

The only changes that have occurred in the qualit: of the ground water within the period covered by the analyses are man made and consist of: (1) An increase in the concentrations of calcium, sodium and chloride at some pumped wells in water which rises into the basalt west of the Cascade Range, and (2) an increase in most of the principal ions in ground water near areas of artificial recharge from irrigation water in the Columbia Basin Irrigation Project area.

The increase in ionic concentrations in the calcium sodium chloride water is shown by analyses 453-456 on samples from two wells at Lake Oswego, southwest of Portland. Apparently the pumping of these wells induced the rise of a proportionately greater amount of saline ground water. The total thickness of the basalt of the Columbia River Group in that area is only 600- 
800 feet, and heavily pumped wells drawing water from the lower part of that basalt section are vulnerable to this change ir the quality of the water unless adequate means of natural recharge occur in that locality. Analyses 327 and 328 show that no such change has occurred in a well at North Plains, 20 miles northwest of Lake Oswego.

The general increase in most of the principal ions (particularly the sulfate, chloride, sodium, and calcium) in the ground vrater near areas of artificial recharge in the Columbia Basin Irrig tion Project is shown by analyses 118-120, 175-177, 220 and 221, and 254-256. That this increase in dissolved solids is not widespread in the project area is shown by the unchanged quality of the ground water of the basalt in series of analyses on other wells, such as analyses 227-230 and 231-234 for wells at Larsor Air Force Base.

Wells $14 / 30-8 \mathrm{G} 1$ and $14 / 30-20 \mathrm{~A} 1$, in areas of recharge from lost irrigation water, had a decrease in both sulfate and nitrate between 1958 and 1962. This decrease is indicated by the amounts shown in table 1 for 1958 (368 and 99, 93 and 55, the sulfate and nitrate from each of the two wells, respectively) as compar?d to the amounts (168 and 48, 56 and 30 ) found in partial analyses for June 1962, not shown in table 1 . A decline from the high sulfate and nitrate concentrations of 1958 may indicate that the main flush of salts had occurred and that subsequent concentrations of salts in the water of these wells would be lower.

Series of analyses over an expanse of several years show an increase of nitrates in the recharge-augmented ground water of some wells in the Columbia Basin Irrigation Project and of some of the wells at the Fairchild Air Force Base west of Spokane.

The water from most deep wells has remained rather constant in hardness during the long-term use, but a few changes $c f$ the hardness of water are shown in the data on table 1. Analyses 278-283 on water from one 410-foot well at Fairchild Air Force Base west of Spokane show a nearly constant hardness, ranging from 82 to $90 \mathrm{mg} / \mathrm{l}$ from 1947 to 1959 , and a rise in hardness to $125 \mathrm{mg} / \mathrm{l}$ accompanying an increase in calcium and a decrease in sodium in 1960 .

\section{SUMMARY}

The ground water native to the Columbia River basalt, as known from the more than 500 chemical analyses, has a moderate dissolved-solids content of about $275 \mathrm{mg} / \mathrm{l}$. Calcium, sodium, bicarbonate, and silica are the principal constituents of the dissolved solids in the prevalent type of water. 
The chemical nature of the ground water of the basalt is rather uniform throughout the 50,000 square miles of diverse topography, climate, and rock structure, but a few differences occur. Sodium-rich waters are characteristic of the synclinal basins east of the Cascade Range, sulfate is low or lacl-ing west of the Cascade Range, and chloride is lowest near recharge areas in mountain terrain. Only nitrate, which is greatest in wells less than 400 feet deep, seems to have a depth-of-aquifer relation. The chemistry of the prevalent type of ground water agrees with the general characteristics of ground water in basalt terranes as stated by Hem (1959, p. 203-207).

The prevalent type of ground water contains, on an average, $55 \mathrm{mg} / \mathrm{l}$ silica, $0.2 \mathrm{mg} / \mathrm{l}$ iron, $19 \mathrm{mg} / \mathrm{l}$ calcium, $8 \mathrm{mg} / \mathrm{l} \mathrm{m \varepsilon} \mathrm{gnesium,}$ $37 \mathrm{mg} / \mathrm{l}$ sodium, $7 \mathrm{mg} / \mathrm{l}$ potassium, $150 \mathrm{mg} / \mathrm{l}$ bicarbonate, $20 \mathrm{mg} / \mathrm{l}$ sulfate, $10 \mathrm{mg} / \mathrm{l}$ chloride, $0.5 \mathrm{mg} / \mathrm{l}$ fluoride, $1 \mathrm{mg} / \mathrm{l}$ nitrate, 0.15 $\mathrm{mg} / \mathrm{l}$ phosphate, and $0.1 \mathrm{mg} / \mathrm{l}$ boron. It has moderate hardness and a $\mathrm{pH}$ of 7.8. Water from some wells has a slight odor of hydrogen sulfide. Except for silica, the content of most of the dissolved elements varies with the predominance of other elements; for example, fluoride is generally greatest and magnesium is least in sodium-rich waters.

Special types of the natural ground water include: (1) Calcium sodium chloride waters that rise from underlying sedimentary rocks west of the Cascade Range, (2) mineralized water at or near warm or hot springs, (3) mineralized water at or near one carbon dioxide charged locality, and (4) water within or near sedimentary rocks at the edges of the basalt where unusual concentrations of ions, especially chloride, occur. In addition to the native or natural types, one artificially altered type, a sodium calcium sulfate chloride bicarbonate water has resulted where irrigation water recharged the ground water after passage through soils and sedimentary deposits. These five special types cf ground water contain the only water unsuitable for most ordinary uses; the calcium sodium chloride water in places reaches salinities that are undesirable for many common uses of water.

Carbon-14 dates of the ground waters range from 0 to equal to or greater than the 32,000-year limit of the dating process.

The temperature of the ground water is usually slightly higher than would be indicated by the normal thermal gradient, but exceptions to the rule, both warmer and cooler, occur. The warmest waters occur near the traces of faults, and several natural sources of the excess heat can be postulated.

The minor elements like lithium, strontium, the metals, vanadium, and arsenic occur in only trace amounts, and only one 
element (barium) in one analysis (table 2) surpasses the limits set in health standards. Radioactive elements are present in very small amounts.

The origin of the dissolved materials appears to lie primerily in the history of the water during its descent to the basalt and secondarily to the solution and exsolution of ions within the basalt.

According to standards set for most types of water use, the ground water is of excellent quality except for: (1) the generally high content of silica, forming scale on boilers, (2) the moderate hardness, (3) a small and variable iron content wrich, in places, needs removal for uses like laundering, (4) a slight hydrogen sulfide content which may need to be removed by aeration in some places and, (5) locally, at shallow depth, excess nitrate, which may be due to improper well construction and protection.

\section{SELECTED REFERENCES}

Adams, M. F., 1957, Water resources of the State of Washington: Washington State Coll. Inst. Technology Bull. 237, 20 p.

1960, Water resources of the State of Washington: Washircton State Coll. Inst. Technology Bull. 237, Supp. A, 9 p.

Crosby, J. W. III, and Chatters, R. M., 1965, Water-dating techniques as applied to the Pullman-Moscow ground-water basin: Washington State Univ. Research Div. Bull. 296, 21 p., 4 figs.

Foxworthy, B. L., 1962, Geology and ground-water resources of the Ahtanum Valley, Yakima County, Washington: U.S. Geol. Survey Water-Supply Paper 1598, 100 p., 11 figs.

Foxworthy, B. L., and Washburn, R. L., 1963, Ground water in the Pullman area, Whitman County, Washington: U.S. Geol. Survey Water-Supply Paper 1655, 71 p., 17 figs.

Hampton, E. R., and Brown, S. G., 1964, Geology and ground-water resources of the Upper Grande Ronde River basin, Union County, Oregon: U.S. Geol. Survey Water-Supply Paper 1597, 99 p., 22 figs.

Hart, D. H., and Newcomb, R. C., 1965, Geology and ground water of the Tualatin Valley, Oregon: U.S. Geol. Survey Water-Supply Paper 1697, 172 p., 3 pls., 17 figs.

Hem, J. D., 1959, Study and interpretation of the chemical characterist: $\mathrm{s}$ of natural water: U.S. Geol. Survey Water-Supply Paper 1473, $2 € 9$ p., 40 figs.

Hogenson, G. M., 1964, Geology and ground water of the Umatilla River basin, Oregon: U.S. Geol. Survey Water-Supply Paper 1620, 162 p., 2 pls., 14 figs.

Huntting, Marshall T., 1961, Geologic map of Washington: Olympia, Vashington Dept. Conserv.

Irwin, W. H., 1946, Engineering problems of the Grand Coulee area, Columbia Basin project, Washington [abs.] : Geol. Soc. Am. Bull., v. 57, nา. 12, pt. 2, p. 1207. 
Jones, F. O., 1950, Columbia River basalts, in A recorded symposium: Northwest Sci., v. 24, p. 55.

La Sala, A. M., Jr., and Doty, G. C., 1971, Preliminary evaluation of hydrologic factors related to radioactive waste storage in basaltic rocks at the Hanford Reservation, Washington: U.S. Geol. Survey open-file report, 68 p., 10 figs.

Mackin, J. H., 1961, A stratigraphic section in the Yakima Bas ${ }^{2}$ lt and the Ellensburg Formation in south-central Washington: Washington Div. Mines and Geology Rept. Inv. 19, 45 p., 13 figs.

Newcomb, R. C., 1959, Some preliminary notes on ground water in the Columbia River basalt: Northwest Sci., v. 33, no. 1, p. 1-18.

1961, Storage of ground water behind subsurface dams in the Columbia River Basalt, Washington, Oregon, and Idaho: U.S. Geol. Survey Prof. Paper 383-A, 15 p., 12 figs.

1965 , Geology and ground-water resources of the Walla walla River basin, Washington-Oregon: Washington Div. Water Resources WaterSupply Bull. 21, 151 p., 19 figs.

1969, Effect of tectonic structure on the occurrence of ground water in the basalt of the Columbia River Group of The Dalles area, Oregon and Washington: U.S. Geol. Survey Prof. Paper 383-C, 33 p., 19 figs. 1970, Tectonic structure of the basalt of the Columbia River Group, Washington, Oregon, and Idaho: U.S. Geol. Survey Misc. Gecl. Inv. Map I-587, scale $1: 500,000$.

Piper, A. M., 1932, Geology and ground-water resources of The Drlles region, Oregon: U.S. Geol. Survey Water-Supply Paper 659-B, 101 p., 12 figs.

Robison, J. H., 1971, Hydrology of basalt aquifers in the Hermiston-Ordnance area, Umatilla and Morrow Counties, Oregon: U.S. Geol. Sur"rey Hydrol. Inv. Atlas, HA-387.

Santos, J. F., 1965, Quality of surface waters in the lower Columbia basin: U.S. Geol. Survey Water-Supply Paper 1784, 78 p., 29 figs.

Silar, Jan, 1969, Ground water structures and ages in the easter ${ }^{n}$ Columbia Basin, Washington: Washington State Univ. Coll. Eng., Research Div. Bull. 315, 165 p., 16 figs.

Stevens, P. R., 1960, Ground-water problems in the vicinity of Moscow, Latah County, Idaho: U.S. Geol. Survey Water-Supply Paper 146)-H, 32 p., 1 pl., 8 figs.

U.S. Public Health Service, 1962, Drinking water standards, 1962 : U.S. Public Health Service Pub. 956, 61 p.

U.S. Salinity Laboratory Staff, 1954, Diagnosis and improvement of saline and alkali soils: U.S. Dept. Agriculture Handb. 60, 160 p.

Van Denburgh, A. S., and Santos, J. F., 1965, Ground water in Washington: Washington Div. Water Resources Water-Supply Bull. 24, 93 p., 12 figs.

Walters, K. L., and Grolier, M. J., 1960, Geology and ground-water resources of the Columbia Basin Project area, Washington: Washington Div. Water Resources Water-Supply Bull. 8, v. 1, 518 p., 3 pls., 25 figs.

Wells, Francis G., Peck, Dallas L., 1961, Geologic map of Oregon west of the 121st meridian: U.S. Geol. Survey Misc. Geol. Inv. Map I-325. 


\section{TABLES 1-3}




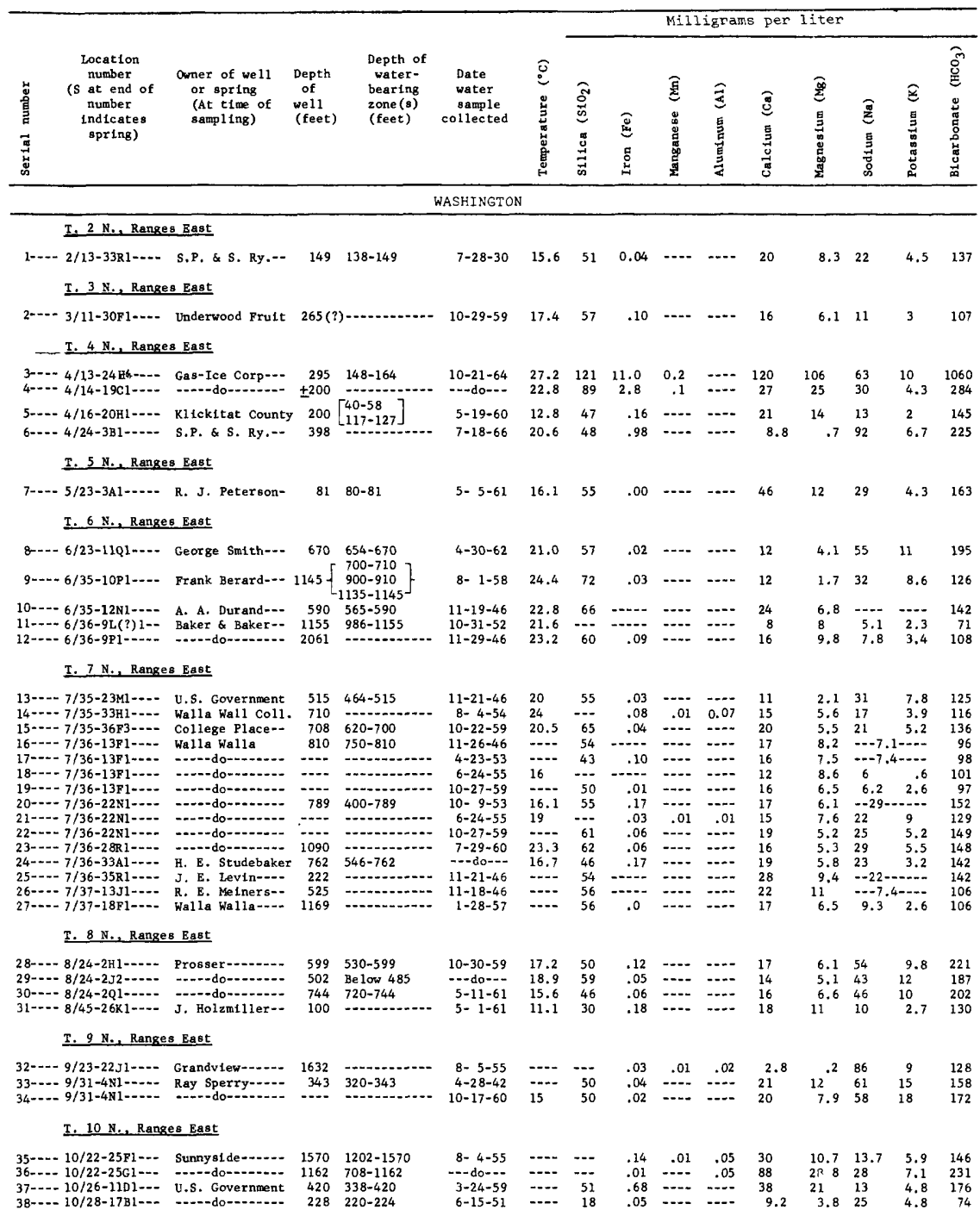

TABLE 1. - Chemical analyses of ground water in the basalt [Analyses by the U.S. Geological 


\begin{tabular}{|c|c|c|c|c|c|c|c|c|c|c|c|c|c|c|c|}
\hline \multirow{3}{*}{ 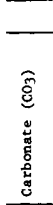 } & \multicolumn{10}{|c|}{ Milligrams per liter--Con. } & \multirow{3}{*}{ 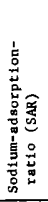 } & \multirow{3}{*}{ 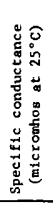 } & \multirow[b]{3}{*}{$\mathrm{pH}$} & \multirow[b]{3}{*}{$\frac{a}{0}$} & \multirow{3}{*}{ Remarks } \\
\hline & & & & & & & $\begin{array}{r}\mathrm{D} 1 \mathrm{~s} \\
80 \\
\end{array}$ & $\begin{array}{l}\text { solved } \\
\text { lids }\end{array}$ & Hard & ness & & & & & \\
\hline & 离 & 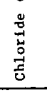 & 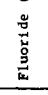 & 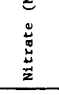 & 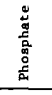 & 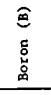 & 䢘 & 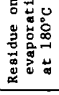 & $\begin{array}{l}\delta \\
8 \\
8 \\
8 \\
\end{array}$ & 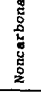 & & & & & \\
\hline \multicolumn{15}{|c|}{ WASHINGTON } & \\
\hline$\cdots$ & 18 & 4.0 & $\cdots$ & 0.00 & $\cdots$ & $\cdots$ & $\cdots$ & 195 & 84 & $\cdots$ & 1.0 & $\cdots$ & $\cdots$ & $\cdots$ & $\begin{array}{l}\text { WSP (Water Supply Paper) 659-B. } \\
\text { Klfckitat County. }\end{array}$ \\
\hline 0 & .7 & 4.8 & 0.2 & .0 & 0.09 & $-\cdots$ & 152 & 158 & 65 & $\cdots$ & .6 & 145 & 7.9 & 0 & Wash. WSB (Water Supply Bull.) $24 .^{2}$ \\
\hline $\begin{array}{l}0 \\
0\end{array}$ & $\begin{array}{r}3.4 \\
.0\end{array}$ & $\begin{array}{l}3.5 \\
3.2\end{array}$ & $\begin{array}{r}.4 \\
1.1\end{array}$ & .3 & .03 & $\begin{array}{r}0.11 \\
.03\end{array}$ & $\begin{array}{l}950 \\
320\end{array}$ & $\begin{array}{l}964 \\
325\end{array}$ & $\begin{array}{l}734 \\
172\end{array}$ & $\begin{array}{l}0 \\
0\end{array}$ & $\cdots$ & $\begin{array}{r}1410 \\
429\end{array}$ & $\begin{array}{l}6.6 \\
6.4\end{array}$ & $\begin{array}{l}0 \\
0\end{array}$ & $\begin{array}{l}\text { Well 10. Carbon dioxide source. } \\
\text { Well } 2 . \quad \text { Do. }\end{array}$ \\
\hline 0 & 3.8 & 6.2 & .3 & 8.0 & .10 & $\cdots$ & 286 & 181 & 110 & $\cdots$ & .5 & 271 & 7.5 & 5 & Wash. WSB 24 . \\
\hline 0 & .0 & 34 & 1.6 & .1 & $\cdots$ & -- & 303 & 306 & 25 & 0 & 8.0 & 460 & 8.0 & 0 & Whitc omb Sta, well. Benton County. \\
\hline 0 & 46 & 27 & .5 & 10 & .13 & $-\cdots$ & 310 & 333 & 165 & $\cdots$ & 1.0 & 464 & 7.9 & 0 & Wash. WSB 24 . Klickitat County. \\
\hline 0 & 2.2 & 9.8 & 1.0 & .6 & .10 & $\cdots$ & 249 & $\cdots$ & 47 & 0 & 3.5 & 344 & 8.1 & 0 & \\
\hline 0 & 3.2 & 6.5 & .7 & .0 & .00 & $\cdots$ & 199 & 186 & 37 & 0 & 2.3 & 226 & 8.2 & $\cdots$ & Wash. WSB 21 . Walla Walla County. \\
\hline 0 & $\begin{array}{r}31 \\
2\end{array}$ & $\begin{array}{r}6.5 \\
.7\end{array}$ & .6 & .2 & 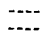 & $\cdots$ & 238 & 144 & $\begin{array}{l}88 \\
51\end{array}$ & $\begin{array}{c}0 \\
\cdots\end{array}$ & .8 & $\begin{array}{r}239 \\
-.-\end{array}$ & 8.0 & --- & Wash. Inst. Tech. $B-237$, no. $22^{3}$ \\
\hline-- & 5.7 & 3.8 & .6 & .4 & $\cdots$ & $\cdots$ & 161 & 144 & $\begin{array}{l}31 \\
88\end{array}$ & 0 & .0 & 186 & 3.0 & $\cdots$ & Wash. WSB 21 . \\
\hline$\cdots$ & 3.8 & 3.6 & .6 & .1 & $--\infty$ & & 177 & & & & & & & & $\begin{array}{l}\text { Wash. WSB } 21 \text {. Bonneville Pover } \\
\text { Admin. substation well. }\end{array}$ \\
\hline$\cdots$ & 3.8 & 1.6 & $\cdots$ & $\ldots$ & $\ldots$ & .14 & 235 & $\cdots$ & $\ldots$ & -.- & 1.0 & $\ldots$ & $\overline{7.6}$ & +- & Farm well. \\
\hline 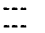 & 5.4 & 4.2 & .5 & .0 & $\cdots$ & $\cdots$ & 200 & $\cdots$ & 72 & 0 & 1.1 & 229 & 8.2 & $\cdots$ & Wash. WSB 21. We11 3. \\
\hline$\cdots$ & 9.7 & 1.8 & .2 & .2 & $\cdots$ & $\ldots$ & 145 & $\cdots$ & 76 & 0 & $\ldots$ & 150 & $\cdots$ & $\cdots$ & Wash. WSB 21 . Well 1 . \\
\hline$\cdots$ & 3.1 & 2.8 & .2 & .2 & $\cdots$ & $\cdots$ & 144 & --- & 69 & $\ldots$ & $\cdots$ & $\cdots-$ & 7.6 & $\cdots$ & Wash. WSB 21 . Ara 1, by Char ${ }^{1}$ ton Lab. \\
\hline ב- & 2.4 & 3.9 & $\ldots$ & $\cdots$ & $\cdots$ & $\cdots$ & $\cdots$ & 136 & 66 & $\cdots$ & $\cdots$ & $\cdots$ & 7.3 & $\cdots$ & WIT B-237, no. 140 . \\
\hline$\cdots$ & 1.7 & 1.0 & .2 & .5 & $\cdots$ & $\cdots$ & 140 & $\cdots$ & 67 & 0 & .3 & 163 & 7.7 & -- & Wash. WSB 21 . \\
\hline 1.2 & 6.6 & 5.6 & .7 & .04 & $\cdots$ & -..- & 208 & -- & 68 & $\cdots$ & $\cdots$ & $\cdots$ & -- & $\cdots$ & Wash. WSB 21. Well 4 . \\
\hline$\ddot{--}$ & 5.3 & 5.7 & $\cdots$ & --- & --- & --- & -- & 186 & 70 & $\cdots$ & $\cdots$ & --- & 7.9 &.-- & WIT B-237, no, 142 . \\
\hline-- & 5.3 & 2.5 & .9 & .2 & $\cdots$ & $\cdots$ & 196 & $\cdots$ & 69 & 0 & 1.3 & 257 & 8.1 & -- & Wash. WSB 21 . \\
\hline-- & 5.0 & 3.0 & 1.0 & .1 & --- & $\cdots$ & 200 & -- & 62 & 0 & 1.6 & 245 & 8.2 & $\cdots$ & Wash. WSB 21. WeIl 5. \\
\hline-- & 2.8 & 2.5 & .7 & .1 & -..- & $\cdots$ & 173 & $\cdots$ & 71 & 0 & 1.2 & 230 & 8.2 & --- & Wash. WSB 21 . \\
\hline$\cdots$ & 30 & 3.2 & .6 & 3.4 & $\cdots$ & $\ldots$ & 221 & $\cdots$ & 108 & 0 & $\ldots$ & 231 & --- & $\cdots$ & Do. \\
\hline$-\cdots$ & $\begin{array}{l}19 \\
2.5\end{array}$ & $\begin{array}{l}3.2 \\
1.0\end{array}$ & $\begin{array}{l}.6 \\
.2\end{array}$ & $\begin{array}{r}3.9 \\
.2\end{array}$ & $\ldots$ & $\cdots$ & $\begin{array}{l}175 \\
132\end{array}$ & 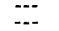 & $\begin{array}{r}100 \\
69\end{array}$ & 13 & .5 & $\begin{array}{l}227 \\
169\end{array}$ & $\ddot{8.0}$ & $-\cdots$ & Do. Wh. WSB 21 . Well 3. \\
\hline & & & & & & & & & & & & & & & \\
\hline 0 & .1 & 11 & .9 & .2 & .08 & $\cdots$ & 258 & 248 & 68 & $\cdots$ & 3.2 & 388 & 7.5 & 0 & Wash. WSB 24 , WeIl 3, Benton Co. \\
\hline 0 & 4.8 & 6.5 & .6 & .2 & .11 & $\cdots$ & 237 & 229 & 56 & $\cdots$ & 2.5 & 326 & 7.7 & 0 & Wash. WSB 24, We II 2 . \\
\hline 0 & .6 & 9.5 & .7 & .1 & .09 & $\cdots$ & 236 & 236 & 67 & $\cdots$ & 2.4 & 336 & 7.8 & 5 & Wash. WSB 24 . We I1 4. \\
\hline 0 & 5.2 & .8 & .3 & .3 & .13 & $\cdots$ & 143 & 136 & 89 & $\cdots$ & .5 & 210 & 8.1 & 5 & Wash. WSB 24. Asotin County. \\
\hline 40 & 5.3 & 19.1 & $\cdots$ & $\cdots$ & $--\cdot$ & .20 & $\cdots$ & 325 & 8 & $\cdots$ & 4.2 & & & & W1T B-237, no. 237 , \\
\hline 8 & 86 & 9.5 & .9 & .1 & $\cdots$ & $-\cdots$ & 341 & 336 & 102 & -.. & 2.6 & 480 & 30 & $\cdots$ & Wash. WSB 8, Franklin Count. \\
\hline 0 & 72 & 8.0 & 1.2 & .3 & .05 & $\cdots$ & 320 & 324 & 82 & $\cdots$ & 2.8 & 464 & 8.1 & 5 & Wash. WSB 24 . \\
\hline 3.6 & 19.2 & 7.1 & $\ldots$ & $\cdots$ & $\cdots$ & $\ldots$ & $\cdots$ & 303 & 119 & $\cdots$ & 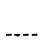 & 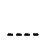 & 7.8 & $\cdots$ & $\begin{array}{l}\text { WIT B-237, no. 233, } \\
\text { WelI 4. Yakima County. }\end{array}$ \\
\hline 0 & 89 & 33 & $\cdots$ & $\cdots$ & --- & --- & $\cdots$ & 493 & 284 &.- & $\ldots$ & $\ldots$ & 7.6 & -- & WIT B-237, no. 230 , We11 1 , \\
\hline 0 & 43 & 7.5 & .2 & 4.5 & $\cdots$ & $\cdots$ & 270 & 262 & 182 & $\cdots$ & .4 & 397 & 7.7 & 5 & Wash. WSB 24. Benton County. \\
\hline 16 & 2.1 & 10 & 1.0 & .3 & ... & .06 & 119 & 130 & 39 & -.. & 1.8 & 206 & 9.2 & $\cdots$ & \\
\hline
\end{tabular}

of the Columbia River Group, Washington, Oregon, and Idaho Survey, unless noted otherwise] 


\begin{tabular}{|c|c|c|c|c|c|c|c|c|c|c|c|c|c|c|c|}
\hline \multirow[b]{2}{*}{ 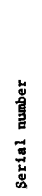 } & \multirow[b]{2}{*}{$\begin{array}{l}\text { Location } \\
\text { number } \\
\text { (s at end of } \\
\text { number } \\
\text { indicates } \\
\text { spring) }\end{array}$} & \multirow[b]{2}{*}{$\begin{array}{l}\text { Owner of vell } \\
\text { or spring } \\
\text { (At time of } \\
\text { sampling) }\end{array}$} & \multirow[b]{2}{*}{$\begin{array}{l}\text { Depth } \\
\text { of } \\
\text { weil } \\
\text { (feet) }\end{array}$} & \multirow[b]{2}{*}{$\begin{array}{l}\text { Depth of } \\
\text { water- } \\
\text { bearing } \\
\text { zone (s) } \\
\text { (feet) }\end{array}$} & \multirow[b]{2}{*}{$\begin{array}{c}\text { Date } \\
\text { vater } \\
\text { sample } \\
\text { collected }\end{array}$} & \multirow[b]{2}{*}{ 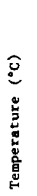 } & \multicolumn{9}{|c|}{ Milligrams per liter } \\
\hline & & & & & & & 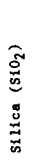 & $\begin{array}{l}\widehat{a} \\
\stackrel{g}{g} \\
\stackrel{5}{a}\end{array}$ & 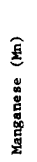 & 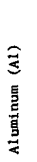 & 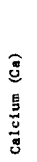 & 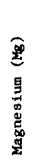 & 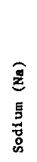 & 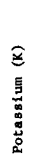 & 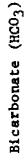 \\
\hline
\end{tabular}

WASHINGTON--CON.

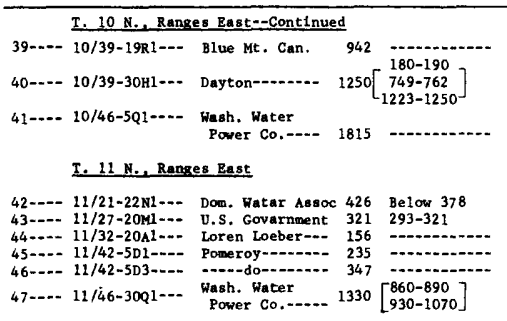

\section{T. 12 N., Ranges East}

48-..- 12/16-13D1--- Herke BroB.---- $146 \quad 130-140$ 49--.. 12/17-16D3--- Oral Brown-.-.- 384 325-384 50-... 12/17-16R1--- Borton \& Sons-- $1078 \quad 1035-1073$

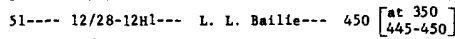

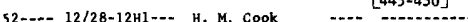

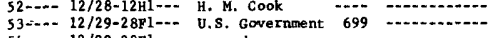

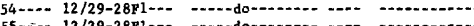
$55-2-12 / 29-28 \mathrm{r} 1-0$

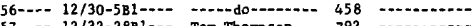

Tom Thomp 80 a

\section{T. 13 N., Rapges East}

$59-\ldots$ 13/24-25E1-... v.s. Goverament $777 \quad 652-777$ 60-... 13/24-26G1-.. ....--do-_..... 697 696-697 61--.- 13/24-36D1--. -..--do--.-.-. $1092 \quad 936-1092$

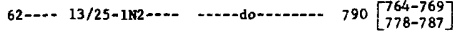
63-... 13/25-30G1-.. -...-do--...-..- 1110 860-1100

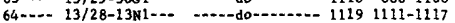

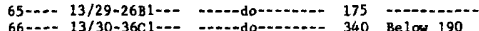

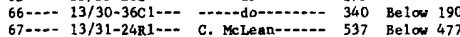
68-... 13/32-1J1-.. Conne11 Sand $220\left[\begin{array}{c}53-101 \\ 211-215\end{array}\right]$ 68-N-13/32-1J1- and Gravel Co- $220[211-215]$

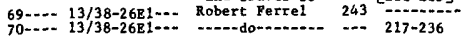

\section{T. 14 N. Ranges East}

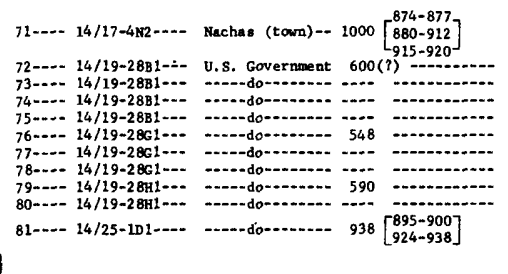

\begin{tabular}{|c|c|c|c|c|c|c|c|c|c|c|}
\hline $4-30-62$ & 16.1 & 43 & .04 & -.-- & $\ldots$ & 64 & 20 & 43 & 7.2 & 231 \\
\hline $6-15-51$ & $\cdots$ & 46 & .06 & .00 & $\ldots$ & 36 & 9.9 & 17 & & 162 \\
\hline $3-13-58$ & 15.0 & 37 & .25 & .02 & & 51 & 18 & 31 & 2.5 & 241 \\
\hline $6-23-55$ & $\cdots$ & -- & .02 & $\therefore$ & .01 & 29 & 14.2 & 9.9 & 4.3 & 171 \\
\hline $6-23-55$ & $\ldots$ & $\ldots$ & .004 & $\ldots$ & .01 & 27 & 12.7 & 10.6 & 3.1 & 151 \\
\hline $10-30-62$ & 23.3 & 66 & .01 & & .2 & 11 & 1.0 & 49 & 11 & 128 \\
\hline
\end{tabular}

\begin{tabular}{|c|c|c|c|c|c|c|c|c|c|c|}
\hline $8-30-51$ & $\cdots$ & 54 & t. 06 & .00 & -... & 16 & 9.7 & 10 & 1.8 & 116 \\
\hline $10-21-59$ & 15.5 & 53 & .05 & $\therefore$ & $\ldots$ & 13 & 5.3 & 17 & 3.2 & 113 \\
\hline $4-18-52$ & 17.2 & 38 & t.27 & .00 & $\cdots$ & 12 & 6.6 & 7.2 & 3.1 & 85 \\
\hline $4-27-42$ & $\ldots$ & 52 & .04 & $\cdots$ & - & 8.8 & 4.6 & 83 & 14 & 182 \\
\hline $10-17-60$ & 18.9 & 53 & t. 88 & $\ldots$ & $-\cdots$ & 7.5 & 1.9 & 84 & 16 & 192 \\
\hline $1-\quad-53$ & 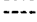 & $\ldots$ & ..... & $\ldots$ & & 9.4 & 4.6 & 46 & 6.3 & 116 \\
\hline $11-2-56$ & $\cdots$ & -- & .17 & $\cdots$ & & 9 & 4.5 & 45 & 6.6 & 108 \\
\hline $2-27-56$ & $\cdots$ & -- & $\cdots$ & $\cdots$ & & 13 & 3.9 & 48 & 9.4 & 104 \\
\hline $3-6-56$ & $\cdots$ & $\cdots$ & m.n. & $\cdots$ & & 31 & 21 & 15 & 3.9 & 156 \\
\hline $3-13-58$ & 19.5 & 70 & .03 & .0 & & 12 & 6.1 & 29 & 5.8 & 125 \\
\hline$-28-59$ & & 74 & .04 & & & 16 & 2.3 & 10 & 5.5 & 90 \\
\hline
\end{tabular}

$\begin{array}{lllllllllll}11-30-51 & 23.9 & 65 & .02 & .00 & \cdots & 19 & 12 & 27 & 8.5 & 189\end{array}$ $\begin{array}{lllllllllll}12-1-51 & 20.0 & 60 & .06 & .00 & \ldots . . & 20 & 12 & 27 & 6.7 & 193\end{array}$ $\begin{array}{lllllllllll}12-1-51 & 27.0 & 62 & .02 & .00 & \cdots-. & 17 & 9.4 & 30 & 9.9 & 181\end{array}$

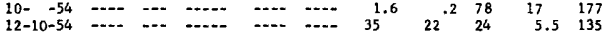

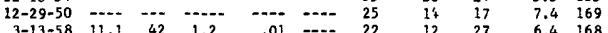
$\begin{array}{lllllllllll}10-17-60 & 13.9 & 37 & .06 & \ldots . . & \ldots . . & 32 & 19 & 27 & 4.6 & 184\end{array}$ $\begin{array}{rrrrrrrrrrr}10-17-60 & 13.9 & 37 & .06 & --.- & -.-2 & 32 & 13 & 27 & 4.6 & 184 \\ 8-2-54 & 20.0 & --. & .06 & .00 & .02 & 23 & 9.6 & 8.5 & 3.1 & 122\end{array}$ $\begin{array}{rrrrrrrrrrr}8-2-54 & 20.0 & --2 & .06 & .00 & .02 & 23 & 9.6 & 8.5 & 3.1 & 122 \\ 1-27-61 & 20.0 & 67 & .01 & . .-. & -.-- & 24 & 8.8 & 9.4 & 5.8 & 140\end{array}$
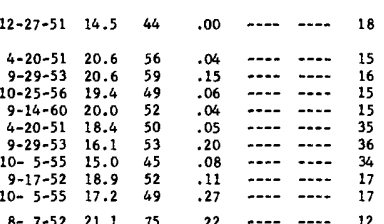

$\begin{array}{llll}6.7 & 7.5 & 3.3 & 96\end{array}$

$\begin{array}{llll}11 & 19 & 6.2 & 151 \\ 11 & 19 & 3.6 & 149\end{array}$ $\begin{array}{llll}11 & 19 & 3.6 & 149 \\ 11 & 19 & 3.5 & 149\end{array}$ 1. $32 \quad \begin{array}{lll}7.2 & 246\end{array}$ $\begin{array}{llll}12 & 32 & 4.5 & 239\end{array}$ i1) $22 \quad 4.5 \quad 154$ $\begin{array}{llll}9.3 & 20 & 4.6 & 151\end{array}$ $\begin{array}{llll}4.5 & 47 & 19 & 157\end{array}$

TABLE 1. - Chemical analyses of ground water in the basalt of the 


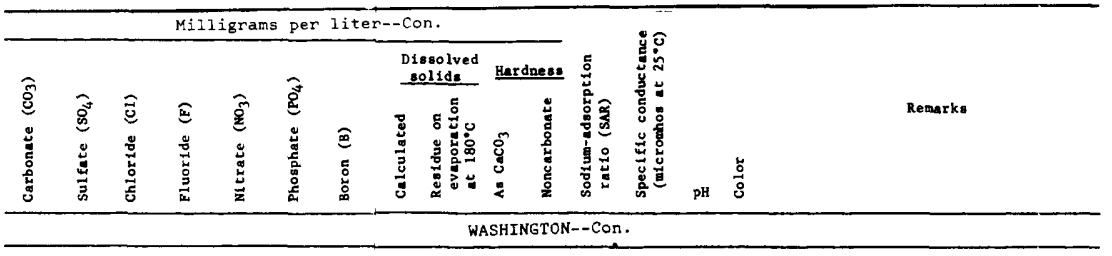

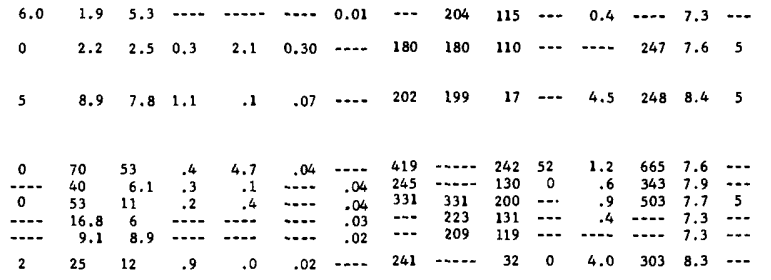

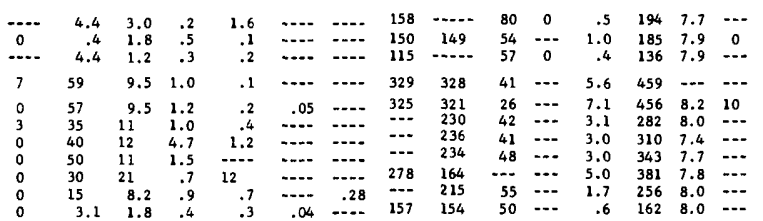
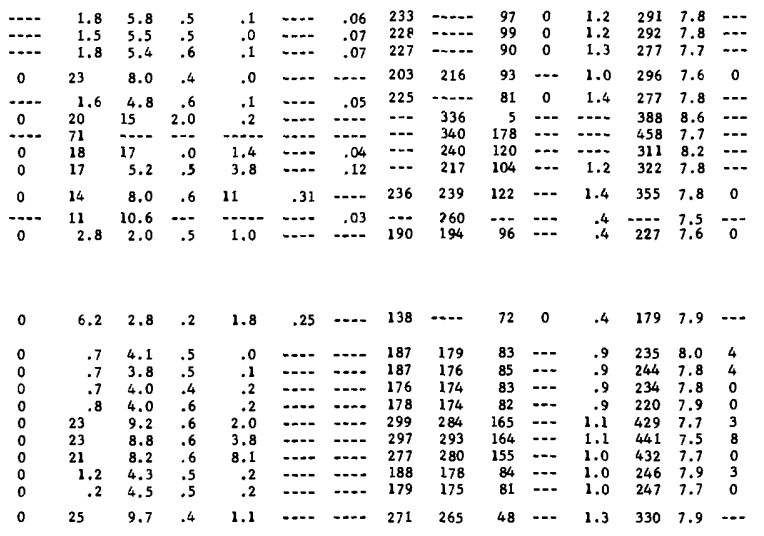

WIT B-237, no. 137.

Wash. WSB 24, Columbia County.

Wesh. WSB 24, Well 2. Asorin Co.

Yakima County.

WSP Benton County.

Wash. WSB 8. Prank1 in County.

WIT B-237, no. 136. Well 1. Garfield Co. WIT B-237, no. 135 . Well 3. Garfield Co.

Well 5. Asotin County.

WSP 1598. Yekima county.

Wash. WSB 24 .

WSP 1598.

Wesh. WSB 8.

Wesh. WSB 24. Franklin Courty.

Wash. WSB 8. Analyais by Bur. Recl. Do.

Do.

Wash. WSB 8.
Wash, WSB 24 . Well 4 , Gerfield Co.

Ford well. Benton County.

O'Brian well.

W8P

HeGee vell.

Anal. Bur. Recl. Wesh. WSB 8.Franklin Co, Do.

Wash. W8B 8 .

Wesh. WSB 24 .

TTT B-237, no. 271. Columbia Co.

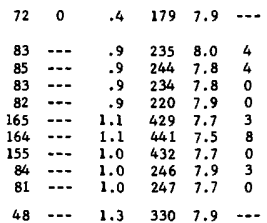

Yakima County.

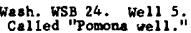

Do.

Do.

WSB 24. Called "Marie's well."

Do.

WSB 24 . Called "Southeast wcll."

Do.

Wesh wSB 24. Grent County.

Columbia River Group, Washington, Oregon, and Idaho - Continued 


\begin{tabular}{|c|c|c|c|c|c|c|c|c|c|c|c|c|c|c|c|}
\hline \multirow[b]{2}{*}{ 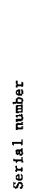 } & \multirow[b]{2}{*}{$\begin{array}{l}\text { Location } \\
\text { number } \\
\text { (s at end of } \\
\text { number } \\
\text { indicates } \\
\text { spring) }\end{array}$} & \multirow[b]{2}{*}{$\begin{array}{l}\text { Owner of wel1 } \\
\text { or spring } \\
\text { (At tine of } \\
\text { sampling) }\end{array}$} & \multirow[b]{2}{*}{$\begin{array}{l}\text { Depth } \\
\text { of } \\
\text { we11 } \\
\text { (feet) }\end{array}$} & \multirow[b]{2}{*}{$\begin{array}{c}\text { Depth of } \\
\text { water- } \\
\text { bearing } \\
\text { zone (s) } \\
\text { (feet) }\end{array}$} & \multirow[b]{2}{*}{$\begin{array}{c}\text { Date } \\
\text { water } \\
\text { sample } \\
\text { collected }\end{array}$} & \multirow[b]{2}{*}{ 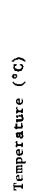 } & \multicolumn{9}{|c|}{ Milligrams per liter } \\
\hline & & & & & & & 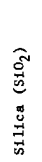 & $\begin{array}{l}\text { D } \\
\text { E } \\
5 \\
\text { E }\end{array}$ & 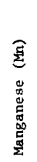 & 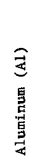 & 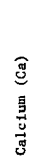 & 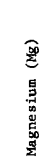 & 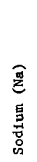 & 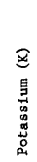 & 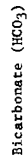 \\
\hline
\end{tabular}

\section{T. 14 N., Ranges East--Continued}

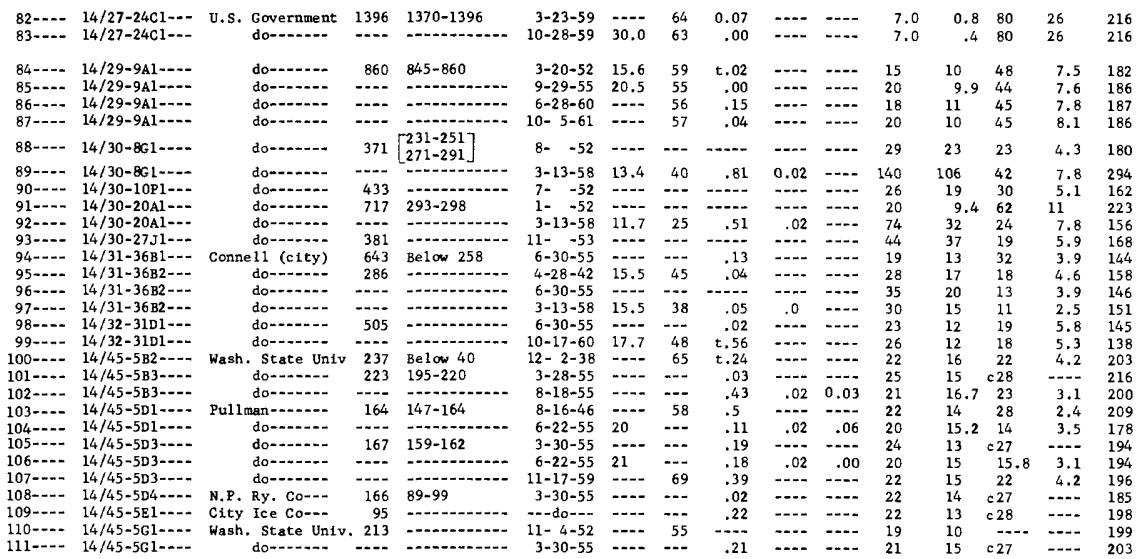

$110-\cdots 14 / 45-5 \mathrm{Gl} \cdots---$

\section{T. 15 N., Ranges East}

\begin{tabular}{|c|c|c|c|c|c|c|c|c|c|c|c|c|c|c|c|}
\hline $12---$ & $15 / 27-32 \mathrm{E} 1--$ & U.S. Government & 1140 & $982-1115$ & $10-28-54$ & 16.7 & 54 & .29 &.-- & $-\ldots$ & 21 & 8.8 & 26 & 12 & 146 \\
\hline $13 \cdots-$ & $15 / 27-34 \mathrm{~L} 2---$ & do-nente & 636 & $604-614$ & $1-7-58$ & 21.7 & -- & .07 & $\cdots$ & --- & 13 & 6.0 & 40 & 18 & 152 \\
\hline $14=--$. & $15 / 27-34 \mathrm{~L} 2=--$ & do--an-e- & $\cdots$ & (n)- & $3-24-59$ & $\cdots$ & 73 & .02 & -- & --- & 14 & 6.1 & 35 & 19 & 50 \\
\hline$\cdots$ & 5/28-8E1-... & C.M.St.P.\&Pac.Ry & 415 & $371-414$ & $10-18-60$ & 17.8 & 65 & $t .61$ & $-\cdots$ & --- & 30 & 14 & 34 & 10 & 96 \\
\hline $6-\cdots$ & $15 / 28-15 \mathrm{D} 1--$. & Saddle Mt. Water & 865 & -....- & $1-\quad-52$ & $\cdots$ & $-\infty$ & $\cdots$ & $-\cdots$ & $\cdots$ & 20 & 15 & 33 & 9.4 & 91 \\
\hline $7 \cdots$ & $15 / 28-15 \mathrm{D} 1-\cdots$ & do-............ & $-\ldots$ & $-\cdots-$ & $2-\quad-52$ & --- & --- &.-- & & --- & 19 & & 56 & 11 & 98 \\
\hline- & $15 / 2$ & S. Government & 398 & $284-287$ & $2-\quad-52$ & --- & -- & $\cdots$ & & $--\pi$ & 29 & 22 & 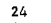 & 4.7 & 93 \\
\hline 9 & $15 / 2$ & $\cdots$ & --- & $-\ldots-\cdots$ & $12-\quad-53$ & --- & -. & $\cdots$ & & & 32 & 19 & 20 & & 73 \\
\hline & & 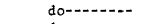 & $\ldots$ & 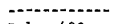 & $9-18-56$ & $\cdots$ & -- & - & $-\cdots$ & $\cdots$ & 1.8 & 0 & 222 & 1. & 176 \\
\hline $21-$ & $15 / 28-35 \mathrm{P} 1=-$ & do.- & 840 & $\begin{array}{l}\text { Below } 400 \\
250-252]\end{array}$ & $8-24-56$ & 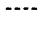 & $\cdots$ & $\cdots-$ & & & 24 & 15 & 25 & 5.9 & 169 \\
\hline & $15 / 2$ & oth & 693- & $\begin{array}{l}347-363 \\
570-574 \\
613-693\end{array}$ & 5 & & & .02 & & & 4.2 & 1.8 & 77 & 1,3 & 170 \\
\hline 3 & - & $\cdots$ & 560 & & 2 & 20.0 & 52 & .04 & $\ldots$ & $--\cdot$ & 3. & 3. & 78 & 12 & 183 \\
\hline 4 & $15 /$ & $\ldots$ & $\ldots$ & $\cdots$ & $8-2-55$ & $\cdots$ &.- & .02 & & $\cdots$ & 2 . & 1.2 & 69 & 13 & 62 \\
\hline & $\cdots$ & Othe 1 & 550 & $\cdots$ & 7- & -- & --- & $\cdots$ & & & 19 & 12 & 40 & 5. & 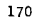 \\
\hline 6. & $15 /$ & G. Kleit & 415 & $\ldots$ & $3-11-58$ & --- & 38 & .40 & .0 & & 18 & 8.5 & 36 & 9 & 172 \\
\hline 7 & - & s. G & 492 & $-\cdots-$ & $3-1$ & --- & --- & .04 & $\ldots$ & $\cdots$ & & 16 & 25 & & 175 \\
\hline & & orge $\mathrm{Pe}$ & 353 & -- & $10-1$ & 15.0 & 66 & .0 & & & & 2.1 & 51 & & 160 \\
\hline 29 & -- & le-- & 144 & & $5-$ & $\cdots$ & 47 & .0 & & & 3 & & 1 & & 4 \\
\hline 0 & -- & Mil $1 \mathrm{am}-$ & 378 & 370 & $7-3$ & $\cdots$ & $\cdots$ & .0 & & & 34 & 19.8 & 22 & 5. & 250 \\
\hline & 15 & $\mathrm{Gre}$ & 226 & $\ldots$ & $\cdots$ & $\ldots$ & $\cdots$ & .0 & & .0 & 3 & 18 & 20 & 5. & \\
\hline & & - & 302 & & & -- & --- & .6 & & & & & c 2 & & \\
\hline & $15 /$ & allman & 231 & $170-176$ & $--\operatorname{do}$ & 13.9 & $\cdots$ & .3 & - & $\ldots$ & 2 & & c 22 & -- & 184 \\
\hline & $1--$ & do-s- & $\ldots$ & -nen- & $6-22-55$ & 20 & $\ldots$ & .02 & & & 20 & 15.7 & 17. & 3. & 184 \\
\hline 35 & $15 / 45-32 \mathrm{~N} 2--$ & do-. & 954 & Below 399 & 1959 & 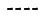 & 60 & .36 & & & 24 & 13 & 22 & 4.1 & 194 \\
\hline
\end{tabular}

TABLE 1. - Chemical analyses of ground water in the basalt of the 


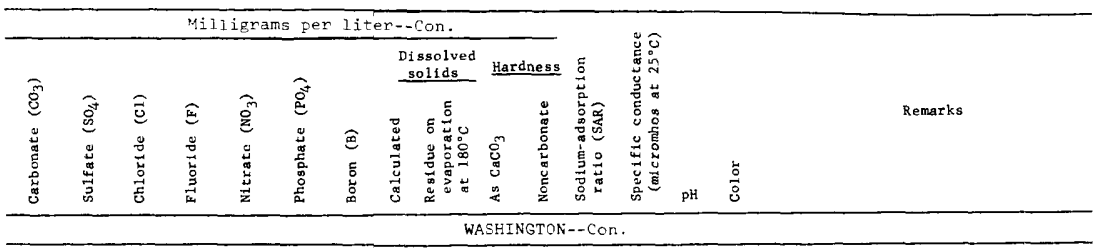

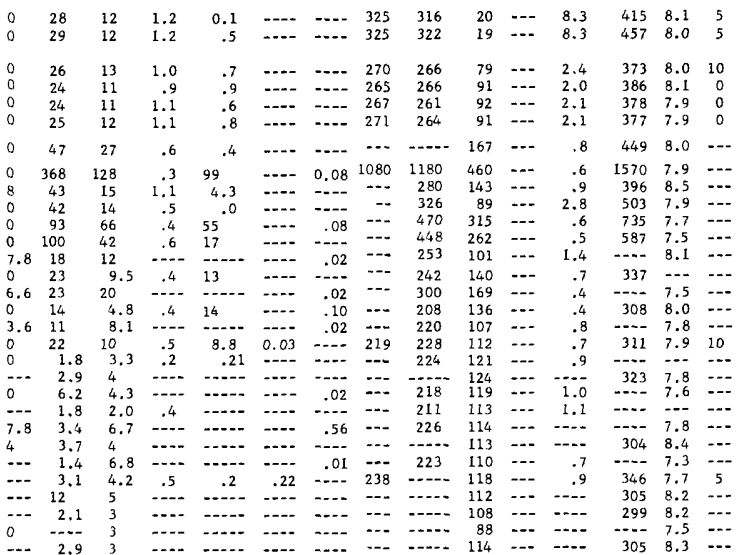

Wash. WSB 24.

Wash. WSB 24. Franklin Co.

Wash. WSB 8. Anal. Bur. Reclamation. Wash. WSB 8 .

Wash. WSB 8. Anal. Bur. Reclamation. Do.

Washertent artficial recharge. WIT B-237, no. 159 . We1 2 .

Wash. WSB 8 , Well 1.

WIT B-237, no. 158 .

Wash, WSB 8

WIT B 237, no, 160. Wel1 3 .

Wash. WSB 24.12 . Whitman Co.

USP 1655. Powerhouse well 2 .

WIT B-237, no. 245 .

WSP 1655. City weli 2. Idaho Health. WIT $B-237$, no. 127 .

WSP 1655 .

WIT B-237, no, 128 .

WSP 1655, Wei1 3 .

WSP 1655 .

Do.

Do.

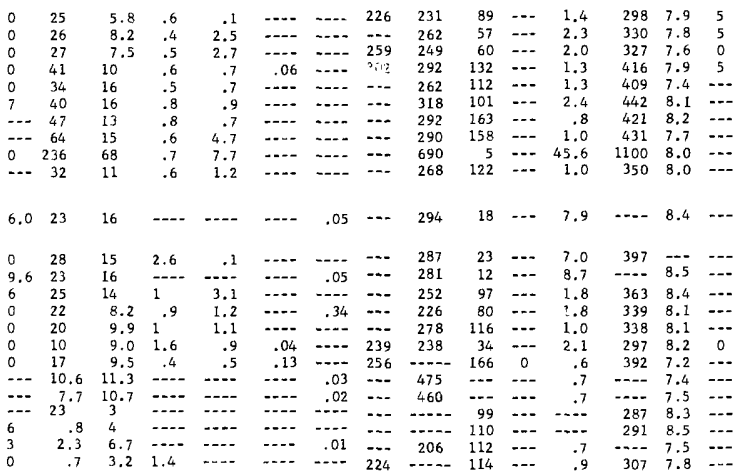

Wash. WSB 24, Grant Count". Do.

Wash. WSB 8. Anal. Bur. Reriamation. Do. "Upper Saddle Gap Well."

Do. Sampled after art.rech. Wash. WSB 8. Anal. Bur. Roclamation. WIT B-237, no, 215. City Park we11.

Wash. WSB 8 . City Hall well.

WIT B-237, no. 216 .

Wash. WSB 8, Anal, Bur. Rạclamation. Wash. WSB 8 .

Wash. WSB 8. Anal. Bur, Reclamation. Wash. WSB 21 .

WIT B-237, no, 269. Whitman County.

WIT $3-237$, no. 268 .

WSP 1655 .

WSP 1655. City well 2.

WIT B-237, no. 129. WSP 1655 . City we 11 4. Wash. WSB 24
lists temperature as $14.5^{\circ} \mathrm{C}$ in 1958 .

Columbia River Group, Washington, Oregon, and Idaho - Continued 


\begin{tabular}{|c|c|c|c|c|c|c|c|c|c|c|c|c|c|c|c|}
\hline \multirow[b]{2}{*}{ 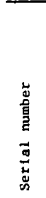 } & \multirow[b]{2}{*}{$\begin{array}{l}\text { Location } \\
\text { number } \\
\text { (s at end of } \\
\text { number } \\
\text { Indicates } \\
\text { spring) }\end{array}$} & \multirow[b]{2}{*}{$\begin{array}{l}\text { Ouner of vell } \\
\text { or spring } \\
\text { (At t1me of } \\
\text { sacpling) }\end{array}$} & \multirow[b]{2}{*}{$\begin{array}{l}\text { Depth } \\
\text { of } \\
\text { well } \\
\text { (feet) }\end{array}$} & \multirow[b]{2}{*}{$\begin{array}{l}\text { Depth of } \\
\text { water- } \\
\text { bearing } \\
\text { zone (s) } \\
\text { (feet) }\end{array}$} & \multirow[b]{2}{*}{$\begin{array}{c}\text { Date } \\
\text { water } \\
\text { sample } \\
\text { collected }\end{array}$} & \multirow[b]{2}{*}{ 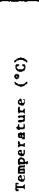 } & \multicolumn{9}{|c|}{ Milligrams per liter } \\
\hline & & & & & & & 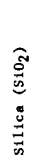 & $\begin{array}{l}\bar{Q} \\
\stackrel{2}{5} \\
\overline{5}\end{array}$ & 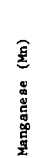 & 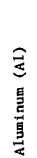 & 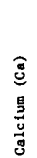 & 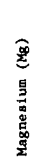 & 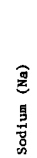 & 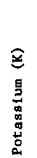 & 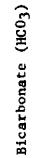 \\
\hline
\end{tabular}

WASHINGTON--CON.

\section{T. 16 N., Ranges East}

\begin{tabular}{|c|c|c|c|c|}
\hline 16-...- & $16 / 24$ & U.S. Government & 800 & {$\left[\begin{array}{l}709 \\
727-748\end{array}\right]$} \\
\hline 17-1 & $16 / 24-1 G 2---$ & -+- do $=$ & 915 & {$\left[\begin{array}{l}725-730 \\
884-887\end{array}\right]$} \\
\hline $38-\cdots$ & $16 / 24-1 G 2=-$ & -..-do- & - & \\
\hline & & 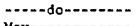 & 851 & Be low 700 \\
\hline & $\ldots$ & $\cdots$ & 304 & 170 \\
\hline & & & & 407 \\
\hline & $16 / 3$ & overnment & 392 & $345-392$ \\
\hline & $16 / 3$ & $\cdots$ do--and & $\cdots$ & $\cdots-\cdots$ \\
\hline & $16 / 3$ & -...-do-- & $\cdots$ & $\cdots$ \\
\hline & 16 & $\cdots$ & $\cdots$ & \\
\hline & & Colf & 600 & $515-545$ \\
\hline & & & & \\
\hline & & & -1 & \\
\hline & $16 / 4$ & do & & Below \\
\hline
\end{tabular}

\begin{tabular}{|c|c|c|c|c|c|c|c|c|c|c|}
\hline $1-24-60$ & 23.3 & 51 & 0.26 & $\cdots$ & $\cdots$ & 40 & 24 & 45 & 10 & 252 \\
\hline $11-17-59$ & 23.3 & 57 & .22 & -- & & 38 & 24 & 45 & 9.6 & 250 \\
\hline $12-12-59$ & 24.4 & 50 & .22 & - & & 40 & 24 & 45 & 10 & 254 \\
\hline 9 & $\cdots$ & $\cdots$ & $\cdots$ & & & 39 & 2 & & & \\
\hline $3-11-58$ & ... & 36 & .14 & 0.01 & & 5.6 & 3.2 & 86 & 26 & 212 \\
\hline $5-4-61$ & 22.8 & 62 & .00 & & & 3.0 & .8 & 81 & 12 & 170 \\
\hline 6- -55 & $\cdots$ & -- & $\cdots$ & & & 12 & & 67 & 11 & 197 \\
\hline $10-18-60$ & 15.6 & 53 & .04 & & & 15 & 19 & 32 & 1.7 & 144 \\
\hline $5-4-61$ & 16.1 & 53 & .00 & - & & 18 & 2 & 26 & 2.2 & 152 \\
\hline $4-12-57$ & $\cdots$ & $-\cdots$ & $\cdots$ & & & 17 & 17 & 44 & 3.9 & 171 \\
\hline $8-18-55$ & 23.5 & -.- & .10 & .0 & & 19 & 13.5 & 21 & 2.3 & 172 \\
\hline $6-20-58$ & 22 & $\cdots$ & .12 & . & & 25 & 9 & 22 & 2.3 & 185 \\
\hline . - do- & $\cdots$ & -- & .12 & ( & & 28 & 6 & 25 & 5.1 & 183 \\
\hline $11-\quad-59$ & 17.8 & 63 & .09 & . & . & 21 & 11 & 24 & 3.5 & 173 \\
\hline
\end{tabular}

\section{T. $17 \mathrm{~N}$., Ranges East}

\begin{tabular}{|c|c|c|c|c|c|c|c|c|c|c|c|c|c|c|c|}
\hline $0-\cdots$ & $17 / 25-11 \mathrm{E} 1-$ & v.s. Government & 285 & $233-285$ & $10-18-60$ & 16.7 & 51 & .02 & $\ldots$ & $\ldots$ & 30 & 25 & 25 & 2.6 & 216 \\
\hline $151=-$ & $17 / 25-23 \mathrm{~K} 1$. & 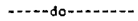 & 957 & $\ldots$ & $7-\quad-55$ & $\ldots$ & $\ldots$ & $\ldots$ & $\ldots$ & $\ldots$ & 36 & 16 & 74 & 8.2 & 203 \\
\hline $152=--$ & $17 / 25-23 \mathrm{KL}--$ & 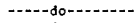 & --- & - & $2-\quad-56$ & --- & --- & .02 & $\cdots$ & $\cdots$ & 34 & 19 & 17 & 6.6 & 168 \\
\hline $153 \cdots$ & $17 / 25-23 \times 1--$ & 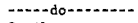 & $\cdots$ & $\ldots$ & $3-18-57$ & $-\cdots$ & -- & .05 & $\cdots$ & $-\cdots$ & 36 & 18 & 18 & 5.5 & 163 \\
\hline $154-$ & $17 / 26-2 B Q 1--$ & 0 . Abramson--..- & 404 & & $4-27-42$ & 14.5 & 42 & .44 & $\ldots$ & $\ldots$ & 32 & 18 & 43 & 13 & 182 \\
\hline $155-$ & $17 / 27-31 \mathrm{Dl}-$ & U.S, Government & 810 & $\lceil 46$ & 1951 & $\cdots$ & -- & $-\cdots$ & $\cdots$ & --- & 35 & 19 & 56 & 16 & 209 \\
\hline $156--$ & $17 / 28-12 \mathrm{D} 1--$ & - & 270 & & $4-25-51$ & $-\ldots$ & $-\cdots$ & -.... &.-- & $\cdots$ & 33 & 19 & 38 & 8.2 & 210 \\
\hline $157-$ & $17 / 30-10 \mathrm{~N} 1=$ & C.M.St.P.\&Pac.R & 499 & & 1944 & $\cdots$ & 55 & .1 & -... & & 17 & 9 & 31 & $\cdots$ & 165 \\
\hline $158-\cdots$ & $17 / 30-33 \mathrm{~K} 1-$. & U.S. Government & 1002 & & $10-28-59$ & 22.2 & 78 & .15 & $-\cdots$ & $\cdots$ & 8 & 2.1 & 57 & 10 & 162 \\
\hline $159--$ & $17 / 30-33 K 2-$ & - - - -do--ons & 981 & $635-98$ & $1-24-60$ & 23.3 & 79 & .45 & $-\ldots-$ & - & 8.5 & 1.9 & 57 & 9.9 & 161 \\
\hline $160-$ & $\cdots$ & - - do- & 155 & & $12-\quad-53$ & $\cdots$ & $\cdots$ & $\ldots$ & $\ldots$ & & 22 & 15 & 21 & 3.9 & 137 \\
\hline $161-$ & $17 / 31-8 R 1 \ldots$ & - & -- & $\cdots$ & $10-19-60$ & 13.9 & 39 & .01 & $\cdots$ & $\cdots$ & 12 & 15 & 11 & 1.0 & 121 \\
\hline $162-$ & $17 / 31-8 R 1--$ & - do-dons &..- & $\ldots$ & $5-3-61$ & 13.9 & 41 & .01 & -... & & 16 & 17 & 13 & 1.3 & 148 \\
\hline $163-$ & $17 / 31-3001--$ & c. w. Haugen--- & 337 & $\ldots$ & $3-12-58$ & 12.4 & 34 & .11 & .02 & 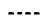 & 18 & 8 & 46 & 17 & 142 \\
\hline $164=$ & $17 / 32-6 \mathrm{~B} 1-$ & John Kulm--.... & 424 & $\cdots$ & -.-do-.. & 13.9 & 33 & .08 & .01 & & 16 & 12 & 41 & 12 & 168 \\
\hline 165 & $17 / 33-12 P 1=-$ & Clty of Lind--. & 286 & & $6-30-55$ & 16 & $\cdots$ & .47 & .01 & .02 & 30. & & 26.9 & 5.9 & 173 \\
\hline $166-$ & $17 / 33-13 D 1--$ & - do-ros & 382 & - & - do do- & 16 & -- & .05 & .01 & .01 & 22 & 11.4 & 20 & 3.5 & 136 \\
\hline $167-$ & $17 / 34-7 \mathrm{~N} 1-$ & 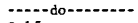 & 405 & $\cdots$ & ---do--- & 16 & $\cdots$ & .07 & & .03 & 78 & 57 & 74.2 & 7.0 & 204 \\
\hline $168-$ & $17 / 44-32 \mathrm{~A} 1=$ & Colffax- - & $\cdots$ & $\cdots$ & $6-20-58$ & 21 & $\cdots$ & .4 & .02 & .02 & 36 & 2.4 & 19 & 2.3 & 180 \\
\hline \multicolumn{16}{|c|}{ T. $18 \mathrm{~N}$, Ranges East } \\
\hline $69-$ & $18 / 23-36 \mathrm{HL}-$ & D. Davison-.... & 670 & $526-529$ & $5-8-50$ & $\ldots$ & $\ldots$ & --.-. &.- & & 32 & 22 & 30 & 6.6 & 220 \\
\hline & $11--$ & - & $\ldots$ & $665-668$ & $10-18-60$ & 15.6 & 55 & .01 & $\cdots$ & & 42 & 25 & 14 & 2.4 & 170 \\
\hline $171-$ & - 18/28-34R1- & U.S. Government & 268 & ............. & $7-29-47$ & $\cdots$ & $\cdots$ & $\ldots$ & -- & & 48 & 24 & $-\cdots-41$ & $1-\cdots$ & 297 \\
\hline 172 & -36D1-- & - do & 218 & & $2-\quad-52$ &..- & $\ldots$ & $\ldots$ & $\ldots$ & & 38 & 24 & 23 & 4.7 & 206 \\
\hline 173. & $-18 / 28-36 \mathrm{D} 1-$ & do-ndond & $\ldots$ & $\cdots$ & $5-10-56$ &.-- & $\ldots$ & $\ldots$ & $\ldots$ & $\cdots$ & 38 & 24 & 24 & 3.9 & 181 \\
\hline $174-$ & $-18 / 28-36 \mathrm{D} 1--$ & - - -do-no-n & --- & & $5-20-57$ & --- & -- & $\cdots$ & $\cdots$ & & 41 & 27 & 25 & 4.3 & 181 \\
\hline $175-$ & $-17 P 1--$ & 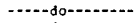 & 342 & $\cdots$ & $2-\quad-52$ & $\cdots$ & $\cdots$ & $\cdots$ & $\cdots$ & $\cdots$ & 18 & 14 & 36 & 11 & 171 \\
\hline 176- & $-18 / 29-17 P 1-\%$ & 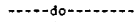 & -- & $\cdots+\cdots$ & $10-19-60$ & 15.0 & 58 & t. 29 & 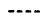 & & 53 & 34 & 28 & 3.5 & 180 \\
\hline & - 18/29-17PL-- & -ando-nos & $\ldots$ & n.m. & $5-3-61$ & 15.6 & 59 & $t .05$ & $\ldots$ & $\cdots$ & 63 & 36 & 29 & 3.6 & 160 \\
\hline 178 & $-18 / 30-16 \mathrm{R} 1=$ & 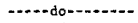 & 185 & $\cdots$ & $11-\quad-53$ & $\cdots$ & -- & $\cdots$ & -- & - & 22 & 16 & 33 & 2.7 & 179 \\
\hline 179 & $-18 / 31-23 A 1--$ & W. E. Franz $=$ & 355 & $310-355$ & $3-12-58$ & $\cdots$ & 30 & .11 & .0 & & 13 & 7.2 & 55 & 5.0 & 177 \\
\hline & $-18 / 39-12 \mathrm{~K} 1--$ & G. D Ferris--. & 115 & 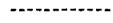 & $7-29-54$ & $\cdots$ & $\cdots$ & .05 & .00 & .02 & 29 & 13 & 9.9 & 3.1 & 172 \\
\hline \multicolumn{16}{|c|}{ T. $19 \mathrm{~N} .$, Ranges East } \\
\hline 181 & $-19 / 23-12 \mathrm{~A} 1=-$ & U.S. Government & 153 & $110-153$ & $11--53$ & $\ldots$ & $\ldots$ & $\ldots$ & $\cdots$ & 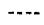 & 27 & 23 & 6.4 & 3.5 & 164 \\
\hline 182 & $-19 / 24-7 J 1-\ldots$ & Howard Hyer-.. & 502 & Below & $8-31-16$ & $\cdots$ & 42 & $\ldots$ & $\ldots$ & & 34 & 22 & \multicolumn{2}{|c|}{$\ldots-24-\ldots$} & 235 \\
\hline & $-19 / 24-7 \mathrm{~J} 1$ & $\ldots$ & $\cdots$ & ...... & $5-1-50$ &.-- & 44 & .07 & .0 & -8 & 27 & 18 & 32 & 5.9 & 221 \\
\hline & $19 / 24-75$ & -do- & & & $10-18-60$ & 15.6 & 48 & .46 & & & 31 & 25 & 11 & 2.7 & 176 \\
\hline & - 19/24-7J1--- & do-n.-. & & & $5-4-61$ & 12.8 & $\cdots$ & $\cdots$ & 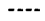 & & $\cdots$ & $\cdots$ & $-\cdots$ & $\cdots$ & 175 \\
\hline
\end{tabular}

TABLE 1. - Chemical analyses of ground water in the basalt of the 


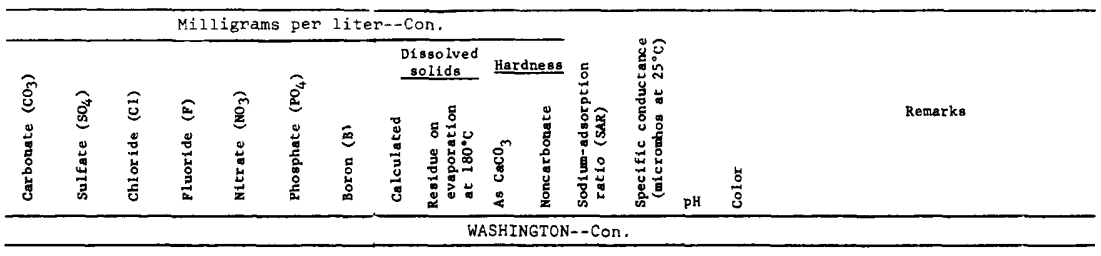

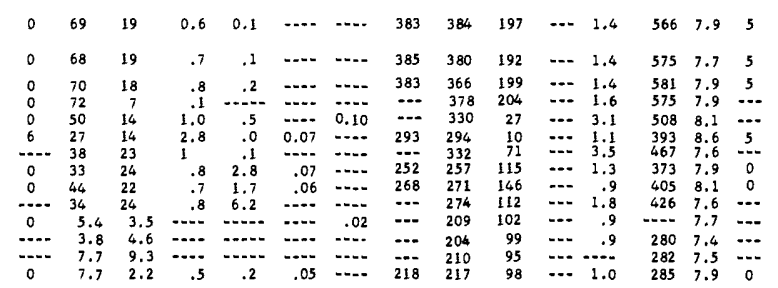

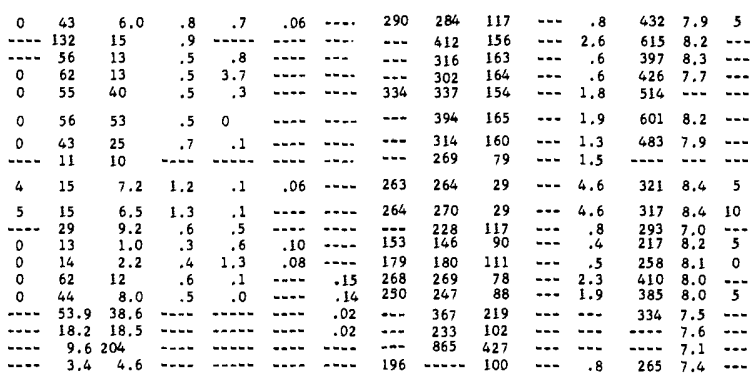
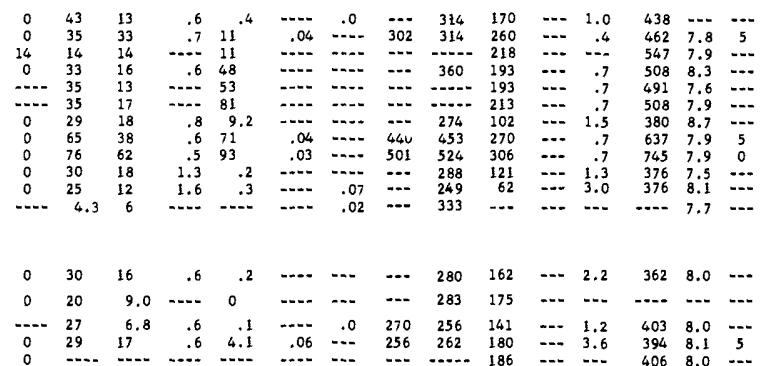

Wash, WSB 24. Grant County.

Do.

Do. Wash. WSB 8. Adams County.

Wash. WSB 24. City well 3 .

Wash. WSB 8. Anal. Bur. Rectamation. Wash. WSB 24 .

Wash. WSB 8. Anel. Bur. Reclamation. Wash. WSB 8. Anel. Bur. Reclamat ton.
WIT B-237, no. 243.Clay St.well, Wh1tmen Co. WIT B-237A, no. 303 .

WIT B-237A, no. 304. Falrview St, well. Wash WSB 24 118ts it as $14 \mathrm{~L}$.

Waah. WSB 24. Grant County.

Wash. WSB 8. Aral. Bur, Reclamation. Do.
Do.
Do.

Wash. WSB 8. Anatysis by owner Wash. WSB 24 .

$$
\text { Do. }
$$

Wash WSB 8.Anat.Bur.Recl.Adams Co, Wash. WSB 24 .

Wash. WSB 8 .

WIT B-237, no. 162, C1ty well 1 .

WIT B-237, no. 161. C1ty well 3 .

WTT B-237, no. 163. C1ty well 4 .

WIT B-237A, no. 302. Bast Glenwood well. Whitman Co.

Wash. WSB 8. Anal. Bur. Reclamation. Grant Coumty.

Wash. WSB 24 . Do. Do. Do.

Wash. WSB 24.

Do. Shows effects art. recharge.

Wash. WSB 8.Anal . Bur. Reclamation.

WIT B-237, no. 266. Whitman Co.

Wash. WSB 8 . Anslysis by Bureau Reclamation. Grant County. Well not cased to basalt.

Wash, WSB 8 . 


\begin{tabular}{|c|c|c|c|c|c|c|c|c|c|c|c|c|c|c|c|}
\hline \multirow[b]{2}{*}{ 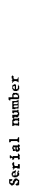 } & \multirow[b]{2}{*}{$\begin{array}{l}\text { Location } \\
\text { number } \\
\text { (s at end of } \\
\text { number } \\
\text { indicates } \\
\text { spring) }\end{array}$} & \multirow[b]{2}{*}{$\begin{array}{l}\text { OWner of we } 11 \\
\text { or spring } \\
\text { (at time of } \\
\text { sampling) }\end{array}$} & \multirow[b]{2}{*}{$\begin{array}{l}\text { Depth } \\
\text { of } \\
\text { we I1 } \\
\text { (feet) }\end{array}$} & \multirow[b]{2}{*}{$\begin{array}{l}\text { Depth of } \\
\text { water- } \\
\text { bearing } \\
\text { zone }(s) \\
\text { (feet) }\end{array}$} & \multirow[b]{2}{*}{$\begin{array}{c}\text { Date } \\
\text { water } \\
\text { sauple } \\
\text { collected }\end{array}$} & \multirow[b]{2}{*}{ 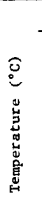 } & \multicolumn{9}{|c|}{ Milligrams per liter } \\
\hline & & & & & & & 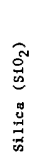 & $\begin{array}{l}\text { 产 } \\
\text { 总 }\end{array}$ & 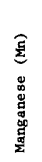 & 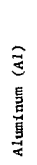 & 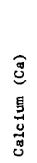 & 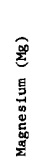 & 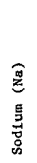 & 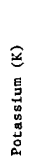 & 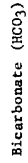 \\
\hline
\end{tabular}

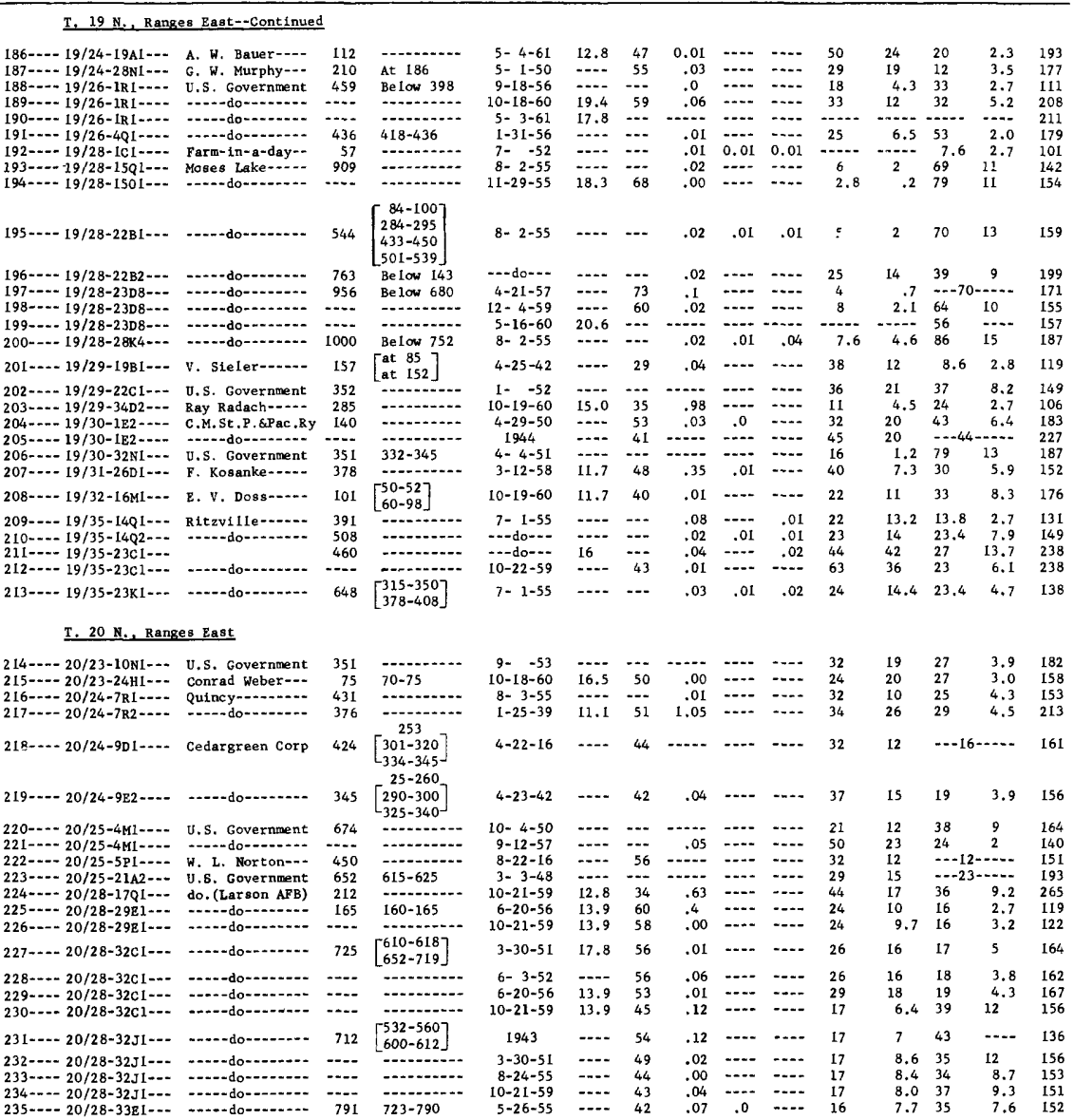

TABLE 1. - Chemical analyses of ground water in the brsalt of the 


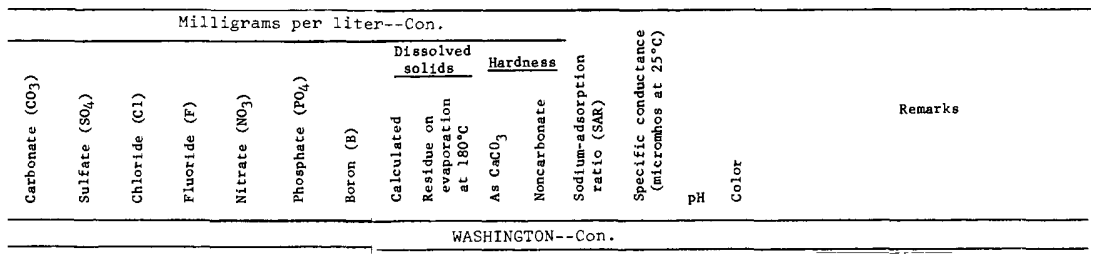

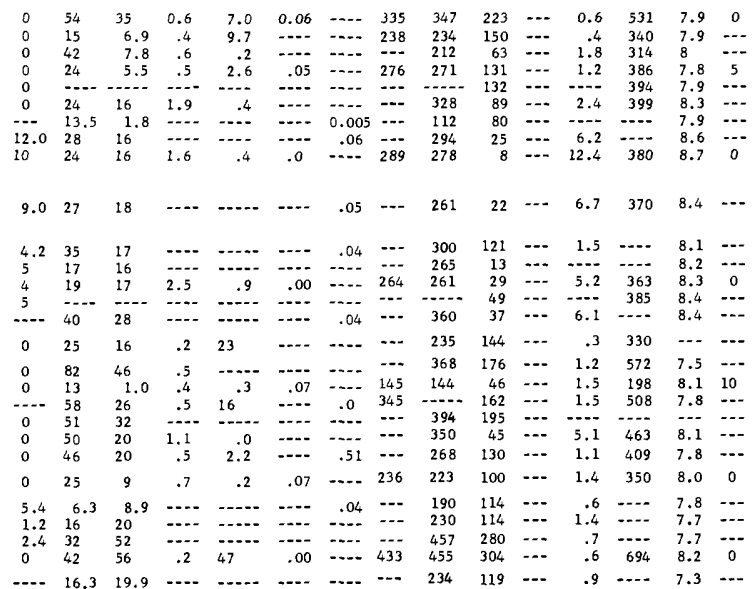

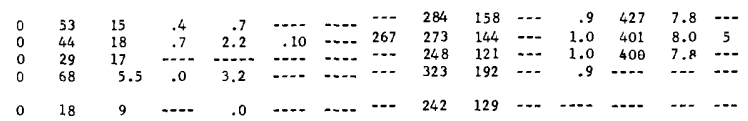

$\begin{array}{llllllllllllllllll}0 & 37 & 17 & .4 & 8.4 & \ldots & \ldots & \ldots & -.- & 272 & 154 & \ldots & .7 & 384 & \ldots & \ldots & \ldots\end{array}$

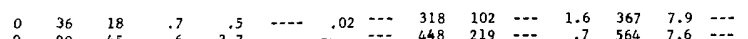

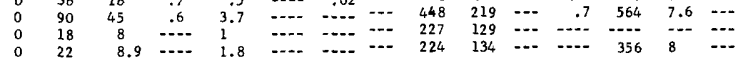

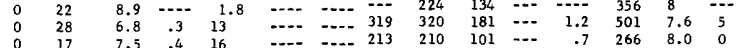

$\begin{array}{lllllllllllllll}0 & 17 & 7.5 & .4 & 16 & \ldots .-- & -. .- & 213 & 210 & 101 & \ldots-. & .7 & 266 & 8.0 & 0 \\ 0 & 17 & 7.2 & .3 & 13 & \ldots-.- & -.-- & 208 & 210 & 100 & \ldots & .7 & 276 & 7.5 & 5\end{array}$

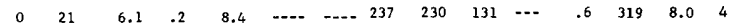

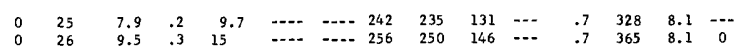

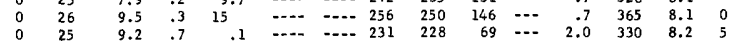

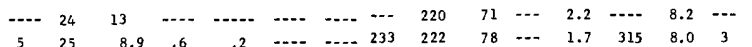

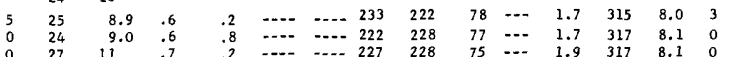

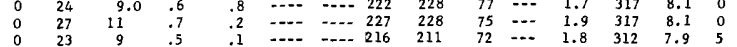

\section{Wash. WSB 24 .}

Wash, WSB 8 .

Wash. WSB 8. Ansl. Bur. Reclamation. Wash. WSB 24

Wesh. WSB 8. Anal. Bur. Reclamation. WIT B-237, no. 56 .

WIT B-237, no. 213 . Wel1 3 .

Wash. WSB 24 .

WIT B-237, no. 211 . We11 1 .

WIT B-237, no. 212 . Well 2 .

Wash, WSB 8. Well 7.Anal.comarer, 1 ab. Wash. WSB 24.

WIT B-237, no. 214. C1ty well 4 .

Wash. WSB 8 .

Wash. WSB 8. Anal. Bur. Reclamation. Wash. WSB 24

Wash. WSB 8. Ruff well. Anal. by owner. Wash. WSB 8. Anal. Bur. Reclamation. Wash. WSB 8. Adams County.

Wash. WSB 24.

WIT B-237, no. 166. C1ty well 1.

WIT B-237, no. 165. C1ty well 2 .

WIT B-237, no. 167. Owner's well 3 .

Wash. WSB 24 .

WIT B-237, no. 164 . Owner's well 4 .

Wash. WSB 8. Anal.Bur, Recl.Crant Co. Wesh.WSB 24 . Area artif.recharge.
WIT B-237, no, 218.C1ty wel1 1. Art.rech. Wash. WSB 8 . Unused well.

$$
\begin{aligned}
& \text { Do. } \\
& \text { Do. }
\end{aligned}
$$

Wash. WSB 8, Anal. Bur. Reclamation. Do. In area artificial recharge. Wash. WSB 8 .

Wash. WSB 8. Anal,Bur-Reclaration. Wash. WSB 24. Well ?.

Do. Two intervening anal. similar. Wash. WSB 24.Well 2. Five Intervening analyses are similar.

$$
\text { Do. }
$$$$
\text { Do. }
$$

Wash.WSB 8. Well 1, Anal, Leucks Lab. Wash. WSB 24 .

$$
\text { Do. }
$$

Do. Five intervening anal. similar. Wash. WSB 8. Well 3 .

Columbia River Group, Washington, Oregon, and Idaho - Continued 


\begin{tabular}{|c|c|c|c|c|c|c|c|c|c|c|c|c|c|c|c|}
\hline \multirow[b]{2}{*}{ 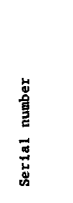 } & \multirow[b]{2}{*}{$\begin{array}{l}\text { Location } \\
\text { number } \\
\text { (s at end of } \\
\text { number } \\
\text { 1ndicates } \\
\text { spring) }\end{array}$} & \multirow[b]{2}{*}{$\begin{array}{l}\text { Owner of well } \\
\text { or spring } \\
\text { (at time of } \\
\text { sampling) }\end{array}$} & \multirow[b]{2}{*}{$\begin{array}{l}\text { Depth } \\
\text { of } \\
\text { well } \\
\text { (feet) }\end{array}$} & \multirow[b]{2}{*}{$\begin{array}{l}\text { Depth of } \\
\text { water- } \\
\text { bearing } \\
\text { zone(s) } \\
\text { (feet) }\end{array}$} & \multirow[b]{2}{*}{$\begin{array}{l}\text { Date } \\
\text { water } \\
\text { sample } \\
\text { collected }\end{array}$} & \multirow[b]{2}{*}{ 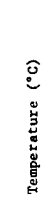 } & \multicolumn{8}{|c|}{ Milligrams per liter } & \multirow[b]{2}{*}{ 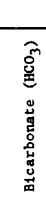 } \\
\hline & & & & & & & 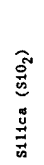 & 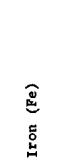 & 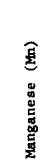 & 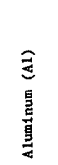 & 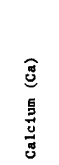 & 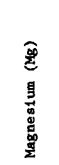 & 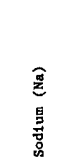 & 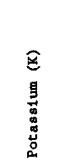 & \\
\hline \multicolumn{16}{|c|}{ WASHINGTON--CON. } \\
\hline \multicolumn{16}{|c|}{ T. $20 \mathrm{~N}$, Ranges East--Cont 1mued } \\
\hline $\begin{array}{l}236 \cdots \cdots \\
237 \cdots- \\
238-\cdots \\
239 \cdots \cdots \\
240 \cdots- \\
241 \cdots- \\
242 \cdots\end{array}$ & $\begin{array}{l}20 / 28-33 \mathrm{E} 1-- \\
20 / 28-33 \mathrm{E} 1 \cdots \\
20 / 29-11 \mathrm{Al}-\cdots \\
20 / 29-28 \mathrm{Cl}-- \\
20 / 31-22 \mathrm{NL}- \\
20 / 31-31 \mathrm{Bl}- \\
20 / 31-31 \mathrm{Bl}--\end{array}$ & $\begin{array}{l}\text { U.S. Government } \\
\text { do. (Larson AFB) } \\
\text { I. E. Cole--... } \\
\text { U.S. Government } \\
\text { Alvina Hansm-.. } \\
\text { J. BL achofff-... } \\
\end{array}$ & $\begin{array}{r}-\cdots \\
165 \\
416 \\
500 \\
400 \\
-\cdots\end{array}$ & 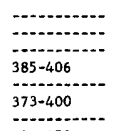 & $\begin{array}{c}11-5-57 \\
10-21-59 \\
4-30-50 \\
1951 \\
3-12-58 \\
10-19-60 \\
5-3-61\end{array}$ & $\begin{array}{l}15.6 \\
15.6 \\
\cdots \ldots . . \\
1 \ldots . \\
15.5 \\
13.3\end{array}$ & $\begin{array}{r}--. \\
42 \\
44 \\
-- \\
31 \\
42 \\
46\end{array}$ & $\begin{array}{c}0.12 \\
.02 \\
.1 \\
2.4 \\
.05 \\
.00\end{array}$ & $\begin{array}{c}0 . . \\
\cdots .0 \\
.01 \\
.01 \\
\cdots \\
\cdots\end{array}$ & $\begin{array}{l}\cdots \\
\cdots \\
\cdots \\
\cdots \\
\cdots \\
\cdots \\
\cdots\end{array}$ & $\begin{array}{l}18 \\
17 \\
31 \\
13 \\
18 \\
50 \\
38\end{array}$ & $\begin{array}{l}6.8 \\
6.9 \\
12 \\
6.7 \\
12 \\
27 \\
11\end{array}$ & $\begin{array}{l}35 \\
38 \\
21 \\
59 \\
51 \\
34 \\
37\end{array}$ & $\begin{array}{l}8.8 \\
9.3 \\
4.5 \\
13 \\
14 \\
9.6 \\
10\end{array}$ & $\begin{array}{l}151 \\
152 \\
145 \\
167 \\
208 \\
146 \\
151\end{array}$ \\
\hline 243 & $20 / 32-$ & U.S. Government & 502 & {$\left[\begin{array}{l}242-253 \\
334-355 \\
468-480\end{array}\right]$} & $12-1-59$ & 17.8 & 55 & .57 & $\cdots$ & $-\cdots$ & 15 & 5.8 & 36 & 6.4 & 156 \\
\hline $244 \cdots \cdots$ & 20/43-10RL-.- & Roselia-:--...- & 308 & (2) & $5-1-62$ & 11.1 & 46 & .05 & $\cdots$ & $\cdots$ & 34 & 13 & 25 & 2.2 & 196 \\
\hline \multicolumn{16}{|c|}{ T. $21 \mathrm{~N}$, Ranges East } \\
\hline $245=\ldots$ & $21 / 24-3111=$ & I. Overen-...... & 407 & (n)................ & $10-18-60$ & 15.6 & 50 & .08 & $\cdots$ & $\cdots$ & 36 & 8.7 & 17 & 3.5 & 140 \\
\hline $246-\cdots-$ & $21 / 26-8 M 1 \cdots$ & Ephrata--...-. & 1000 & {$\left[\begin{array}{l}391-430 \\
\text { Below } 430\end{array}\right]$} & $7-22-55$ & $\cdots$ & --- & .01 & $-\cdots$ & $-\cdot-$ & 16 & 13 & 22 & 3 & 146 \\
\hline $\begin{array}{l}247 \cdots-. \\
248-\cdots \\
249 \cdots \cdots\end{array}$ & $\begin{array}{l}21 / 26-8 \mathrm{~N} 1-\cdots \\
21 / 26-14 \mathrm{~L} 1-\cdots \\
21 / 26-15 \mathrm{~B} 1-\cdots\end{array}$ & Grant Co. PUD- & $\begin{array}{r}450 \\
1025 \\
347\end{array}$ & $756-1025$ & $\begin{array}{r}-\cdots \text { do }-. . \\
-- \text { do } \\
4-29-56\end{array}$ & 14.5 & --- & $\begin{array}{l}.01 \\
.004 \\
.04\end{array}$ & .01 & $\begin{array}{r}.00 \\
.01 \\
.0 .\end{array}$ & $\begin{array}{l}19 \\
14.4 \\
30\end{array}$ & $\begin{array}{l}12 \\
12.7 \\
15\end{array}$ & $\begin{array}{l}12 \\
12.7 \\
15\end{array}$ & $\begin{array}{l}2 \\
1.8 \\
5.3\end{array}$ & $\begin{array}{l}133 \\
150 \\
182\end{array}$ \\
\hline 250 & $21 / 26-16 \mathrm{~B} 3 \cdots$ & Ephrata-... & 260 & {$\left[\begin{array}{l}203-208 \\
241-242 \\
248-249\end{array}\right]$} & $4-25-42$ & 17.2 & 56 & .04 & $\cdots$ & $\cdots$ & 24 & 12 & 15 & 3.9 & 150 \\
\hline $251----$ & 21/26-16B3--- & - & .... & - & $7-22-55$ & $\ldots$ & --- & .02 &..- & .02 & 17 & $1+4$ & 14 & 5 & 147 \\
\hline $252-\ldots$ & $21 / 26-16 \mathrm{~B} 3 \cdots$ & - & - -.-- & - & $10-19-60$ & 15.1 & 55 & .03 & $\cdots$ & $\ldots$ & 24 & 12 & 15 & 5 & 147 \\
\hline $253 \ldots$ & $21 / 26-21 \mathrm{E} 1--$ & - & 618 & Below 275 & $7-22-55$ & $\ldots$ & $\ldots$ & .02 & $\ldots$ & .02 & 17 & 12 & 12 & 4 & 129 \\
\hline $254-\ldots$ & $21 / 28-23 \mathrm{Dl}-$ & U.S. Government & 150 & - & $4-25-51$ & $\ldots$ & 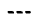 & $\therefore$ & $\ldots$ & $\therefore$ & 31 & 17 & 18 & 5.1 & 133 \\
\hline $255 \cdots$ & $21 / 28-23 \mathrm{Dl} 1-\ldots$ & -.e-do-........... & - ... & ................. & $10-19-60$ & 14.5 & 37 & .04 & $\ldots$ & $\ldots$ & 54 & $2=$ & 39 & 8.6 & 230 \\
\hline $256-\cdots$ & $21 / 28-23 \mathrm{Dl}=\ldots$ & 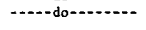 & --- & (1) & $5-3-61$ & 14.5 & 40 & .06 & $\cdots$ & $\cdots$ & 71 & 3) & 48 & 9.2 & 260 \\
\hline $257 \ldots$ & $21 / 30-3 \mathrm{E} 1=\ldots$ & A. Zickler....- & 451 & {$\left[\begin{array}{l}176-203 \\
296-319 \\
438-451\end{array}\right]$} & $10-19-60$ & 15.6 & 46 & .15 & $-\ldots$ & $-\cdots$ & 16 & 5.9 & 25 & 3.8 & 118 \\
\hline $258 \ldots .$. & $21 / 38-23 \mathrm{~A} 2-\cdots$ & Sprague--....... & 208 & $438-451$ & $7-1-55$ & $\cdots$ & $-\cdots$ & .12 & .01 & .08 & 18 & 12 & 11 & 3.1 & 118 \\
\hline \multicolumn{16}{|c|}{ T. $22 \mathrm{~N}$, , Ranges East } \\
\hline $9--.-$ & $22 / 25-13 \mathrm{~J} 2 \cdots$ & v. J. Barbre-.. & 118 & - n.enten & $10-19-60$ & 12.2 & 49 & .04 & $\ldots$ & $\ldots$ & 14 & 6.9 & 8.4 & 2.0 & 87 \\
\hline -... & $22 / 26-12 \mathrm{Bl}=\ldots$ & J. A. Molet-... & 78 & - & $3-6-56$ & $\ldots$ & $\ldots$ & $\ldots$ & $-\ldots$ & $\cdots$ & 70 & 31 & 45 & 8.6 & 245 \\
\hline $261-\ldots$ & $22 / 26-12 \mathrm{C} 2 \ldots$ & พ. E. HLIl-.... & 187 & $183-184$ & $1-23-53$ & $-\cdot-$ & -- & $\cdots$ & $\cdots$ & $\cdots$ & 55 & $2^{a}$ & 323 & 20 & 566 \\
\hline & $22 / 26-23 M 1-$. & Westmont Acres- & 448 & - & & $\ldots$ & --- & $-\cdots$ & $\ldots$ & $\ldots$ & 0 & 2 & 15 & 4.3 & 224 \\
\hline $263-\ldots$ & $22 / 26-24 \mathrm{Ll}=-$ & Soaplake-......... & 435 & $405-435$ & $7-22-55$ & $\ldots$ &.-- & .13 &..- &.-- & 15 & $1=$ & 20 & 4 & 156 \\
\hline $264-\cdots$ & $22 / 27-19 \mathrm{Nl}=-$ & 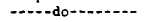 & 466 & $430-460$ & -- do- - & $\cdots$ & --- & .01 & $--\cdot$ & --- & 17 & 12 & 24 & 5 & 146 \\
\hline $265=\ldots$ & $22 / 27-23 \mathrm{R}_{1}=$ & E. W. Short--.- & 258 & $250-258$ & $4-30-50$ & $\ldots$ & 49 & .02 & .0 & $\ldots$ & 16 & 8.1 & 40 & 7. & 174 \\
\hline $266-\ldots$ & $22 / 33-27 \mathrm{E} 1-$ & M. C. Weber-.... & 305 & (n) & $5-1-62$ & 17.2 & 55 & .25 & $\therefore$ & $\ldots$ & 13 & 4.2 & 52 & 6.7 & 178 \\
\hline $267-\ldots$ & $22 / 43-32 \mathrm{~L} 1=\ldots$ & W. Hendrexson-- & 115 & $\begin{array}{l}80-115 \\
285-287\end{array}$ & $5-2-61$ & 9.5 & 52 & .03 & $\cdots$ & --- & 33 & 8.7 & 26 & .4 & 106 \\
\hline $268-\ldots$ & $22 / 45-19 \mathrm{c} 1 \cdots$ & Fairfleld (town) & 359 & {$\left[\begin{array}{l}340-343 \\
353-359\end{array}\right]$} & $10-31-62$ & 11.1 & 54 & .01 & .3 & $-\cdots$ & 24 & 6.4 & 12 & 1.5 & 116 \\
\hline \multicolumn{16}{|c|}{ T. 23 N., Ranges East } \\
\hline $269----$ & $23 / 28-36 \mathrm{E} 1---$ & v.s. Government & 187 & $175-187$ & $4-25-51$ & $\ldots$ & -- & -...- & $\cdots$ & $\ldots$ & 33 & 17 & 32 & 4.7 & 221 \\
\hline & $23 / 29-14 \mathrm{Jl}=-$ & v. Steven & 664 & $108-512$ & $8-10-54$ &..- & --- & .04 & .00 & .03 & & 11.8 & 19. & & 125 \\
\hline $271-\ldots$ & $23 / 29-23 \mathrm{Gl}-\ldots$ & J. Rolls -........ & 550 & ................ & $\cdots$ do-.. & -... & -.. & .06 & .01 & .03 & 12.8 & 13.7 & 24 & 5.5 & 156 \\
\hline $272 \ldots$ & $23 / 29-34 \mathrm{Bl}=\ldots$ & v. Stevens---..- & 1000 & $445-74,8$ & ---do--. & -... & -.. & .... & $\ldots$ & $-\ldots$ & 16.6 & 8.4 & 24 & 4.3 & 128 \\
\hline $273-\ldots$ & $23 / 37-29$ F1--- & H. Armstrong --- & 213 & $185-213$ & 5- $2-61$ & 8.9 & 38 & .05 & $\cdots$ & $\cdots$ & 40 & $10^{\circ}$ & 26 & 2.0 & 228 \\
\hline \multicolumn{16}{|c|}{ T. $24 \mathrm{~N}$, Ranges East } \\
\hline 274---- & $24 / 40-3 \times 1-\ldots$ & Wash. (State)-- & 440 & {$\left[\begin{array}{l}215-218 \\
400-440\end{array}\right]$} & $12-1-59$ & 14.4 & 45 & .20 & $\cdots$ & $\cdots$ & 23 & 9.7 & 18 & 1.7 & 149 \\
\hline $275 \ldots$ & $24 / 40-22 \mathrm{~L} 1-\ldots$ & v.s. Government & 345 & {$\left[\begin{array}{c}60-65 \\
335-345\end{array}\right]$} & $11-6-57$ &.-- &.-- & .12 & --- & --- & 29 & 11 & 15 & 2.8 & 148 \\
\hline $276 \cdots--$ & & 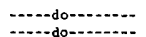 & $\ldots$ & (1) & $\begin{array}{r}9-23-59 \\
11-8-60\end{array}$ & 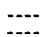 & $\begin{array}{l}45 \\
43\end{array}$ & .10 & $\ldots$ & $-\ldots$ & 30 & 10 & 16 & 3.0 & 148 \\
\hline
\end{tabular}

TABLE 1. - Chemical analyses of ground water in the basalt of the 


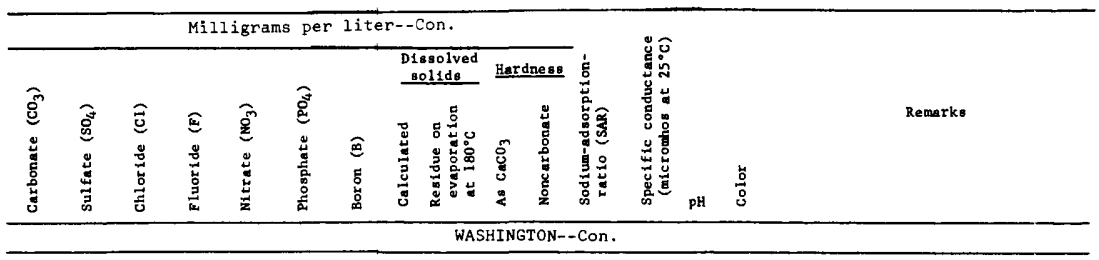

\begin{tabular}{|c|c|c|c|c|c|c|c|c|c|c|c|c|c|c|c|}
\hline $\begin{array}{l}0 \\
0\end{array}$ & $\begin{array}{l}24 \\
25\end{array}$ & $\stackrel{9}{9.5}$ & $\begin{array}{r}0.5 \\
.6\end{array}$ & $\begin{array}{r}0.2 \\
.2\end{array}$ & $-\ldots$ & $-\ldots$ & $\begin{array}{l}201 \\
224\end{array}$ & $\begin{array}{l}211 \\
218\end{array}$ & $\begin{array}{l}73 \\
71\end{array}$ & $\cdots$ & $\begin{array}{l}1.8 \\
2.0\end{array}$ & $\begin{array}{l}313 \\
314\end{array}$ & $\begin{array}{l}8.2 \\
8.2\end{array}$ & $\begin{array}{l}5 \\
5\end{array}$ & $\begin{array}{l}\text { Wash, WSB } 24 \text {. } \\
\text { Do, Two intervening anal. Elmilar. }\end{array}$ \\
\hline 0 & 21 & 13 & .3 & $200^{\circ 2}$ & .0 & $\cdots$ & 238 & $-\ldots$ & 127 & -- & .8 & 344 & 8 & $\ldots$ & $\begin{array}{l}\text { Do. TWO intervening anal. Himilar. } \\
\text { Wash, WSB } 8 \text {. }\end{array}$ \\
\hline$\cdots$ & 35 & 22 & 1 & $\cdots$ & $\cdots$ & $\cdots$ & $\cdots$ & 282 & 60 & $\cdots$ & 3.3 & 401 & 7.9 & $\cdots$ & Wash, WSB 8. Anal. Bur. Reclamation. \\
\hline 0 & 37 & 10 & .5 & .3 & $\cdots$ & .14 & 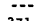 & 274 & 94 & $\cdots$ & 2.3 & 438 & 7.9 & $\cdots$ & Wash, WSB 8, Adams County. \\
\hline $\begin{array}{l}0 \\
0\end{array}$ & $\begin{array}{l}80 \\
65\end{array}$ & $\begin{array}{l}48 \\
32\end{array}$ & .7 & 15 & .02 & $\cdots$ & $\begin{array}{l}371 \\
323\end{array}$ & $\begin{array}{l}390 \\
337\end{array}$ & 207 & -- & $\begin{array}{l}1.2 \\
1.3\end{array}$ & $\begin{array}{l}602 \\
497\end{array}$ & $\begin{array}{l}7.8 \\
8.0\end{array}$ & 0 & Wash. WSB 24 . \\
\hline & & & & & & & & 331 & 152 & & & 471 & & 0 & \\
\hline 0 & 13 & 5.5 & .9 & .8 & --- & --- & 215 & 214 & 61 & -- & 2.0 & 287 & 8.0 & 5 & Do. \\
\hline 0 & 15 & 8.5 & .5 & 15 & .19 & --- & 259 & $\cdots$ & 150 & 0 & .9 & 392 & 7.3 & -- & Whitman County. \\
\hline 0 & 36 & 8 & .7 & 2.3 & .18 & $\cdots$ & 231 & 240 & 126 & $\cdots$ & .7 & 323 & 7.5 & 0 & Wash. WSB 24 . Grant County. \\
\hline--- & 12 & 7 & $\cdots$ & $\cdots$ & $\cdots$ & $-\ldots$ & $\cdots$ & 201 & 92 & $\cdots$ & 1.0 & $-\cdot-$ & 7.9 & -- & WIT B-237, no. 199 . Well 3 . \\
\hline$\because$ & 6 & 7 & --- & $\cdots$ & -... & $--\cdot$ & -- & 177 & 97 & -- & .5 & $\cdots$ & 7.6 & $\cdots$ & WIT B-237, no. 200. Well 5 . \\
\hline 8 & 11 & 6 & $\cdots$ & $\cdots$ & $\cdots$ & -. & $-\cdots$ & 221 & 87 & $\cdots$ & .6 & $\cdots$ & 8.1 & -- & WIT B-237, no. 203, We11 6 . \\
\hline 0 & 14 & 5.8 & .3 & 4.1 & $\cdots$ & .0 & 237 & 233 & 137 & $\cdots$ & .7 & 334 & 7.4 & $\cdots$ & Wash. WSB 8. Wel1 2 . \\
\hline 0 & 11 & 4.3 & .3 & 1.4 & $\cdots$ & $\cdots$ & 197 & $\cdots$ & 109 & $\cdots$ & .6 & 207 & -- & -- & Do. \\
\hline$\cdots$ & 6 & 7 & $\cdots$ & $\cdots$ &..- & .0 & $\cdots$ & 206 & 102 & $\cdots$ & .6 & $\cdots$ & 7.6 & $\cdots$ & WIT B-237, no. 201. \\
\hline 0 & 10 & 4.0 & .4 & 2.1 & .19 & $\cdots$ & 198 & 193 & 103 & $\cdots$ & .7 & 263 & 7.5 & 5 & Wash. WSB 24 . \\
\hline 3.0 & 8 & 7 & $\cdots$ & $\cdots$ & $\cdots$ & .01 & $\cdots$ & 195 & 94 & $\cdots$ & .5 & $-\overline{3}$ & 8.1 & -- & WIT B-237, no, 204, Well 4 . \\
\hline 0 & 31 & 26 & .5 & 22 & $\cdots$ & $\cdots$ & $\ddot{404}$ & 282 & 155 & -- & .6 & 399 & 7.5 & $--\cdot$ & Wash, WSB 8, Anal. Bur. Reclamation. \\
\hline 0 & & 27 & .6 & 12 & .18 & -..- & $\begin{array}{l}404 \\
505\end{array}$ & 407 & 238 & $\cdots$ & 1.1 & 630 & 7.9 & 5 & \\
\hline 0 & 130 & 37 & .4 & 11 & .17 & $\cdots$ & & 527 & 302 & $\cdots$ & 1.2 & 768 & 7.8 & 5 & Do. \\
\hline 0 & 10 & 5.0 & .3 & 6.3 & .08 & - & 176 & 177 & 64 & $\cdots$ & 1.4 & 231 & 7.5 & 5 & Do. \\
\hline 4 & 21.2 & 6.4 & $\cdots$ & $\cdots$ & $\cdots$ & .02 & $\cdots$ & 208 & 95 & -- & .5 & $\cdots$ & 7.7 & $\cdots$ & WIT B-237, no. 170. Lincoln County. \\
\hline 0 & 4.6 & 3.2 & .4 & 1.9 & .22 & $=$ & 134 & 132 & 63 & -- & .5 & 158 & 7.4 & 5 & Wash. WSB 24. Grant County. \\
\hline 0 & 137 & 45 & .5 & .6 & $\cdots$ & & -- & 568 & 302 & $\cdots$ & 1.1 & 792 & 7.5 & $\cdots$ & Wash. WSB 8. Anal, Bur, Reclation, \\
\hline 0 & 280 & 147 & $\cdots$ & --- & $\cdots$ & - & $-\cdots$ & $\cdots$ & 252 & -- & 8.9 & 1820 & 7.7 & $-\cdot$ & Do. \\
\hline$-\cdot$ & 14 & 8.9 & .9 & 9.9 & 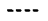 & & $\cdots$ & 212 & 99 & --- & .7 & 282 & 6.8 & -.. & Do. Casing not set to basqlt. \\
\hline 2.3 & 18 & 7 & $\cdots$ & $\cdots$ & $\cdots$ & .03 & $\cdots$ & 251 & 102 & $\cdots$ & .8 & $\cdots$ & 7.8 & $\cdots$ & WTT B-237, no. 197. City we 113 . \\
\hline 2.3 & 18 & 8 & $\cdots$ & $\cdots$ & ...- & .009 & $--\bar{x}$ & 236 & 92 & $\cdots$ & 1.0 & $\cdots$ & 7.9 & $\cdots$ & WIT B-237, no. 198. City well 2 . \\
\hline 0 & 17 & 6.1 & .9 & $\cdots$ & $\cdots$ & .0 & 230 & (1)- & 73 & $\cdots$ & 2.3 & 316 & $8 \cdot \frac{1}{2}$ & $-\cdot$ & Wash. WSB 8 . \\
\hline 0 & 11 & 7.5 & 1.0 & .1 & .05 & -1 & 266 & 239 & $\begin{array}{r}50 \\
118\end{array}$ & 0 & $\begin{array}{l}3.2 \\
1.0\end{array}$ & $\begin{array}{l}320 \\
359\end{array}$ & $\begin{array}{l}8.2 \\
7.3\end{array}$ & $-\overline{5}$ & $\begin{array}{l}\text { Lincoln County. } \\
\text { Wash. WSB } 24 \text {. Spokane County. }\end{array}$ \\
\hline 0 & 24 & 13 & $\cdot 3$ & 56 & .36 & $\cdots$ & & 285 & 118 & -- & 1.0 & & & 5 & Wash. WSB 24 . Spokane County. \\
\hline 0 & 4.6 & 3.0 & .5 & 9.3 & .41 & .00 & 173 & $\cdots$ & 86 & 0 & .6 & 220 & 7.2 & -- & \\
\hline 0 & 26 & 14 & .5 & 1.2 & $-\cdots$ & - & -- & 286 & 152 & -- & 1.1 & 427 & 7.4 & -- & Wash. WSB 8. Grant Co,Anal, Bur Rec1, \\
\hline -.. & 14 & 20 &.- & $\cdots$ & $\cdots$ & .02 & --- & 305 & 93 & $\cdots$ & .9 & $-\cdot$ & 7,9 & $\cdots$ & WIT B-237, no. 94 . \\
\hline$\cdots$ & 8.7 & 7.5 & $\cdots$ & $\cdots$ & 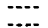 & .02 & -.. & 295 & 75 & $\cdots$ & 1.2 & $\cdots$ & 8.1 & -- & $\begin{array}{l}\text { WIT B-237, no. } 93 \text {. } \\
\text { WIT B-237, no, } 95 \text {. }\end{array}$ \\
\hline 0 & $\begin{array}{l}14 \\
12\end{array}$ & $\begin{array}{c}9.6 \\
10\end{array}$ & .3 & 17 & .09 & $-\cdots$ & 275 & $\begin{array}{l}295 \\
279\end{array}$ & $\begin{array}{r}75 \\
174\end{array}$ & -- & $\begin{array}{r}1.2 \\
.8\end{array}$ & 429 & $\begin{array}{l}7.9 \\
7.9\end{array}$ & --- & $\begin{array}{l}\text { WIT B-237, no. } 95 \text {. } \\
\text { Wash. USB } 24 \text {. Lincoln Co.Sand Interbed }\end{array}$ \\
\hline 0 & 11 & 3.0 & .5 & 0 & .00 & $-\cdots$ & 185 & 178 & 97 & $\cdots$ & 1.0 & 255 & 7.8 & 0 & Wash. WSB 24. Spokane County. \\
\hline 0 & 20 & 5.5 & .2 & .4 & $\cdots$ & -.- & 191 & 197 & 118 & -- & .6 & 284 & 7.9 & 5 & Wash. WSB 24. Spokane Co. We11 45-C. \\
\hline 2 & 21 & 5.5 & .4 & .0 & $\cdots$ & - & 206 & 204 & 117 & $\cdots$ & .6 & 294 & 8.3 & 5 & Do. \\
\hline 0 & 19 & 6.2 & .3 & .2 & -- & & 203 & 197 & 116 & $-\cdot$ & .6 & 291 & 8.0 & 5 & Do. Two intervening anal, sinilar. \\
\hline
\end{tabular}

Columbia River Group, Washington, Oregon, and Idaho - Continued 


\begin{tabular}{|c|c|c|c|c|c|c|c|c|c|c|c|c|c|c|c|}
\hline \multirow[b]{2}{*}{ 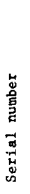 } & \multirow[b]{2}{*}{$\begin{array}{l}\text { Location } \\
\text { number } \\
\text { (s at end of } \\
\text { number } \\
\text { indicates } \\
\text { spring) }\end{array}$} & \multirow[b]{2}{*}{$\begin{array}{l}\text { Orner of well } \\
\text { or spring } \\
\text { (at time of } \\
\text { sampling) }\end{array}$} & \multirow[b]{2}{*}{$\begin{array}{l}\text { Depth } \\
\text { of } \\
\text { well } \\
\text { (feet) }\end{array}$} & \multirow[b]{2}{*}{$\begin{array}{l}\text { Depth of } \\
\text { water- } \\
\text { besring } \\
\text { zone (s) } \\
\text { (feet) }\end{array}$} & \multirow[b]{2}{*}{$\begin{array}{l}\text { Date } \\
\text { water } \\
\text { sample } \\
\text { collected }\end{array}$} & \multirow[b]{2}{*}{ 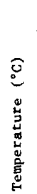 } & \multicolumn{8}{|c|}{ Milligrams per liter } & \multirow[b]{2}{*}{ 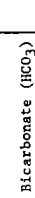 } \\
\hline & & & & & & & 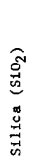 & 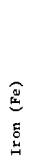 & 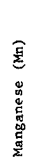 & 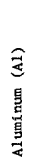 & 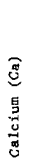 & 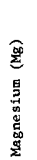 & 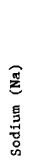 & $\begin{array}{l}\widehat{3} \\
5 \\
5 \\
5 \\
0 \\
0 \\
0 \\
0 \\
0 \\
0\end{array}$ & \\
\hline
\end{tabular}

\section{T. 24.N. Ranges East--Continued} 279-... 24/41-3N1--. (Fairchild AFB) -...

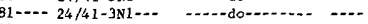

$288 \ldots .24 / 41-3 \mathrm{~N} \cdots$

1-- U.S. Government $274 \quad 204-209$

285-... 24/411-11N1-..

\section{T. 25 N., Ranges East}

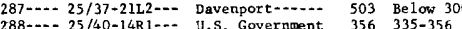

288-... 25/40-14R1-.. U.S. Government $356 \quad 335-356$

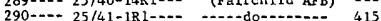

29i- 25/41-1R

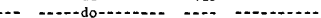

25/41-1061-..

295--.- 25/41-34B1--.

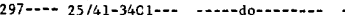

\section{T. $26 \mathrm{~N}$. Ranges East}

298--.. 26/31+32A1-.- Almira-......... 208 Below 60 $299-\ldots$ 26/33-18L1-.. Wilbur-
278-... 24/41-3N1- U.S. Government 410

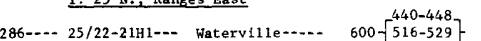

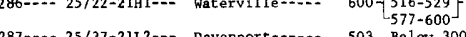

293-cer $115-150$

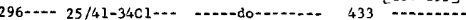

$\begin{array}{rrrrrrr}2-26-47 & \ldots & 51 & 0.02 & \ldots .- & \ldots . & 21\end{array}$

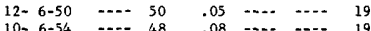

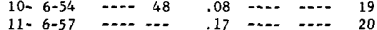

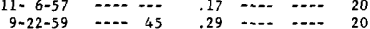

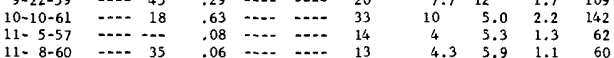

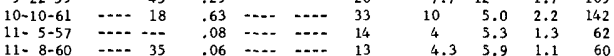

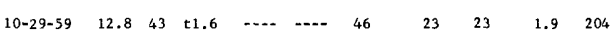

$\begin{array}{lllllllllll}5-1-62 & 13.9 & 42 & .07 & \ldots .- & \ldots .- & 17 & 8.7 & 25 & 8.0 & 128\end{array}$

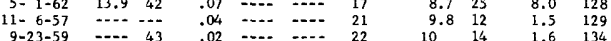

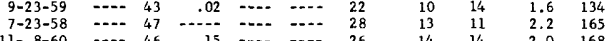

$\begin{array}{lllllllllll}11-8-60 & \ldots-2 & 46 & .15 & \ldots-. & \ldots-. & 26 & 14 & 14 & 2.0 & 168 \\ 11-6-57 & \ldots-2 & \ldots . & .03 & \ldots-. & \ldots .- & 41 & 14 & 12 & 2.3 & 144\end{array}$

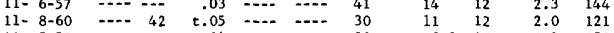

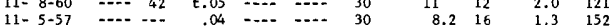

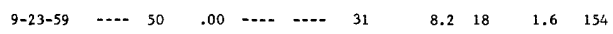

$\begin{array}{lllllllllll}10-30-56 & 19 & 45 & .18 & \ldots-. & \ldots .- & 33 & 11 & 14 & 1.3 & 122\end{array}$

$\begin{array}{lllllllllll}1-3-59 & 13.3 & 43 & 1.1 & \ldots . . & \ldots . & 28 & 16 & 30 & 3.8 & 200\end{array}$ OREGON

T. $1 \mathrm{~N}$. , Ranges East

300--.- 1N/1-34N4-.-- Commonwea1th--- $508 \quad 370-508$

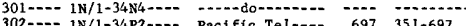
$302-\cdots-1 N / 1-34$ P2 - -2 Pacific Tel--- $697 \quad 351-697$ $304-\ldots$ 1N/13-3E1.... The Dalles-..- $201 \quad 180-201$ $305-\ldots$ 1N/13-3E1-... $306-\ldots$ 1N/13-4F1-...

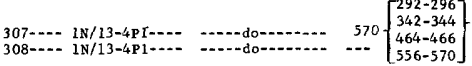

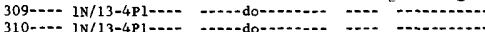

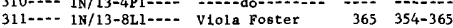

$312--.-1$ 1N/13-14Ml-.. Jack Martin-... $196 \quad 180-196$

313--- 1N/13-23D1- - Cherry H1l1 D1st, 301 -

314-... 1N/13-32G2 -.. Milton Yartin-- $427 \quad 330-336$

315--.- 1N/17-9p1-..- Waseo-........-.. $449\left[\begin{array}{l}267-284 \\ 442-449\end{array}\right]$

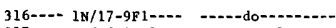

$317-\ldots$ IN/18-32Dl--- E. E. Shul1---- 157 Below 90

$318-\ldots-1$ 1N/25-13P1--- J. F. Barak-.... 237

$319-\cdots 1 \mathrm{~N} / 26-10 \mathrm{Al}=-$ W. Doherty--...- $376 \quad \ldots$

$320-\cdots-1 N / 27-24 R 1 \cdots-$ A. J. Vey-.....-

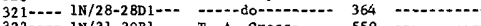

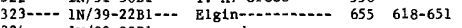

\begin{tabular}{|c|c|c|c|c|c|c|c|c|c|c|}
\hline $1-9-47$ & 12.2 & 35 & 0.2 & -..- & $\ldots$ & 45 & 2 & \multicolumn{2}{|c|}{$\cdots 174-\cdots$} & - \\
\hline $3-9-55$ & 12.2 & $\ldots$ & $\cdots$ & $\ldots$ & $\ldots$ & $\ldots$ & $-\ldots$ & & & 116 \\
\hline $4-3-51$ & & 43 & .19 & 0.05 & & 64 & 3.7 & $\cdots-18$ & & 117 \\
\hline $7-31-58$ & 27.8 & 95 & t. 04 & .00 & 0.0 & 16 & 4.6 & 62 & 11 & 234 \\
\hline $7-26-30$ & 17.2 & 70 & .02 & $\cdots$ & $-\cdots$ & 18 & 8.2 & 44 & 6.2 & 196 \\
\hline - n & - & $\cdots$ & .06 & & & $\cdots$ & $\cdots$ & & & 171 \\
\hline $0-27-60$ & 16.7 & 62 & .07 & $\cdots$ & & 37 & 14 & 39 & 9.3 & 249 \\
\hline $3-1$ & 20.0 & $\cdots$ & .09 & & .2 & $\cdots$ & $\cdots$ & -... & & 158 \\
\hline $6-25-54$ & $\cdots$ & 80 & 0 & 0 & & 17 & 12 & $\cdots$ & & 160 \\
\hline $7-3$ & 20.0 & 74 & t.06 & .00 & 0 & 17 & 6.8 & 44 & 8.0 & 190 \\
\hline $6-22-61$ & 20.0 & 66 & .04 & $\cdots$ & $\ldots$ & 26 & 10 & 44 & 8.8 & 194 \\
\hline $7-31-58$ & .... & 86 & .03 & .00 & .0 & 17 & 6.1 & 56 & 10 & 224 \\
\hline $7-30-58$ & 16.8 & 74 & $t .00$ & .00 & .0 & 27 & 13 & 15 & 5.0 & 173 \\
\hline $7-26-30$ & 17.8 & 68 & .01 & $\cdots$ & & 15 & 8.9 & 11 & .0 & 109 \\
\hline $7-30-58$ & 22.2 & 84 & t. .03 & .0 & 1.0 & 15 & 2.9 & 41 & 7.2 & 167 \\
\hline $6-1-54$ & - & 71 & t. 05 & 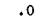 & & 27 & 12 & 19 & 4.5 & 160 \\
\hline $6-$ & 2 & 61 & .0 & .. & $\cdots$ & 27 & 13 & 15 & & 161 \\
\hline$-\cdots d$ & 5 & 56 & .05 & $\cdots$ & & 22 & 12 & 23 & & 154 \\
\hline $5-10-67$ & & 38 & --.- & .... & -- & 17 & 5.6 & 34 & 5.9 & 126 \\
\hline & 8 & 58 & $\cdots$ & $\cdots$ & & 71 & 38 & 54 & 12 & 252 \\
\hline$\cdots-d$ & 20.6 & 63 & $\cdots$ & $\cdots$ & & 8 & 1.6 & 48 & 4.5 & 128 \\
\hline $4-28-53$ & 17.8 & 70 & .2 & $\ldots$ & & 15 & 5.7 & 40 & & 163 \\
\hline $4-27$ & & 66 & .1 & & & 36 & 12 & 22 & & 154 \\
\hline $5-10-57$ & 11.1 & 38 & +03 & $\cdots$ & & 5.2 & 1.4 & 21 & 5. & 82 \\
\hline $3-17-67$ & & o & & & & 6 & & & & c 82 \\
\hline
\end{tabular}

TABLE 1. - Chemical analyses of ground water in the hasalt of the 


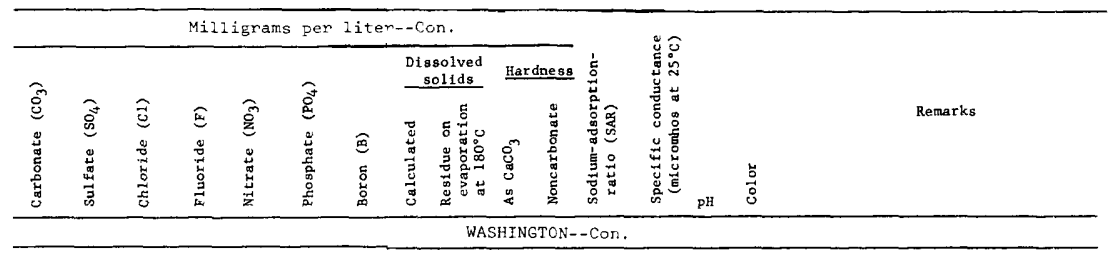

\begin{tabular}{|c|c|c|c|c|c|c|c|c|}
\hline 0 & 11 & 2.8 & 0.2 & 0.1 & $\ldots$ & - & - & 163 \\
\hline 0 & 11 & 2,2 & .2 & .3 & - & $-\cdots$ & 171 & 164 \\
\hline 0 & 11 & 2.6 & .3 & .4 & $\ldots$ & $\ldots$ & 168 & 164 \\
\hline 0 & 11 & 2.2 & .3 & .4 & $\ldots$ & $\ldots$ & $\cdots$ & 154 \\
\hline 0 & 12 & 2.2 & .4 & 2.3 & $\ldots$ & -... & $\lfloor 57$ & 156 \\
\hline 0 & 14 & 3.5 & .2 & 3.2 & $\ldots$ & -..- & 160 & 162 \\
\hline 0 & 5.8 & 1.0 & .2 & 6.0 & - & . & $\cdots$ & 110 \\
\hline 0 & 6.6 & 2.2 & .2 & 6.2 & & & 105 & 107 \\
\hline
\end{tabular}

$\begin{array}{rrrrrr}90 & \cdots & --- & 220 & -\cdots & - \\ 88 & \cdots & 0.6 & 215 & 7.7 & 2 \\ 86 & \cdots- & .6 & 219 & 7.9 & 4 \\ 85 & \cdots- & .6 & 214 & 7.6 & 5 \\ 82 & \cdots- & .6 & 208 & 7.8 & 0 \\ 125 & \cdots- & .2 & 262 & 7.8 & 5 \\ 52 & \cdots-. & .3 & 129 & 7.5 & 5 \\ 50 & \cdots- & .4 & 135 & 7.9 & 5\end{array}$

Wash, WSB 24, We11 2.

Do.

Do.

Do.

Do. Thirteen intervening anal.similar.

Wash WSB 24 , Well $37-C$ and $L$.

Do. Two intervening anal. simf lar.

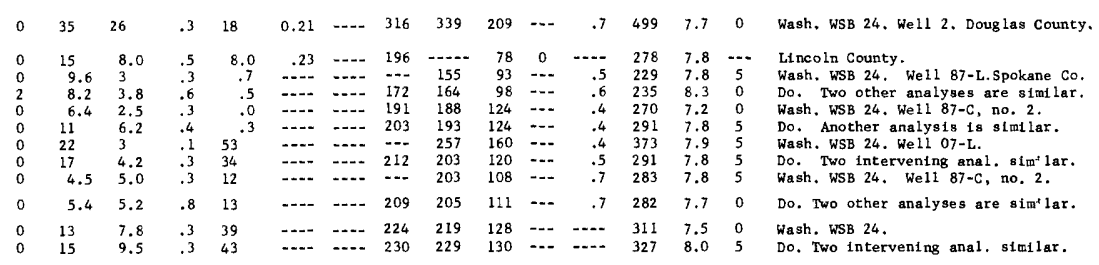

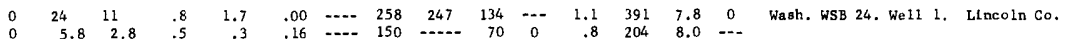

OREGON

\begin{tabular}{|c|c|c|c|c|c|c|c|c|c|c|c|c|c|c|c|}
\hline .... & 13 & 308 & .... & ....- & -..-- & $\ldots$ & -- & - & 119 & 0 & $\ldots$ & $\ldots$ & 7.8 & $\ldots$ & WSP-1619-0.Anal.Chat lton Lab. Mr1tnomah Co \\
\hline ... & $-\ldots$ & 400 &.-- & -...-- & $\ldots$ & -...- & -- & $\ldots-$ & 290 & --- & $\ldots$ & 1510 & 7.1 & -- & Do. Used as supply and recharge well. \\
\hline 0 & 9.8 & 328 & 0.6 & -...- & $\ldots$ & $\ldots$ & 697 & $\ldots$ & 176 & $\ldots$ & $\ldots$ & $\ldots$ & 7.9 & $\ldots$ & WSP-1619-0. Ana 1. Char1ton Lab. \\
\hline 0 & 1.5 & 7.5 & 1.6 & $-\ldots$ & 0.00 & -..- & 314 & 296 & 59 & 0 & 3.5 & 378 & 7.9 & 0 & Wasco County. \\
\hline$-\ldots$ & 12 & 6.0 & $-\ldots$ & 0.05 & $\ldots$ & $\ldots$ & ... & 249 & 79 & $\cdots$ & 2.2 & $\ldots$ & $-\ldots$ & - & WSP-659-B. City Hall well. \\
\hline$-\ldots$ & 29 & $\ldots$ & 1.0 & $\cdots$ & 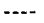 &.-- & $\cdots$ & $-\cdots$ & --- & $\cdots$ & $\cdots$ & --- & $\cdots$ & $\cdots$ & Anal. by Charlton Laboratories \\
\hline$m-$ & 28 & 10 & .7 & .5 & $\cdots$ & $\cdots$ & 328 & $\cdots$ & 152 & 0 & 1.4 & 470 & 7.7 & 0 & WSP-1594-E. Jordan street well. \\
\hline -... & 23 & --... & .6 &..-- & -- & -.. & -- & $\ldots$ & $\cdots$ & -- & & $\ldots$ & --- & $<.5$ & Marx we 11 . \\
\hline 0 & 15 & 6.4 & 1.1 & $\ldots$ & .05 & .. & 262 & 2195 & 77 & -- & $\cdots$ & $\cdots$ & 7.6 & & Anal. Oregon Board of Health. \\
\hline 0 & 10 & 6.0 & 1.0 & .0 & .00 & ..- & 260 & 249 & 70 & 0 & 2.3 & 335 & 8 & 0 & WSP-1594-E. \\
\hline 6 & 31 & 6.0 & .9 & .1 & $\ldots$ & ... & 295 & 296 & 108 & 0 & 1.9 & 402 & 8.5 & 0 & Do. \\
\hline 0 & 2.5 & 7.0 & 1.6 & .0 & .10 & $\ldots$ & 296 & 276 & 68 & 0 & 3.0 & 370 & 7.8 & 0 & \\
\hline 0 & 6.6 & 6.5 & .2 & .0 & .24 & $\ldots$ & 232 & 211 & 121 & 0 & .6 & 300 & 7.5 & 0 & \\
\hline$\ldots$ & 2.6 & 5.0 & .71 & $\ldots$ & $\ldots$ & -..- & $\cdots$ & 165 & 74 & $\ldots$ & 5 & -..- & -- & $\cdots$ & WSP- $659-B$. \\
\hline 0 & 2.4 & 6.0 & .9 & .0 & .00 & $\cdots$ & 241 & 228 & 49 & 0 & 2.5 & 279 & 8.5 & 0 & \\
\hline 0 & 12 & 12 & .5 & 1.7 & $\ldots$ & 0.05 & 239 & 229 & 117 & 0 & .8 & 322 & 7.4 & 5 & Sherman County. \\
\hline 0 & 12 & 12 & .5 & 1.9 & .-- & & 231 & 228 & 120 & 0 & 8 & 314 & 7.7 & 0 & \\
\hline 0 & 11 & 12 & .7 & .3 & $\ldots$ &..- & 218 & 213 & 104 & 0 & 1.0 & 303 & 8.0 & 0 & \\
\hline 0 & 24 & 14 & .8 & $\cdots$ & $\ldots$ & $\ldots$ & 201 & 181 & 66 & 0 & 1.6 & 292 & 7.9 & $\cdots$ & USGS Hydrologic At las HA- 387 . Morrow Co. \\
\hline 0 & 120 & 91 & .4 & - & $\ldots$ & & 568 & 561 & 334 & 127 & 1.2 & 891 & 7.9 & ... & $\mathrm{HA}-387$. \\
\hline$\ldots$ & .2 & 9 & .9 & & 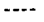 & & 210 & 210 & 26 & $\cdots$ & 4 & 258 & 8.6 & $\cdots$ & Do. \\
\hline 0 & .6 & 15 & .8 & .4 & -... & .23 & 233 & 225 & 61 & 0 & 2.2 & 285 & 8.1 &.- & WSP-1620. \\
\hline 0 & 26 & 20 & .4 & 9.9 & $\ldots$ & .00 & 273 & $-\ldots$ & 139 & 13 & 8 & 378 & 7.8 &.- & Umat 11 a county. \\
\hline 0 & 3.5 & .8 & .4 & .1 & -1 & $\cdots$ & $\cdots$ & 111 & 19 & 0 & 2.1 & 140 & 8.2 & $\cdots$ & WSP-1597. Wel1 3 . Union Count? \\
\hline-- & 3.5 & .8 & .42 & .01 & .16 & & $\cdots$ & 130 & 21.2 & -- & 1.5 & 107 & 8.4 & 1 & Anal. Oregon Board of Health. \\
\hline
\end{tabular}

Columbia River Group, Washington, Oregon, and Idaho - Continued 


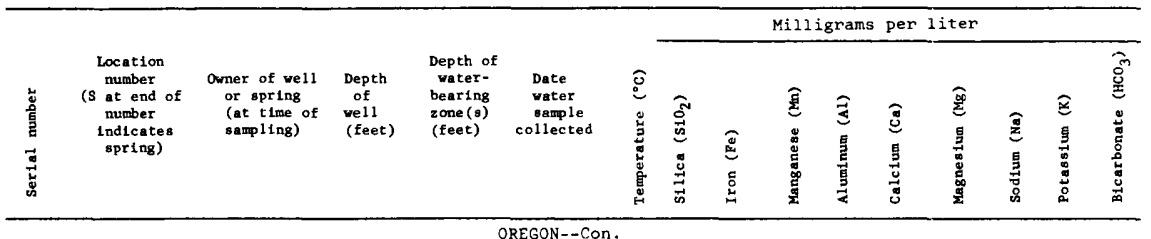

OREGON--CON.

\section{T. 1 N., Ranges Hest}

$325 \ldots 1 \mathrm{~N} / 1 \mathrm{~W}-20 \mathrm{H} 1 \ldots$ C. E. ... $326-\ldots-1 \mathrm{~N} / 2 \mathrm{~W}-24 \mathrm{Jl} 1--$ Somerset West$327-\ldots-1 \mathrm{~N} / 3 \mathrm{~W}-1 \mathrm{~K} 2 \ldots$ North Plains.$328--1 \mathrm{~N} / 3 \mathrm{~W}-1 \mathrm{~K} 2-\cdots$ -

\section{T. 2 N., Ranges Bast}

$330----2 N / 11-1 M 1----$ Moster-..--.--

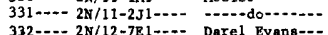
332-... 2N/12-7E1--.- Darel Evans-$334--2 \mathrm{~N} / 13-32 \mathrm{~J} 3-.-$ Chenowith Irrig. $335 \ldots 2 \mathrm{~N} / 14-31 \mathrm{P} 1-\ldots$ U.S. Government $336 \ldots 2 \mathrm{~N} / 23-17 \mathrm{R} 1-\ldots$ H. Hynd--..-$337---2 \mathrm{~N} / 25-28 \mathrm{DI}---\mathrm{C}_{3}$

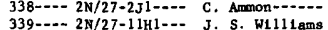
$339-\ldots 2 \mathrm{~N} / 27-11 \mathrm{HL}---$ J. S. W1111ams 340 -... 2N/27-14M1 -..- McCarty--....$341-\ldots-2 N / 27-26 L 1--$ R. Proudfoot-342--- 2N/32-2N1--- Pendleton---.$343-\cdots-2 \mathrm{~N} / 32-2 \mathrm{R}$

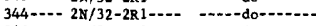

$345-\ldots$ 2N/32-2R1-...

$346--2 \mathrm{~N} / 32-2 \mathrm{R} 1-\mathrm{-}$ 348---- 2N/32-10F1-.- Pendleton-..-.

$349-\ldots$ 2N/32-1OF1-.- - -

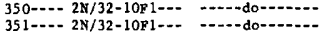

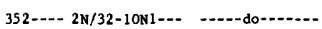

353---- 2N/32-10N1--- --.--do-...-..-

$354-\ldots-2 \mathrm{~N} / 32-35 \mathrm{HI}-\cdots$ John Crow-...$\begin{array}{lll}355----2 N / 33-14 G 1--- & \text { Pendleton--:-- } \\ 356---2 \mathrm{~N} / 33-33 \mathrm{~N} 1=- & \text { Guy Mueller--- }\end{array}$

\section{T. $3 \mathrm{~N}$., Ranges East}

357---. 3N/17-31N1-D. Rufus-.......-. $358---$ 3N/21-28D1-.- Arl1ngton--.-$359-\ldots$ 3N/21-28D1-.. $361 \ldots-\ldots$ S $/ 26-5 \mathrm{Ml} \ldots$.... 0 . J. Heliberg $362-\ldots$ 3N/26-10N1 -.. B. Cramer -.... $363 \ldots-$ 3N/32-22C1-.. George Mumm... $364 \ldots . . .3 N / 37-18413 .-$. $364-\ldots . . .3 \mathrm{~N} / 37-18 \mathrm{H} 1 \mathrm{s--}$ H. B. G16bon--

\section{T. 4 N., Ranges East}

366--- 4N/22-35C1--- U.P, Ratlway-$367 \ldots . .5 \mathrm{~N} / 24-22 \mathrm{G} 1 \ldots$ U.S. Government

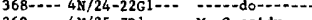
$369-1-4 \mathrm{~N} / 25-7 \mathrm{R} 1--$ men:-..--

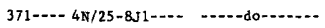

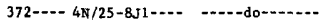
$373-\ldots$ 4N/27-5B1-... U.S. Government 374---- 4N/27-5B1 -...- -..--do-.....-$3745-1 \mathrm{~N} / 27-5 \mathrm{~B} 1 \mathrm{-}-\mathrm{-}$ $376-.-4 \mathrm{~N} / 27-5 \mathrm{~B} 1$

\begin{tabular}{|c|c|c|c|c|c|c|c|c|c|c|c|c|}
\hline 480 & $396-480$ & $5-17-51$ & 13.9 & 52 & to.13 & $\ldots$ & $\ldots$ & 37 & 2.7 & 68 & 11 & 174 \\
\hline & $480-5$ & $10-2$ & & 31 & $\cdots$ & ...- & & 4290 & 83 & 2350 & 122 & 13 \\
\hline 71 & $386-710$ & $3-$ & 15. & 49 & .0 & .. & & 15 & 7.9 & 31 & 9.0 & 136 \\
\hline$=-$ & . & $10-24-67$ & 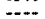 & 50 & .15 & .01 & $<0.02$ & 11.5 & 5.2 & 35 & 5.5 & c131 \\
\hline 301 & $261-262$ & $6-19-51$ & 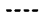 & 42 & .12 & & & 8.4 & 4.1 & 7.7 & 1.8 & 62 \\
\hline
\end{tabular}

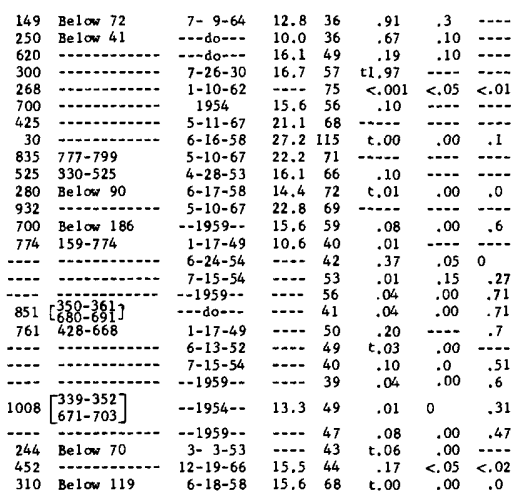

$\begin{array}{lllll}30 & 24 & 17 & 4.1 & 158\end{array}$ $\begin{array}{lllll}30 & 24 & 17 & 4.1 & 158 \\ 38 & 28 & 14 & 4.3 & 161\end{array}$ $\begin{array}{lllll}20 & 14 & 19 & 3.7 & 164 \\ 48 & 31 & 15 & 3.8 & 194\end{array}$ $\begin{array}{lllll}48 & 31 & 15 & 3.8 & 194 \\ 21 & 12.7 & 38 & 10 & c 187\end{array}$ $\begin{array}{rrrrr}24 & 14 & 27 & 4.0 & 157 \\ 3.9 & .7 & 73 & 8.8 & 164\end{array}$ $\begin{array}{lllll}1.6 & .0 & 90 & 5.6 & 114\end{array}$ $\begin{array}{lllll}17 & 4.5 & 33 & 9.7 & 160 \\ 14 & 7.5 & 32 & 9.0 & 161\end{array}$ $\begin{array}{lllll}25 & 12 & 30 & 7.2 & 198\end{array}$ $\begin{array}{ccccc}22 & 11 & 22 & 5.4 & 163 \\ 26 & 8.5 & 30 & 7 & \ldots .\end{array}$ $\begin{array}{rrlrr}27 & 8.5 & 30 & 7 & ---- \\ 26 & 7.6 & --31---- & 130\end{array}$ $26,18,60, \ldots-\ldots$ $\begin{array}{lllll}8.7 & 1.2 & -72.5-\ldots & \ldots . . \\ 9.3 & 2.2 & 64 & 9 & -. .\end{array}$ $\begin{array}{rrrrr}9.3 & 2.2 & 64 & 9 & -.-\end{array}$ $31 \quad 10.4 \quad--24-\cdots-149$ $\begin{array}{lllll}32 & 12 & 30 & 5.2 & 220\end{array}$ $\begin{array}{lllrr}37 & 12.6 & --.41 .1--. & --- \\ 38 & 13 & 33 & 5.3 & 162\end{array}$ $\begin{array}{lllll}38 & 13 & 33 & 5.3 & 162\end{array}$ $\begin{array}{lllll}30 & 8 & 39 & 6.3 & 147\end{array}$ $\begin{array}{rrrrr}9.2 & 2.8 & 70 & 9.3 & 147 \\ 2 . & 6.8 & 16 & .5 & 136\end{array}$ $\begin{array}{rrrrr}22 & 6.8 & 16 & .5 & \text { c138 } \\ 20 & 8.8 & 23 & 4.8 & 154\end{array}$

\begin{tabular}{|c|c|c|c|c|c|c|c|c|c|c|c|c|}
\hline 272 & $141-272$ & $10-1-62$ & $-\cdots$ & 50 & $<.001$ & $<.05$ & $<.01$ & 41 & 25.1 & 15 & 3 & $c 213$ \\
\hline 619 & $576-600$ & $2-11-55$ & 18.3 & 72 & .03 & 0 & $\cdots$ & 7.2 & .6 & 86 & 11 & 205 \\
\hline ... & - n- & $9-14-62$ & $\cdots$ & $\cdots$ & .0 & .3 & . & 4.0 & .3 & 107 & 9.7 & c200 \\
\hline 790 & $460-783$ & $5-9-67$ & $\cdots$ & 61 & $-\cdots$ & $\cdots$ & $\cdots$ & 3.0 & .6 & 106 & 15 & 209 \\
\hline 950 & . & $5-11-67$ & 23.3 & 78 & -.... & $\ldots$ & $\ldots$ & 9.0 & 2.9 & 57 & 12 & 176 \\
\hline 666 & - & -..do... & 23.3 & 79 & $\ldots$ & $\ldots+m$ & --- & 9.4 & 3.1 & 56 & 10 & 168 \\
\hline 400 & - & $3-3-53$ & $\cdots$ & 49 & .11 & .00 &.--- & 28 & 13 & 43 & 7.6 & 186 \\
\hline 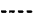 & -...- & 4- $1-54$ & 34.5 & 68 & t. 20 & $\ldots$ & --- & 14 & 3.5 & 133 & 7.6 & 46 \\
\hline 97 & $89-97$ & $7-27-61$ & 10.0 & 66 & .30 & --- & .... & 12 & .7 & 95 & 9.4 & 49 \\
\hline
\end{tabular}

\begin{tabular}{|c|c|c|c|c|c|c|c|}
\hline 305 & $240-305$ & $6-24-65$ & 15.6 & 47 & .53 & $\ldots$ & $\ldots$ \\
\hline 100 & -...... & $11-11-42$ & $\cdots$ & 43 & .05 & -- & \\
\hline & - & 5- 9-67 & 16.7 & 50 & & $\ldots$ & - \\
\hline 85 & Below 36 & $6-17-58$ & 18.3 & 55 & t. 71 & .00 & .0 \\
\hline 178 & $40-178$ & $2-1-65$ & $\cdots$ & 49 & .10 & 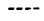 & \\
\hline 350 & {$\left[\begin{array}{l}138-144 \\
200-212\end{array}\right]$} & $10-30-64$ & 18.9 & 53 & .23 & & \\
\hline 585 & $539-585$ & $1-9-65$ & 20.0 & 56 & .07 & & \\
\hline 710 & $698-710$ & $3-30-62$ & 21.2 & 75 & & .0 & \\
\hline-- & & $4-22-63$ & $\cdots$ & 74 & .06 & .0 & \\
\hline 10 & $\ldots$ & $5-26-64$ & 21.2 & 71 & .11 & .0 & \\
\hline & 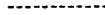 & $8-16-65$ & -- & 70 & .00 & & \\
\hline
\end{tabular}

\begin{tabular}{lcccc}
17 & 7.1 & 78 & 10 & 205 \\
36.8 & 21.4 & \multicolumn{2}{l}{$--69.8-.-$} & 244 \\
30 & 20 & 64 & 4.5 & 258 \\
32 & 11 & 97 & 6.0 & 256 \\
19 & 8.9 & 88 & 9.6 & 225 \\
14 & 3.1 & 89 & 9.4 & 198 \\
3.5 & .7 & 83 & 10 & 194 \\
1.5 & .4 & 74 & 11 & 170 \\
1.5 & .9 & 72 & 11 & 169 \\
2.0 & .3 & 72 & 11 & 176 \\
1.2 & .3 & 71 & 10 & 169
\end{tabular}

TABLE 1. - Chemical analyses of ground water in the basalt of the 


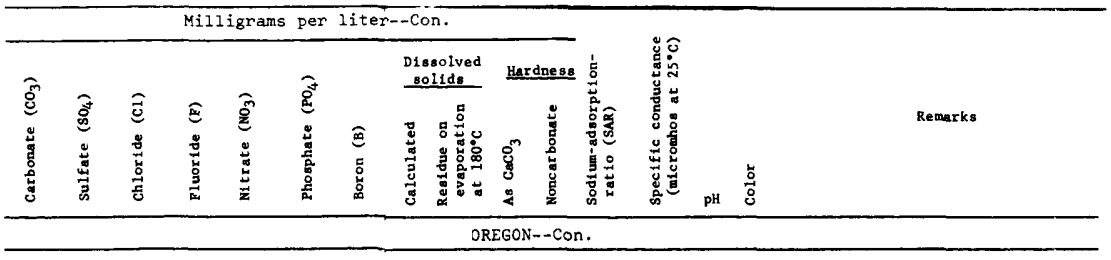

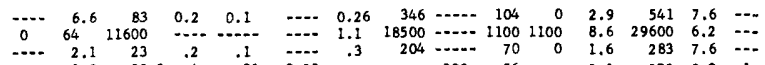
$\begin{array}{ccccccccccccccc}\ldots . . & 2.1 & 23 & .2 & .1 & \ldots . . & .3 & 204 & \ldots . . & 70 & 0 & 1.6 & 283 & 7.6 & \ldots \\ \ldots . . & 1.8 & 22.2 & .4 & <.01 & 0.22 & \ldots . . & \ldots . . & 203 & 56 & \ldots . & 2.1 & 272 & 8.0 & 1 \\ \ldots & 1.4 & 2.3 & .1 & .1 & \ldots . . & \ldots . . & 99 & \ldots . . & 38 & 0 & .6 & .99 & 7.4 & \ldots\end{array}$
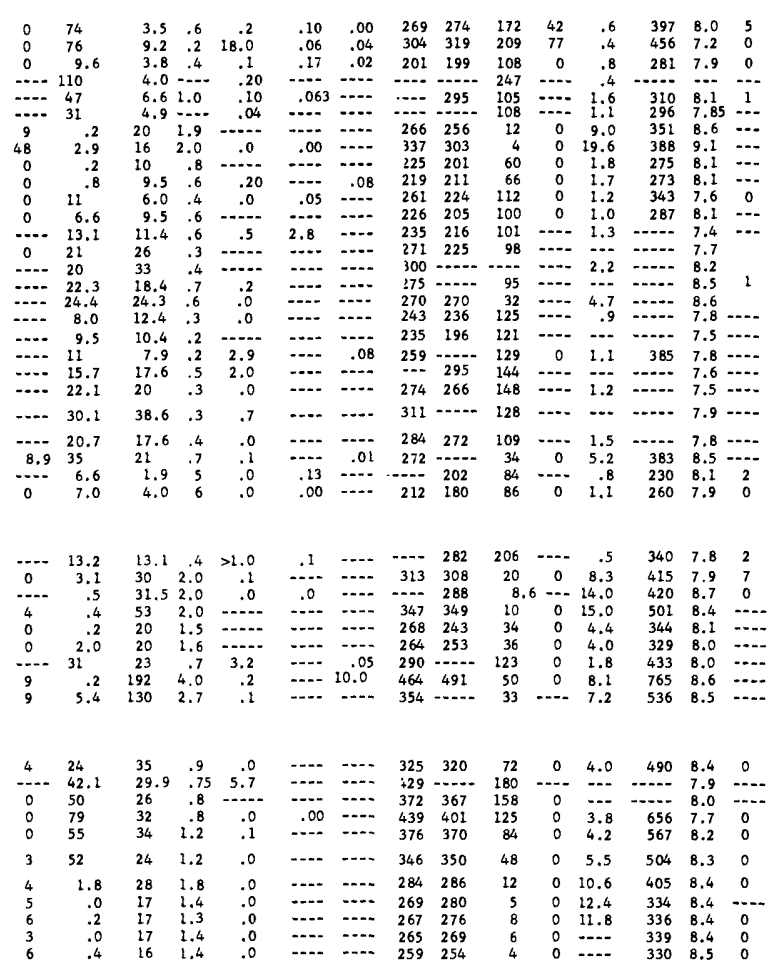

vSP-1697. Washington County. Density 1.012, Bromide 17; Iodide $2.2 \mathrm{mg} / 2$. WSP-1697. Anal. Oregon Board of Health.
WSP-1697.

Well no. 1. Hasco County.

Well no. 2

WSP-659-B.

Anal. Oregon Board of Heai th.

HA-3B7. Morrow County.

DA-3B7 Morrow County.

Dretled in rising

HA-3B7. Umatilla County.

St1liman Park well. Anal.consult.engrs. WSP-1690. Byers St,well, Char1,anal.

WSP-1690. Byers St.well,Charl, anal. Anal. 2962 rept. of consult. engrs.

Round-Up Park.Anal. Charlton Labs.

Anal. Chariton Laboratories.

Anal. 1962 rept. of consult. engrs. Twenty-first st,well. Anal Chariton.

Anal.1962 rept, of consult. engrs.

WSP-1620. city well 7.Anal.Oreg. Boerd Health.

Firat Rufus well. Anal. by Oregon

Boerd of Heaith. Sherman County.

Gilliam County.

Anal. Oreg. Bosrd of Health.

HA-3B7. Morrow County.

Do.

WSP-1620. Umatilis County.

WSP-1620. Bingham Springs.

Forest Service Guerd Station.

Gililam County.

Ana1. Charlton Lab. Morrow County, HA-3B7.

Old Boardman well.

New well. Sample depth 350 feet.

New well. Sampled after completion.

Umatilla Ordnance Depot vell no. 6 .

Columbia River Group, Washington, Oregon, and Idaho - Continued 


\begin{tabular}{|c|c|c|c|c|c|c|c|c|c|c|c|c|c|c|c|}
\hline \multirow[b]{2}{*}{ 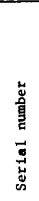 } & \multirow[b]{2}{*}{$\begin{array}{l}\text { Location } \\
\text { number } \\
\text { (s at end of } \\
\text { number } \\
\text { 1ndicates } \\
\text { spring) }\end{array}$} & \multirow[b]{2}{*}{$\begin{array}{l}\text { Owner of well } \\
\text { or spring } \\
\text { (at time of } \\
\text { sampling) }\end{array}$} & \multirow[b]{2}{*}{$\begin{array}{l}\text { Depth } \\
\text { of } \\
\text { well } \\
\text { (feet) }\end{array}$} & \multirow[b]{2}{*}{$\begin{array}{l}\text { Depth of } \\
\text { water- } \\
\text { bearing } \\
\text { zone }(s) \\
\text { (feet) }\end{array}$} & \multirow[b]{2}{*}{$\begin{array}{l}\text { Date } \\
\text { water } \\
\text { sample } \\
\text { collected }\end{array}$} & \multirow[b]{2}{*}{ 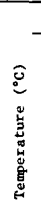 } & \multicolumn{9}{|c|}{ Milligrams per liter } \\
\hline & & & & & & & 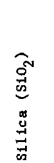 & $\begin{array}{l}\widehat{O} \\
\stackrel{\Xi}{E} \\
\stackrel{5}{5}\end{array}$ & 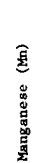 & 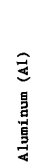 & 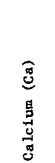 & 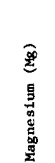 & 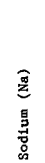 & 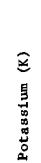 & 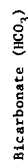 \\
\hline
\end{tabular}

OREGON--CON.

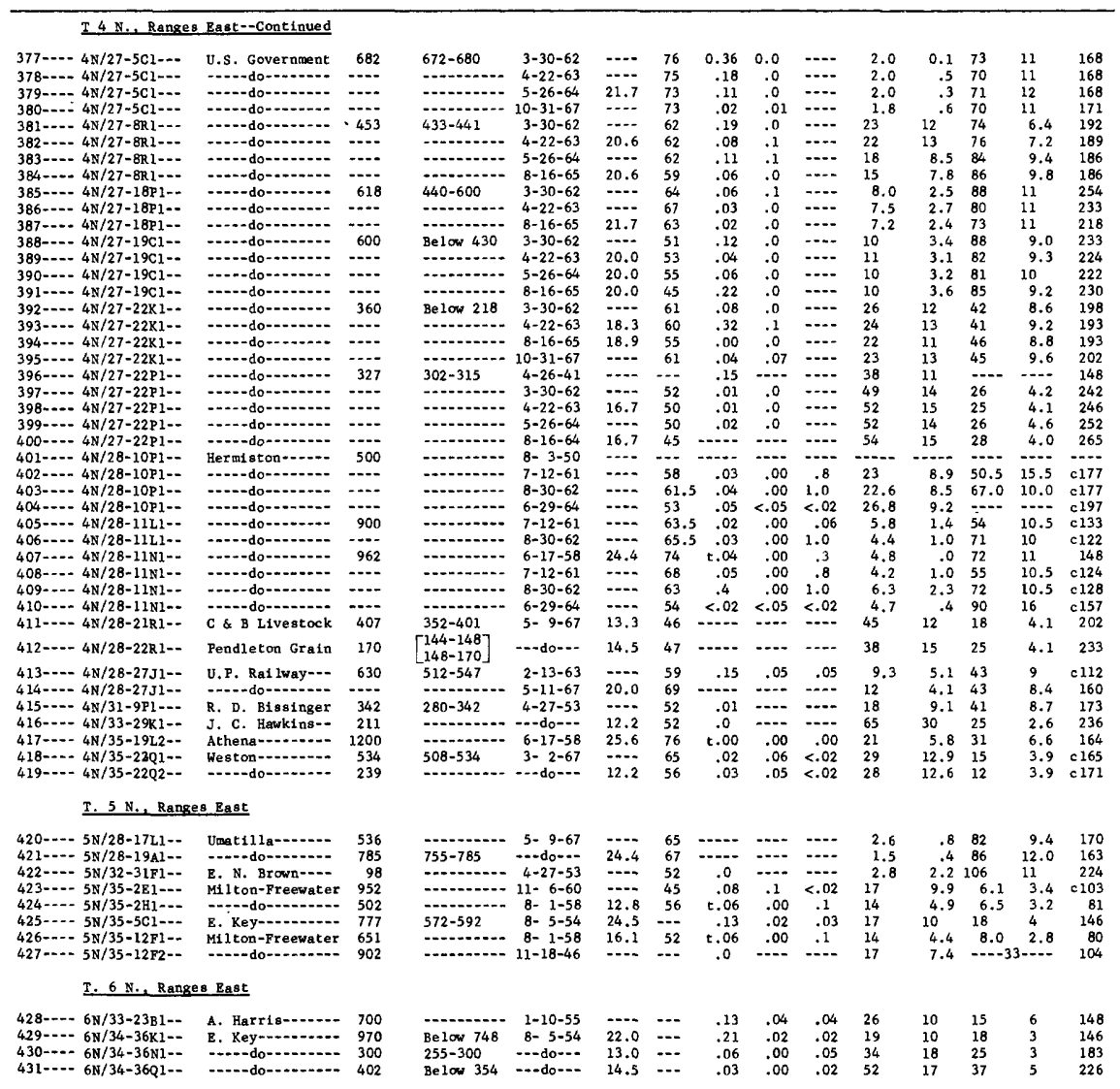

TABLE 1. - Chemical analyses of ground water in the basalt of the 


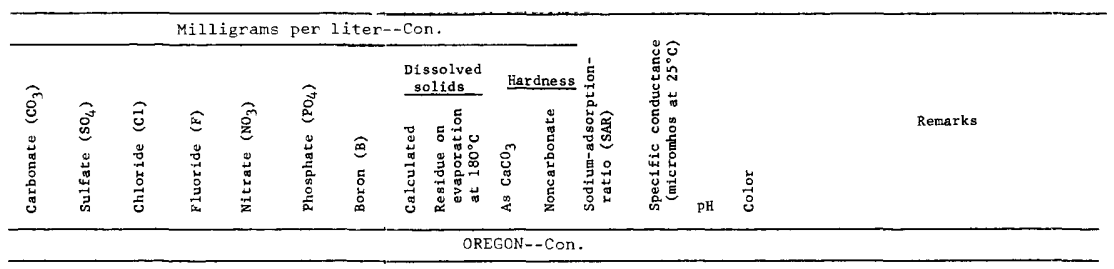

\begin{tabular}{|c|c|c|c|c|c|c|}
\hline 6 & 0.4 & 17 & 1.4 & 0.4 & $\ldots$ & .... \\
\hline 5 & 0 & 17 & 1.3 & .0 & $\ldots$ & --- \\
\hline 6 & .2 & 17 & 1.4 & .0 & $\ldots$ & -- \\
\hline 4 & .6 & 18 & 1.3 & .1 & $\ldots$ &.-- \\
\hline 0 & $94^{\circ}$ & 12 & 1.1 & .0 & $\ldots$ & --- \\
\hline 0 & 103 & 13 & 1.1 & .4 & $\ldots$ & -.. \\
\hline 0 & 90 & 18 & 1.4 & .2 & --- & ... \\
\hline 0 & 84 & 19 & 1.5 & .0 & $\ldots$ &.-- \\
\hline 0 & 5.8 & 12 & 1.3 & .3 & $-\ldots$ & -- \\
\hline 0 & 2.4 & 14 & 1.1 & .0 & $\cdots$ & $\cdots$ \\
\hline 0 & 1.0 & 13 & 1.3 & .0 & $\ldots$ & $\ldots$ \\
\hline 0 & 29 & 8.8 & 1.4 & .2 & .... & - \\
\hline 3 & 29 & 9.2 & 1.4 & .1 & -- & -... \\
\hline 0 & 25 & 10 & 1.4 & .0 & .... & --. \\
\hline 2 & 29 & 9.0 & 1.4 & .1 & $-\cdots$ & $\ldots$ \\
\hline 0 & 32 & 13 & $\begin{array}{l}.4 \\
.7\end{array}$ & .0 & & $\ldots$ \\
\hline 0 & 34 & 13 & .5 & .3 & --- & $\ldots$ \\
\hline 0 & 32 & 11 & .8 & .0 & .... & $-\ldots$ \\
\hline 0 & 32 & 13 & 1.6 & .1 & $\ldots$ & --- \\
\hline$\ldots$ & 11 & 11 & $\ldots$ & - & & \\
\hline 0 & 14 & 12 & .5 & 5.0 & $\ldots$ & - \\
\hline 0 & 16 & 13 & .5 & 5.3 & $\ldots$ & - \\
\hline 0 & 17 & 13 & .4 & 6.1 & - & .... \\
\hline 0 & 16 & 12 & .4 & 6.1 & $\ldots$ & ... \\
\hline -... & $\ldots$ & 14 & .9 & ... & & \\
\hline .... & 61.7 & 11 & .6 & .00 & - & \\
\hline$\cdots$ & 59.7 & 12 & .9 & .0 &.-- & ... \\
\hline -..- & 69 & 11.9 & 1.0 & .01 & $\ldots$ & --. \\
\hline -... & 17.7 & 20.1 & .7 & .00 & ...- & -.. \\
\hline$\ldots$ & 13.2 & 18.5 & 1.6 & .0 & $\ldots$ & -- \\
\hline 7 & 15 & $20^{\circ}$ & $\begin{array}{l}1.8 \\
1.8\end{array}$ & .0 & 0.12 & - \\
\hline$\therefore$ & 16 & 17.7 & 1.7 & .03 & $\ldots$ & $\ldots$ \\
\hline$\ldots$ & 25.1 & 19.5 & 1.6 & .0 & --- & \\
\hline ..... & 19.5 & 15.8 & 1.8 & .05 & .... & -..- \\
\hline 0 & 14 & 12 & .4 & $-\ldots$ & -.. & $\ldots$ \\
\hline 0 & 12 & 8 & .4 & -.... & .... & -... \\
\hline$\ldots$ & 2.0 & 17 & 1.2 & .05 & .08 & -... \\
\hline 0 & .0 & 14 & 1.3 & $\ldots$ & & \\
\hline .... & $18^{\circ}$ & 7.8 & 6 & 6.3 & $\ldots$ & 0.02 \\
\hline --..- & 32 & $45^{\circ}$ & .4 & 57 &.- & .01 \\
\hline 0 & 11 & 5.0 & .7 & .0 & .00 & \\
\hline & 8.0 & 1.8 & .46 & .0 & .03 & 。 \\
\hline & 6.4 & 2.2 & .46 & .01 & .07 & \\
\hline
\end{tabular}

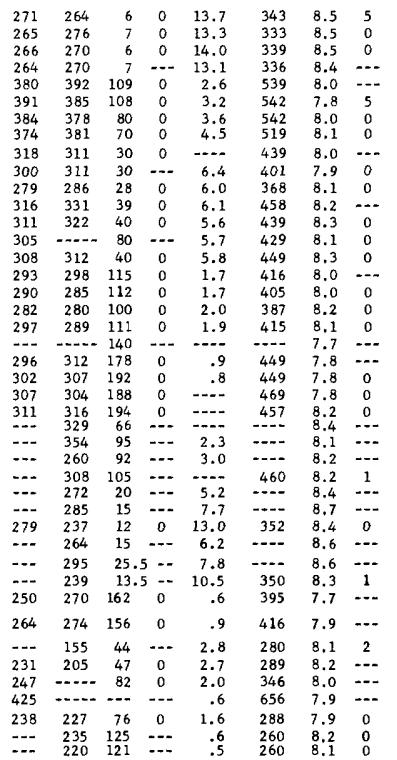

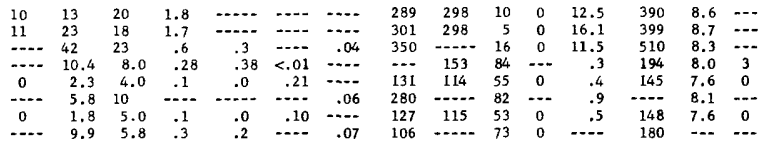

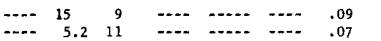

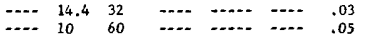

Unat111a Ordnanca Depot. We11 7.

Umatilla Ordnance Depot. Well 3

Umat11la Ordnance Depot. We11 5.

Unat11la Ordnance Depot. Well 4

Umat111a Ordnance Depot. Well 2. Umat11la County.

WSP-1620.

Unat11la Ordnance Depot. Well 1.

Ana1, Oregon Board of Health.

Do.

Do. Hermiston Wall 1.

ermiston well 3.

Ans1.Oreg. Bd. Health. Hermiston Well 3 . Do.

Do. 387 .

Do.

H1nkle Sta,we11.Anal, Oreg.Bd.Health.

WSP-1620.

Do.

Ana1. Oreg. Bd. Health. Well 1 ;

City well 1.

We11 3 in WSP-1620. C1ty Wel1 2.

Ana1.Oreg. Bd. Health. Well 6 .

Wash. WSB-21. Well 5 .

WIT B-237, no. 85. We11 3.

Wash. WSB-21. We11 1 .

$\begin{array}{rrrrrrrrrr}217 & \ldots \ldots & 105 & \ldots- & .7 & \ldots .- & 7.0 & \ldots & \text { WIT B-237, no. } 125 \text {. We11 } 2 .\end{array}$

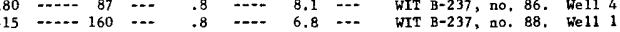

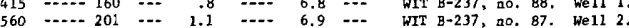

Columbia River Group, Washington, Oregon, and Idaho - Continued 


\begin{tabular}{|c|c|c|c|c|c|c|c|c|c|c|c|c|c|c|c|}
\hline \multirow[b]{2}{*}{ 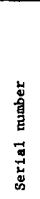 } & \multirow[b]{2}{*}{$\begin{array}{l}\text { Location } \\
\text { number } \\
\text { (s at end of } \\
\text { number } \\
\text { Indicates } \\
\text { gpring) }\end{array}$} & \multirow[b]{2}{*}{$\begin{array}{l}\text { Owner of well } \\
\text { or spring } \\
\text { (at time of } \\
\text { satipling) }\end{array}$} & \multirow[b]{2}{*}{$\begin{array}{l}\text { Depth } \\
\text { of } \\
\text { well } \\
\text { (feet) }\end{array}$} & \multirow[b]{2}{*}{$\begin{array}{l}\text { Depth of } \\
\text { water- } \\
\text { bearing } \\
\text { zona (s) } \\
\text { (feat) }\end{array}$} & \multirow[b]{2}{*}{$\begin{array}{l}\text { Date } \\
\text { water } \\
\text { sample } \\
\text { collected }\end{array}$} & \multirow[b]{2}{*}{ 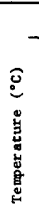 } & \multicolumn{9}{|c|}{ Milligrams per liter } \\
\hline & & & & & & & 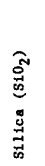 & $\begin{array}{l}\widehat{Q} \\
\mathbb{E} \\
\tilde{g}\end{array}$ & 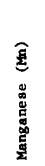 & $\begin{array}{l}\bar{\Xi} \\
\text { 罡 } \\
\text { 戛 }\end{array}$ & 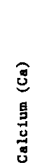 & 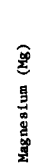 & 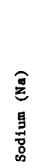 & 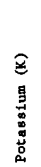 & 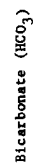 \\
\hline
\end{tabular}

JREGON--Con

\begin{tabular}{|c|c|c|c|}
\hline $432-\ldots-$ & $1 / 1-3 \mathrm{E} 3--$ & Oregon Pub.Co. & 930 \\
\hline 433--.- & $1 / 1-32 \times 1--$ & Alta Park-...- & 1100 \\
\hline $\begin{array}{l}434 \ldots \ldots \\
435-\ldots .\end{array}$ & $\begin{array}{l}1 / 4-10 D 1=- \\
1 / 24-6 \mathrm{Bl}=-\end{array}$ & YMCA & $\begin{array}{l}310 \\
100\end{array}$ \\
\hline $\begin{array}{l}436--\cdot- \\
437--.- \\
438---.\end{array}$ & $\begin{array}{l}1 / 25-23 \mathrm{~L} 1= \\
1 / 26-1 \mathrm{~J} 1=- \\
1 / 26-1 \mathrm{~J} 1=\end{array}$ & $\begin{array}{l}\text { Lexington- } \\
\text { 0. W. Cutsforth }\end{array}$ & $\begin{array}{r}420 \\
70 \\
-\end{array}$ \\
\hline $\begin{array}{l}438-\ldots- \\
439-\ldots .\end{array}$ & $1 / 32-9 L 1=$ & W. Chapman $=. . .$. & 491 \\
\hline $440-\cdots$ & $1 / 32-9 M 1-=$ & U.S. Gypsum Corp. & .735 \\
\hline $441----$ & $1 / 32-23 \mathrm{~J} 1-$ & Hilmer Horn-... & 794 \\
\hline $442 \ldots$ & 1/38-24R1- & H. L. Wagner--- & 1150 \\
\hline & $1 / 38-24 R 1=$ & -.... do $=-1-1$ & \\
\hline
\end{tabular}

$444-\ldots$ 1/1W-17A2- St. Mary' s Acad. 1507 445--.- 1/1W-26El- Savyers, Inc.-- 162 446-.-- 1/1W-27Cl- Robert Murphy-- 314

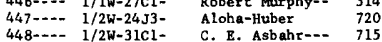

\section{T. 2 S., Ranges East}

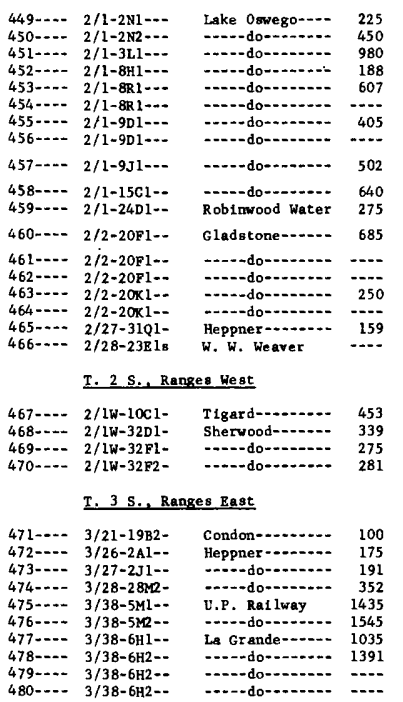

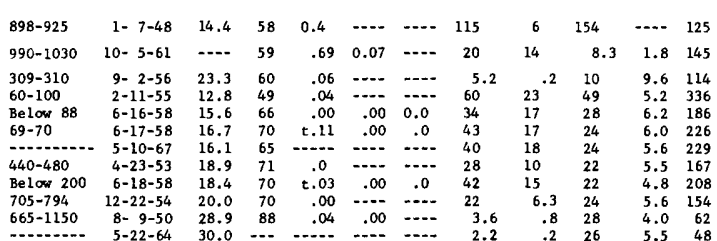

$\begin{array}{lrlllllllllr}1270-1505 & 11-19-53 & 22.8 & 45 & .33 & \ldots-.- & -\ldots & 222 & 45 & 290 & 40 & 63\end{array}$

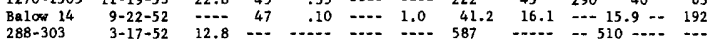

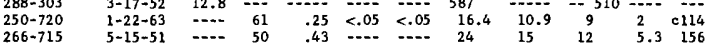

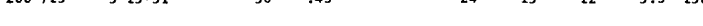

\begin{tabular}{|c|c|c|c|c|c|c|c|c|c|c|}
\hline--- & $11-4-53$ &.-- & 40 & .9 & $-\cdot-$ & $-\cdot-$ & 30 & 11.2 & $=--10.1=$ & c182 \\
\hline & $11-4-53$ & $\ldots$ & 40 & .3 & .0 & & 30 & 3.8 & $=10.8=$ & c 178 \\
\hline $957-980$ & - do do... & $\cdots$ & 30 & .1 & .0 & $\cdots$ & 10 & 2.2 & $=16.0=$ & c 137 \\
\hline $166-188$ & $\cdots$ do $-\cdot$ & $\cdots$ & 30 & .1 & .0 & $\cdots$ & & 14 & $8.2=$ & 120 \\
\hline ........... & $8-21-44$ & $\cdots$ & 53 & 1.2 & .1 & $--\cdot$ & 8.9 & 3.6 & $\ldots 26.1$ & $\cdots$ \\
\hline n. & $11-6=45$ & $-\cdots$ & 55 & t. 52 & .12 & -- & 92 & 30 & $76 \ldots$ & 168 \\
\hline $190-405$ & $5-14-46$ & $\cdots$ & 49 & t. 5 & $\cdots$ & & 21 & 7.5 & 17 -.-- & 132 \\
\hline & $2-10-61$ & $\cdots$ & $\cdots$ & .13 & $<.05$ & .02 & 27.7 & 26.2 & 3.3 & c167 \\
\hline$\left[\begin{array}{l}140-160 \\
280-340\end{array}\right]$ & $11-4-53$ & $\ldots$ & $\cdots$ & t.1 & .0 & $\cdots$ & 17 & 6 & $-{ }^{--} 6.1=$ & 85 \\
\hline $260-600$ & --don- & -- & 40 & .1 & .0 & & 22 & 10 & 8.8 & c 137 \\
\hline & $\cdots$ do $=$ & 5.6 & 40 & .4 & .0 & & 34 & 9.8 & $11.1 \ldots$ & c163 \\
\hline$\left[\begin{array}{l}200-210 \\
675-685\end{array}\right.$ & $2-28-56$ & 16.6 & 53 & $\ldots$ & $\cdots$ & $\cdots$ & 42 & $-n+\cdots$ & $\cdots$ & 116 \\
\hline- & $7-26-50$ & $\cdots$ & 53 & .07 & .05 & & 35. & 6.2 & $\cdots 87.1=$ & 122.2 \\
\hline & & & 49 & $\cdots$ & $\cdots$ & & & 12 & & 114 \\
\hline$\cdots$ & $3-17-52$ & $\ldots$ & 24 & .1 & 0 & & & 5.3 & $\ldots 82.3=$ & 116 \\
\hline & $6-9-53$ & & 49 & .43 & .05 & & 54.3 & 14.7 & $95.5 \cdots$ & 116 \\
\hline 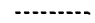 & $4-1-54$ & 12. & 53 & .01 & $\ldots$ & & 18 & 8,8 & 1.4 & 105 \\
\hline-- & ---do-..- & & 55 & .02 & $\ldots$ & & 26 & 5.8 & 3.9 & 144 \\
\hline
\end{tabular}

$\begin{array}{rrrrrrrrrrrr}192-453 & 4-21-58 & 12.2 & 72 & t .03 & .00 & .0 & 21 & 8.8 & 8.5 & 2.8 & 124 \\ 137-339 & 12-20-46 & \ldots . . & 26 & .1 & \ldots . . & -\ldots .- & 8.9 & 2.6 & \ldots-.20 .5 & -. & 92\end{array}$

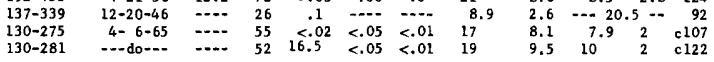

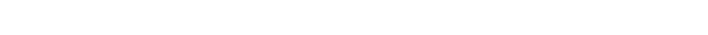

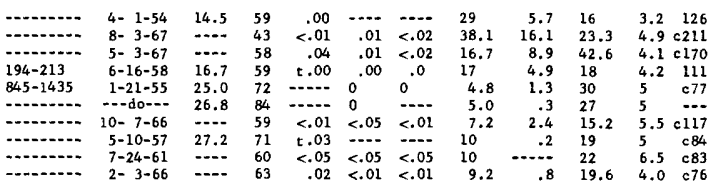

TABLE 1. - Chemical analyses of ground water in the basalt of the 


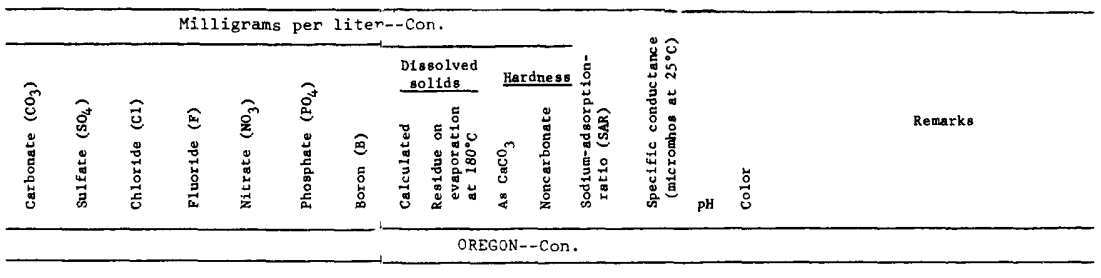

\begin{tabular}{|c|c|c|c|c|c|c|c|c|c|c|c|c|c|c|}
\hline 12 & 7.1 & 356 & $\ldots$ & $\ldots$ & $-\ldots$ & $\ldots$ & -.. & 918 & 312 & $\cdots$ & 3.3 & .... & 8.2 & $\cdots$ \\
\hline ..... & .8 & 3.5 & 0.2 & 0.2 & 0.95 & -..- & 180 & 174 & 106 & 0 & .4 & 236 & 7,2 & $\cdots$ \\
\hline 5 & 1.2 & 92 & 3.2 & .5 & .... & 0.38 & $\ldots$ & 326 & 14 & 0 & 1.2 & 517 & 8.6 & \\
\hline 0 & $40^{\circ}$ & 27 & .3 & 2.9 & .... & -... & 422 & 425 & 244 & 0 & 1.4 & 662 & 7.0 & $\ldots$ \\
\hline 0 & 4.3 & 48 & .4 & .0 & .00 & $\ldots$ & 295 & 290 & 155 & 2 & 1.0 & 447 & 7.7 & 0 \\
\hline 0 & 19 & 20 & .4 & .0 & .00 &.-- & 310 & 308 & 177 & 0 & .8 & 442 & 7.8 & 0 \\
\hline$\ldots$ & 15 & 22 & 5 & $\ldots$ & $\therefore$ & $\ldots$ & 303 & . & 174 & $\ldots$ & 8 & 437 & 7.9 & ... \\
\hline -... & 13 & 8.5 & .5 & 1.8 & .... & .01 & 243 & $\ldots$ & 111 & 0 & .9 & 310 & 7.8 & $\cdots$ \\
\hline 0 & 22 & 14 & .4 & 4.1 & .00 & $\ldots$ & 296 & 266 & 166 & 0 & .8 & 418 & 7.7 & 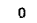 \\
\hline$\cdots$ & 7.9 & 5.0 & .5 & .3 & $\ldots$ & .02 & 218 & 223 & 81 & 0 & 1.2 & 263 & 7.9 & 0 \\
\hline 4.9 & 8.3 & 3.1 & 2.0 & .2 & .... & .10 & 174 & $\cdots$ & 12 & $\ldots$ & 3.5 & 148 & 8.0 & - \\
\hline 12 & 5.3 & 2.5 & $\ldots$ & 0 & $\ldots$ & .07 & $\ldots$ & $\ldots$ & & 5 -- & 1,4 & 143 & 8.8 & \\
\hline
\end{tabular}

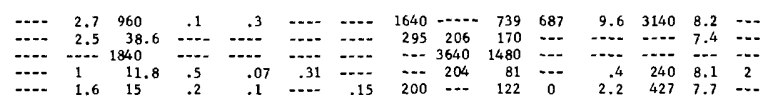

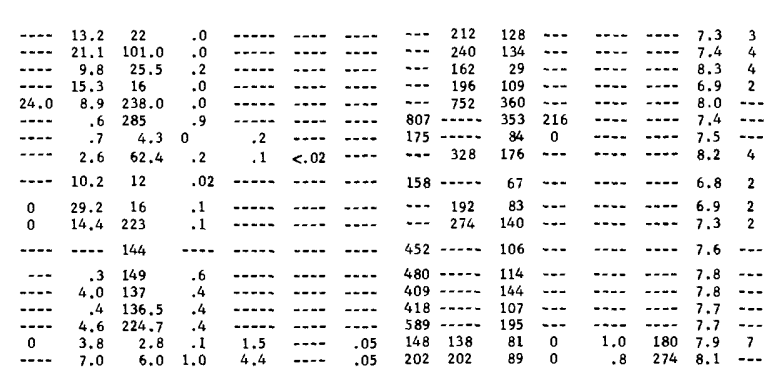

Ana1. Charlton Lab. Multnomsh Co. WSP-1619-0.

WSP- 1793 .

Morrow County.

HA-387.

WSP-1620, Umat111a County. Do.

WSP-1597. Union County.

Analyot unknown.

WSP-1697. Washingt on County. Do. Ana1. Charlton Laboratories. Ana1. Oregon Board of Health

Anal. Oregon Board of Health. clackamas county.

$$
\text { Do. }
$$

Do.

WSP-1697. Ans 1. Oreg. Bd. Heal th. Anal, Oreg. Bd.Health. Well 3 . WSP-1697. Ana1. Char 1 ton Labs

Ana1. Oregon Board of Health

wSP-1697. Oreg. Bd. Health.

Anal. Oregon Board of Health.

Do.

Do.
Do.
WSP-1793. We11 2.
Do.

Do.

Morrow County.
Flow estimated $35 \mathrm{gpm}$

T1gard well 2. Washington County.

We11 1. Ans1. Oreg. Board Health.
Well 2.Anal. Oreg. Board Health.

G111lam County.

Sheep corral well.0reg.Bd. Herlth. Well 4.Oreg. Bd. Health. Morrow Co. Well 1 .

WSP-1597.0reg. Bd. Health. Union Co. Do.

We11 1.Ana 1. Oreg.Bd.Health.

Hell 2.Anal. Oreg. Bd. Healt' Do.

Columbia River Group, Washington, Oregon, and Idaho — Continued 


\begin{tabular}{|c|c|c|c|c|c|c|c|c|c|c|c|c|c|c|c|}
\hline \multirow[b]{2}{*}{ 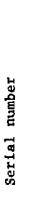 } & \multirow[b]{2}{*}{$\begin{array}{l}\text { Location } \\
\text { number } \\
\text { (s at end of } \\
\text { number } \\
\text { Indicates } \\
\text { spring) }\end{array}$} & \multirow[b]{2}{*}{$\begin{array}{l}\text { Owner of well } \\
\text { or spring } \\
\text { (at time of } \\
\text { samp I Lng) }\end{array}$} & \multirow[b]{2}{*}{$\begin{array}{l}\text { Depth } \\
\text { of } \\
\text { vel1 } \\
\text { (feet) }\end{array}$} & \multirow[b]{2}{*}{$\begin{array}{l}\text { Depth of } \\
\text { water- } \\
\text { bear Ing } \\
\text { zone (s) } \\
\text { (feet) }\end{array}$} & \multirow[b]{2}{*}{$\begin{array}{l}\text { Date } \\
\text { water } \\
\text { Bauple } \\
\text { collected }\end{array}$} & \multirow[b]{2}{*}{ 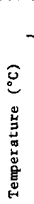 } & \multicolumn{9}{|c|}{ Milligrams per liter } \\
\hline & & & & & & & 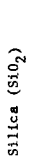 & 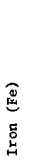 & 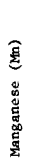 & 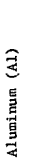 & 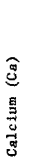 & 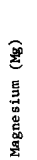 & 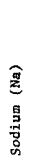 & 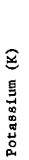 & 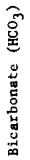 \\
\hline
\end{tabular}

OREGON--CON.

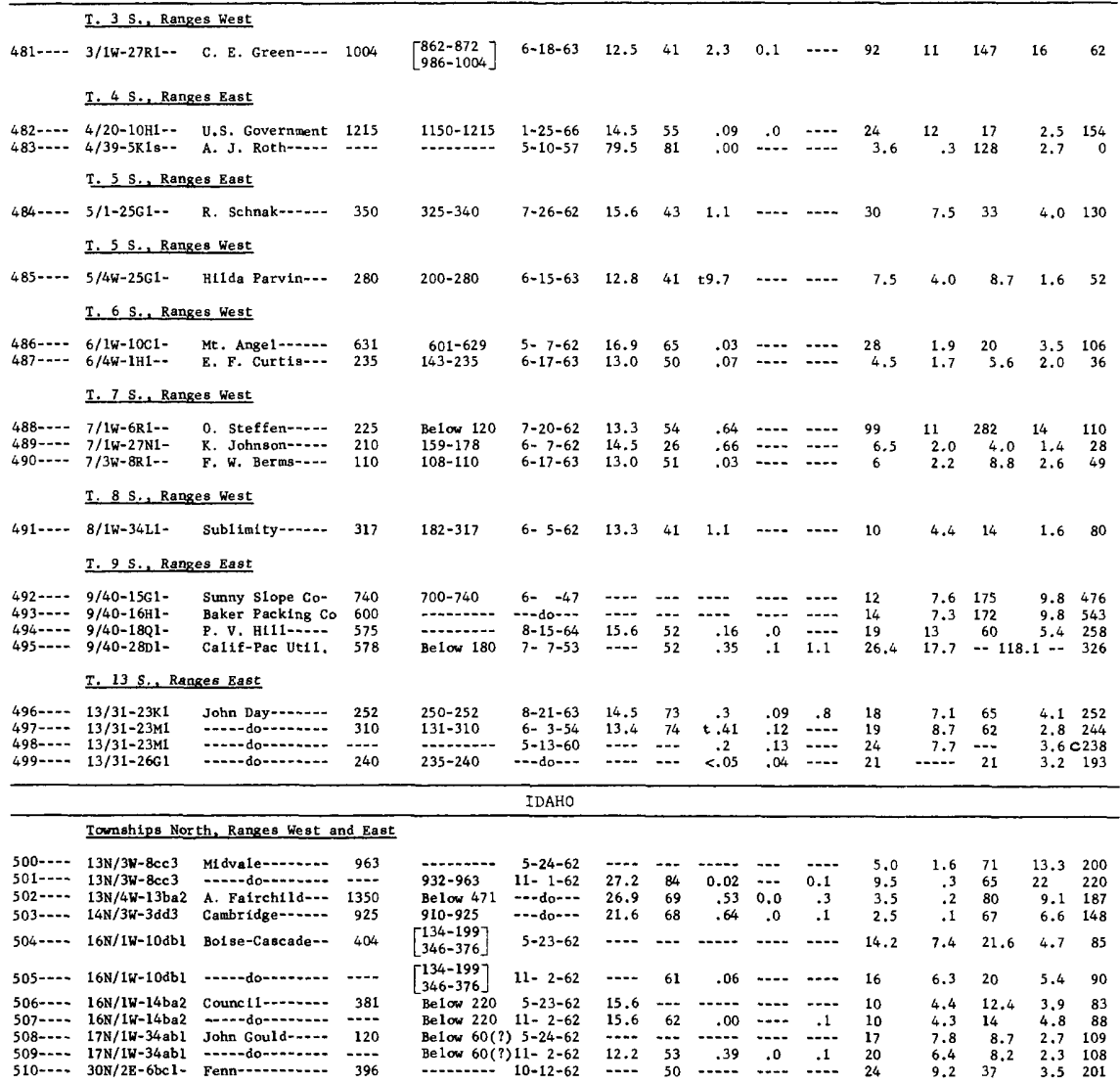

TABLE 1. - Chemical analyses of ground water in the basalt of the 


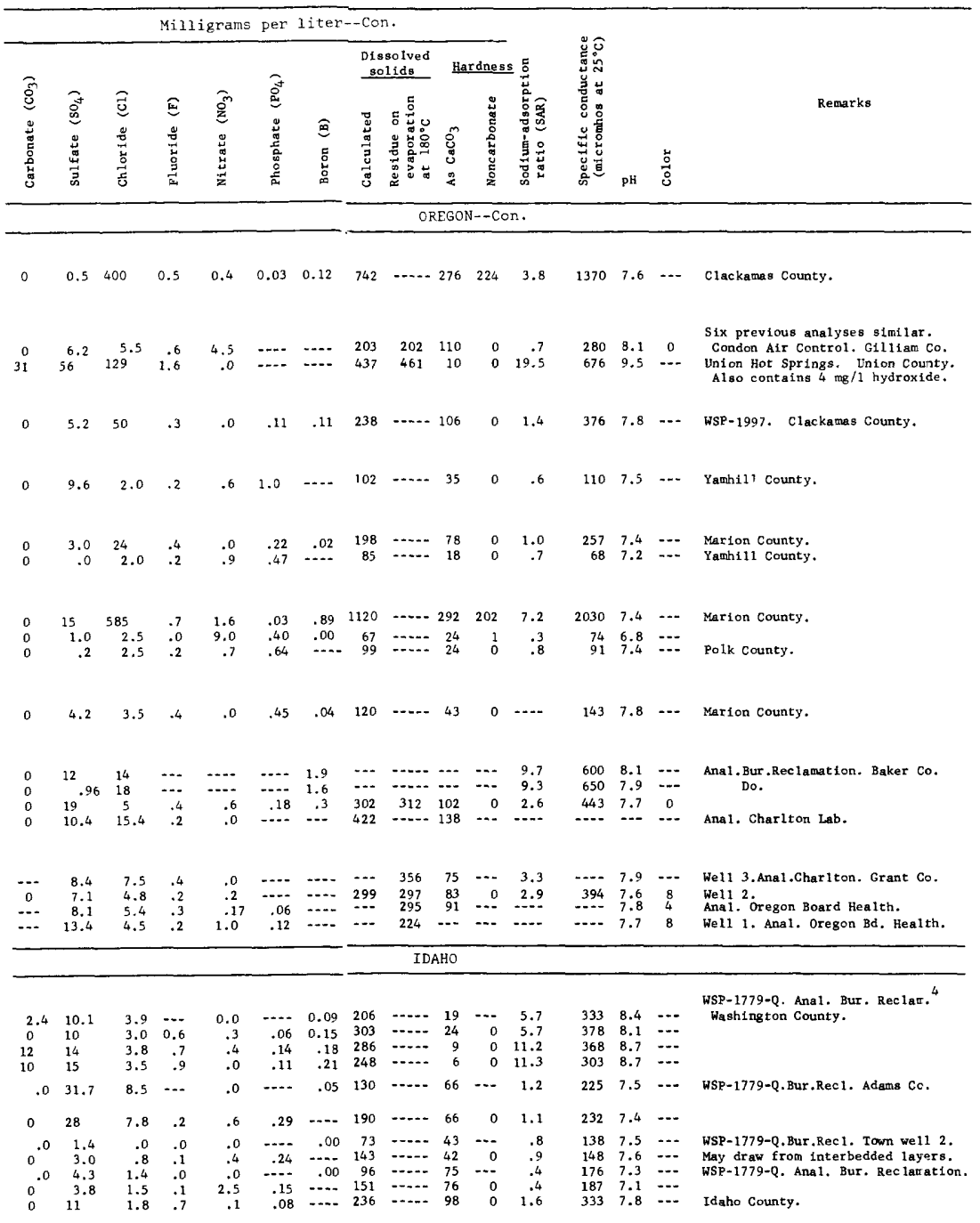

Columbia River Group, Washington, Oregon, and Idaho - Continued 


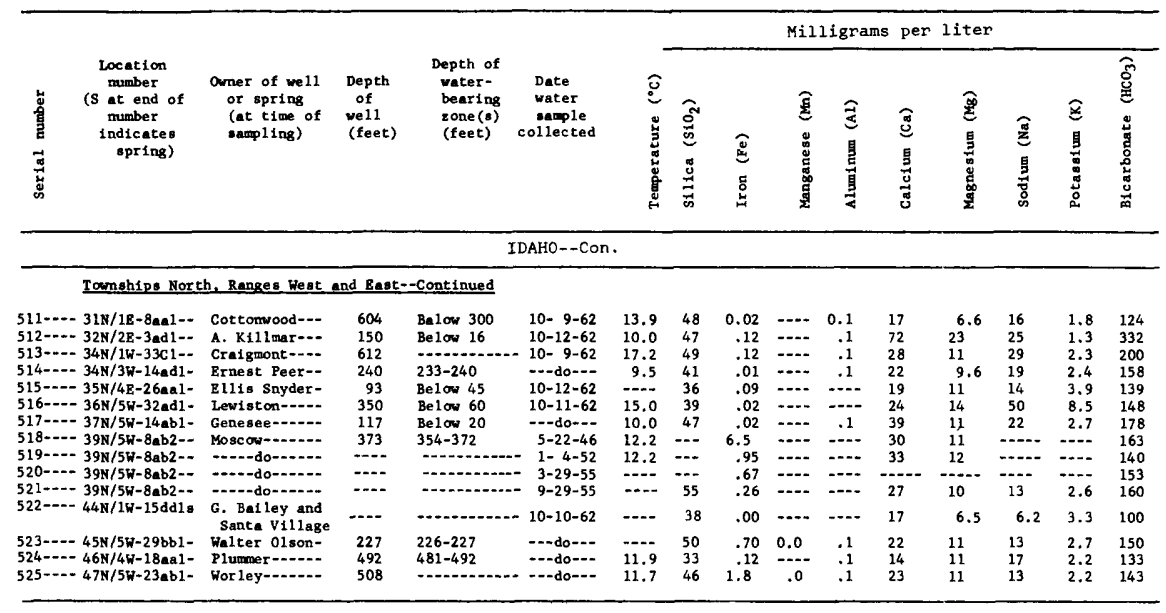

1 County locetion reference applies continuous ly downord unt11 a new county reference is given.

2 Wash. WSB-24 means Water Supp1y Bulletin 24 of the Washington Department of Water Resources. See references cited.

3 Wesh. I. T., B-237, or WIT B-237, weans Bulletin 237 of the WashIngton Institute of Technology. See references c1ted.

4 wSP-1779-Q means Water-Supply Paper 1779-Q of the U.S. Geological Survey. See references cited.

$t$ Total 1ron.

c Calculated. In the bicarbonete column this indlcates value celculated from the bicerbonete alkallnity reported on the analysis.

a Temperature of $105^{\circ} \mathrm{C}$ used for residue meesurement on all enalyses of Oregon Boerd of Heelth.

TABLE 1. - Chemical analyses of ground water in the basalt of the 


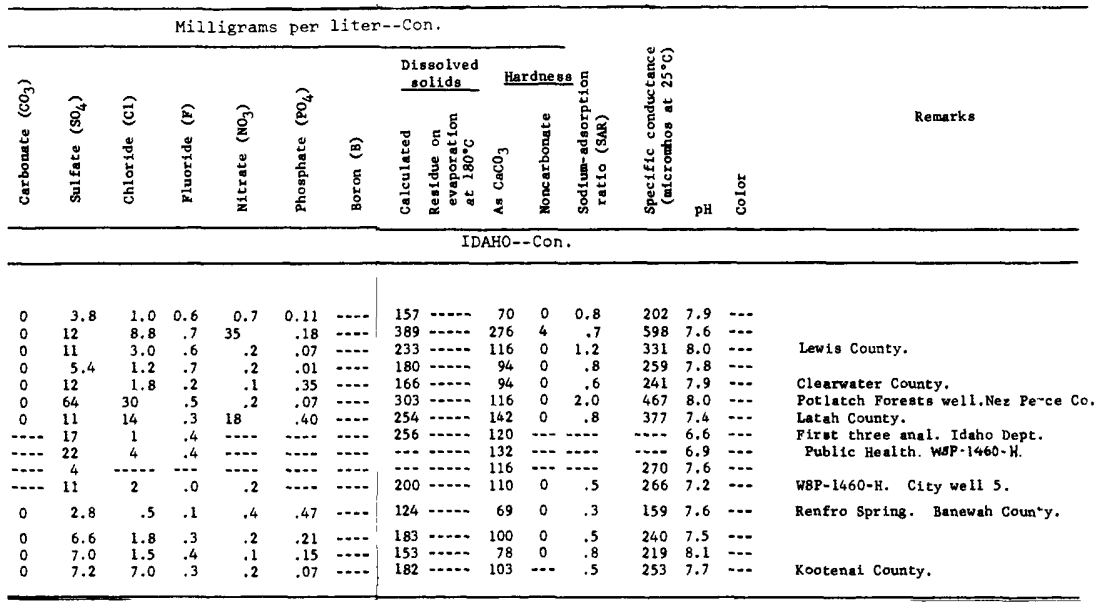

Columbia River Group, Washington, Oregon, and Idaho - Continued 


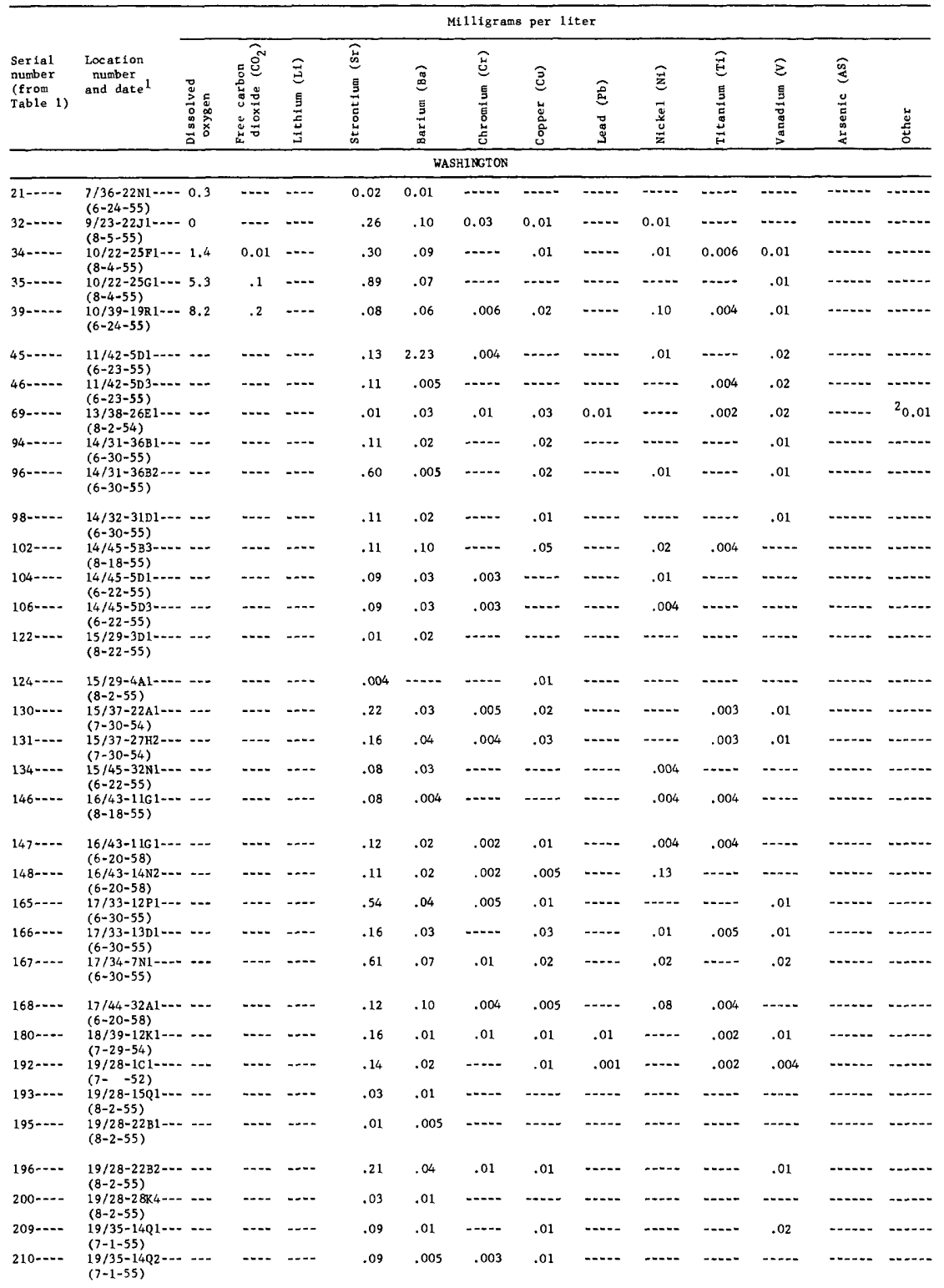

TABLE 2. - Minor elements in the chemical analyses of ground water in the basalt of the Columbia River Group, Washington and Oregon 


\begin{tabular}{|c|c|c|c|c|c|c|c|c|c|c|c|c|c|c|}
\hline \multirow[b]{2}{*}{$\begin{array}{l}\text { Serial } \\
\text { number } \\
\text { (from } \\
\text { Table } 1\end{array}$} & \multirow[b]{2}{*}{$\begin{array}{l}\text { Location } \\
\text { number } \\
\text { and date } 1\end{array}$} & \multicolumn{12}{|c|}{ Milligrams per liter } & \multirow[b]{2}{*}{ 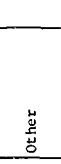 } \\
\hline & & 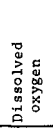 & 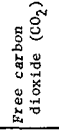 & 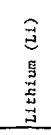 & 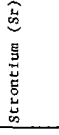 & 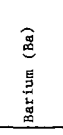 & 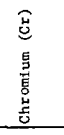 & $\begin{array}{l}3 \\
0 \\
0 \\
\dot{0} \\
0 \\
0 \\
0\end{array}$ & 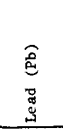 & 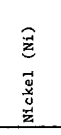 & 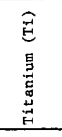 & 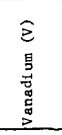 & 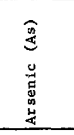 & \\
\hline \multicolumn{15}{|c|}{ WASHINGTON--Cont Inued } \\
\hline $211-\cdots$ & $\begin{array}{l}19 / 35-23 \mathrm{Cl}-- \\
(7-1-55)\end{array}$ & $\cdots$ & $--\cdot$ & -... & 0.37 & 0.04 & $-\cdots$ & 0.01 & $\cdots+-$ & $-\cdots$ & $\cdots$ & 0.01 & ---- & $\cdots$ \\
\hline $213---$ & $\begin{array}{l}19 / 35-23 k 1-- \\
(7-1-35)\end{array}$ & -- & $\cdots$ & $\cdots$ & .12 & .01 & 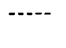 & .02 & $\cdots$ & $-\cdots$ & $\cdots$ & 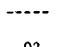 & ........ & $\cdots$ \\
\hline $216=-2$ & $\begin{array}{l}20 / 24-7 R 1=- \\
(8-3-55)\end{array}$ & +- & $\cdots$ & 0. & .17 & .01 & $\cdots$ & $-\cdots$ & ---- & $-\cdots$ & $\ldots$ & .02 & 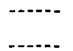 & \\
\hline $246=-1$ & $\begin{array}{l}21 / 26-8 M 1-- \\
(7-22-55)\end{array}$ & $\cdots$ & $\cdots$ & $\begin{array}{r}0.08 \\
.02\end{array}$ & --- & $\ldots$ & $\ldots$ & $-\cdots$ & $-\cdots$ & $-\cdots$ & -.--- & $\begin{array}{l}.01 \\
.005\end{array}$ & - & \\
\hline $247=-=$ & $\begin{array}{l}21 / 26-8 \mathrm{~N} 1-- \\
(7-22-55)\end{array}$ & $\cdots$ & $\cdots$ & .02 & $\cdots$ & $\cdots$ & $\cdots$ & $\cdots$ & $\cdots-$ & 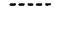 & 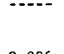 & .005 & - & \\
\hline $248-\cdots$ & $\begin{array}{l}21 / 26-14 \mathrm{~L} 1-- \\
(7-22-55)\end{array}$ & -- & 0.09 & 1.77 & 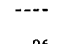 & --- & $\cdots$ & $\cdots$ & ---- & $-\cdots$ & 0.006 & --- & $\cdots--$ & \\
\hline $250----$ & $\begin{array}{l}21 / 26-16 \mathrm{~B} 3-- \\
(7-22-55)\end{array}$ & --- & --- & --- & .06 & --- & $-\cdots$ & .007 & $-\cdots$ & 0.01 & $-\cdots$ & .01 & -...- & -- \\
\hline 253---- & $\begin{array}{l}21 / 26-21 \mathrm{E} 1-- \\
(7-22-55)\end{array}$ & --- & ---- & --- & .08 & .004 & -...- & - & -..-- & .005 & - - - & .01 & - - & ---- \\
\hline 258---- & $\begin{array}{l}21 / 38-23 \mathrm{~A} 2-- \\
(7-1-55)\end{array}$ & $\cdots$ & $\cdots$ & $-\cdot-$ & .10 & .02 & .004 & .004 & $-\cdots$ & -...- & .004 & .01 & -.... & $\ldots$ \\
\hline $263=\ldots$ & $\begin{array}{l}22 / 26-24 L 1=- \\
(7-22-55)\end{array}$ & -- & +- & --- & .10 & .07 & ----- & --- & --- & $-\cdots$ & $\cdots$ & $\cdots$ & $-\cdots$ & - \\
\hline $264----$ & $\begin{array}{l}22 / 27-19 \mathrm{~N} 1-- \\
(7-22-55)\end{array}$ & --- & $\cdots$ & -- & .12 & .005 & ---- & .005 & 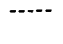 & $\cdots$ & ---- & .01 & $-\cdots-$ & \\
\hline $270----$ & $\begin{array}{l}23 / 29-14 \mathrm{~J} 1-- \\
(8-10-54)\end{array}$ & $-\cdot$ & $\cdots--$ & --- & .09 & .03 & -.--- & .005 & $\cdots$ & - & $\cdots$ & .02 & $\cdots$ & - \\
\hline $271---$ & $\begin{array}{l}(23 / 29-23 \mathrm{G} 1- \\
(8-10-54)\end{array}$ & --- & $\cdots$ &.-- & .06 & .04 & .003 & .005 & $-\cdots$ & ---- & $\cdots$ & $\cdots-$ & $\cdots-\cdots$ & \\
\hline \multicolumn{15}{|c|}{ OREGON } \\
\hline $300----$ & $\begin{array}{l}1 \mathrm{~N} / 1-34 \mathrm{~N} 4--- \\
(1-9-47)\end{array}$ & -- & 3.0 & $\cdots$ & -- & --- & $---\cdot$ & $\cdots$ & $\cdots$ & $\cdots$ & $-\cdots$ & $\cdots$ & n- & -...- \\
\hline $302-\cdots$ & $\begin{array}{l}1 \mathrm{~N} / 1-34 \mathrm{P} 2--- \\
(4-3-51)\end{array}$ & $\cdots$ & 3.0 & $\cdots$ & 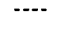 & --- & $\cdots$ & $\cdots$ & $\cdots$ & $\cdots$ & $\cdots$ & --- & $\cdots-$ & $\cdots$ \\
\hline $308---$ & $\begin{array}{l}1 N / 13-4 \mathrm{P} 1-\cdot- \\
(6-25-54)\end{array}$ & -- & 8.4 & --- & $-\cdots$ & --- & ---- & ---- & --- & ---- & -..-- & $\cdots$ & $\cdots$ & $\cdots-$ \\
\hline $324-\cdots$ & $\begin{array}{l}1 \mathrm{~N} / 39-22 \mathrm{~B} 1-- \\
(3-17-67)\end{array}$ & $\cdots$ & .5 & $-\cdots$ & $m$ & $\cdots$ & ----- & $+\cdots$ & --- & $\cdots$ & $-\cdots$ & $\cdots$ & 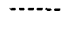 & $\cdots$ \\
\hline $326----$ & $\begin{array}{l}1 \mathrm{~N} / 2 \mathrm{~W}-24 \mathrm{~J} 1 \mathrm{-} \\
(10-24-62)\end{array}$ & -- & -..- & --- & -- & -..- & $\cdots$ & $-\ldots$ & 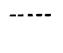 & $\cdots-$ & $-\cdots$ & $-\cdots$ & 0.0 & ${ }^{4} 17.2$ \\
\hline $328-\ldots-$ & $\begin{array}{l}1 \mathrm{~N} / 3 \mathrm{~W}-1 \mathrm{~K} 2--- \\
(12-4-67)\end{array}$ & -- & 2.2 & $\cdots$ & $\cdots$ & $\cdots$ & 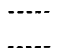 & 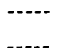 & -..- & 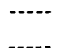 & -...- & $\cdots$ & $<.005$ & -...- \\
\hline $334-\cdots$ & $\begin{array}{l}2 N / 13-32 J 3-- \\
(1-10-62)\end{array}$ & -- & 2.4 & $-\cdots$ & --- & $\cdots$ & $-\cdots$ & - & $-\cdots$ & 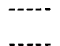 & ---- & $-\cdots$ & $<-005$ & $\ldots$ \\
\hline $349-\cdots$ & $\begin{array}{l}2 N / 32-10 \mathrm{~F} 1=- \\
(6 / 13-52)\end{array}$ & -- & .00 & $\cdots$ & $\cdots$ & $-\cdots$ & ---- & $-\cdots$ & $-\cdots$ & $-\cdots$ & $-\cdots$ & $-\cdots$ & $<.005$ & 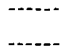 \\
\hline $350=-\ldots$ & $\begin{array}{l}2 N / 32-10 F 1=- \\
(7-15-54)\end{array}$ & -- & 9.0 & $\cdots$ & $-\cdots$ & --- & $---\cdot$ & -...- & $\cdots$ & $+\cdots$ & $-\cdots$ & - & - & - \\
\hline $352=--$ & $\begin{array}{l}2 N / 32-10 N 1=- \\
(7 / 15-54)\end{array}$ & -- & 4.0 & --- & --- & --- & ---- & $\cdots$ & $-\cdots$ & $-\cdots$ & $-\cdots$ & $\cdots$ & $-\cdots$ & $\cdots$ \\
\hline $355-\cdots$ & $\begin{array}{l}2 N / 33-14 G 1-- \\
(12-19-66)\end{array}$ & $-\cdot$ & 1.7 & $\cdots$ & $\cdots$ & -- & $\cdots$ & -...- & $-\cdots$ & $-\cdots$ & $\cdots$ & $-\cdots$ & ---- & $-\cdots-$ \\
\hline $358-\cdots$ & $\begin{array}{l}3 \mathrm{~N} / 21-2801- \\
(9-14-62)\end{array}$ & --- & .1 & -..- & --- & --- & ---- & ..... & ---- & +...- & $\cdots$ & $\cdots$ & ----- & -...- \\
\hline $367 \ldots$ & $\begin{array}{l}4 \mathrm{~N} / 24-22 \mathrm{G} 1- \\
(11-11-42)\end{array}$ & $\cdots$ & 5.5 & $\cdots$ & $\cdots$ & $\cdots$ & $\cdots$ & $-\cdots$ & ---- & $-\cdots$ & -.-- & $\cdots$ & $---\cdots$ & $\cdots$ \\
\hline $377-\cdots$ & $\begin{array}{l}4 \mathrm{~N} / 27-5 \mathrm{C} 1-- \\
(3-30-62)\end{array}$ & -- & .9 & $\cdots$ & ---- & $\cdots$ & --.- & $\cdots$ & $-\ldots$ & $\cdots$ & ---- & ---- & ---- & -..-- \\
\hline $404 \ldots$ & $\begin{array}{l}4 N / 28-10 P 1- \\
(6-29-64)\end{array}$ & $\cdots$ & 2.1 & $\cdots$ & $--\cdot$ & $\cdots$ & $\cdots$ & --- & $\cdots$ & $\ldots$ & --- & $\cdots$ & $<.005$ & -..-- \\
\hline 410---- & $\begin{array}{l}4 N / 28-11 N 1-- \\
(6-29-64)\end{array}$ & --- & 1.3 & $\cdots$ & $\cdots$ & $\cdots$ & $\cdots$ & $\ldots$ & $\ldots$ & $\ldots$ & $\cdots$ & $\cdots$ & $<.005$ & \\
\hline 413---- & $\begin{array}{l}4 / 28-27 J 11= \\
(2-13-63)\end{array}$ & --- & 1,5 & $\cdots$ & --- & --- & --- & $-\ldots$ & $-\cdots$ & ---- & ---- & $\cdots$ & .005 & - \\
\hline $417---$ & $\begin{array}{l}4 \mathrm{~N} / 35-19 \mathrm{~L} 2-- \\
(6-17-58)\end{array}$ & --- & --- & $\cdots$ & 0.2 & $-\infty$ & ---- & --- & $\cdots$ & $-\cdots$ & $-\cdots$ & +- & -...-- & -- \\
\hline $418-\cdots$ & $\begin{array}{l}4 / 35-22 Q 1-\cdots \\
(3-2-67)\end{array}$ & $\cdots$ & 1.7 & $\cdots$ & $\ldots$ & $\cdots$ & $\cdots$ & $-\cdots$ & ---- & $\ldots$ & $-\cdots$ & $\cdots$ & $<.005$ & -....- \\
\hline $419=--$ & $\begin{array}{l}4 N / 35-22 Q 2=- \\
(3-2-67)\end{array}$ & $-\cdot$ & 2.2 & $\cdots$ & --- & $\cdots$ & $\cdots$ & $\cdots$ & --- & --- & ---- & $\cdots$ & $<.005$ & -- \\
\hline
\end{tabular}

TABLE 2. - Minor elements in the chemical analyses of ground water in the basalt of the Columbia River Group, Washington and Oregon - Contirued 


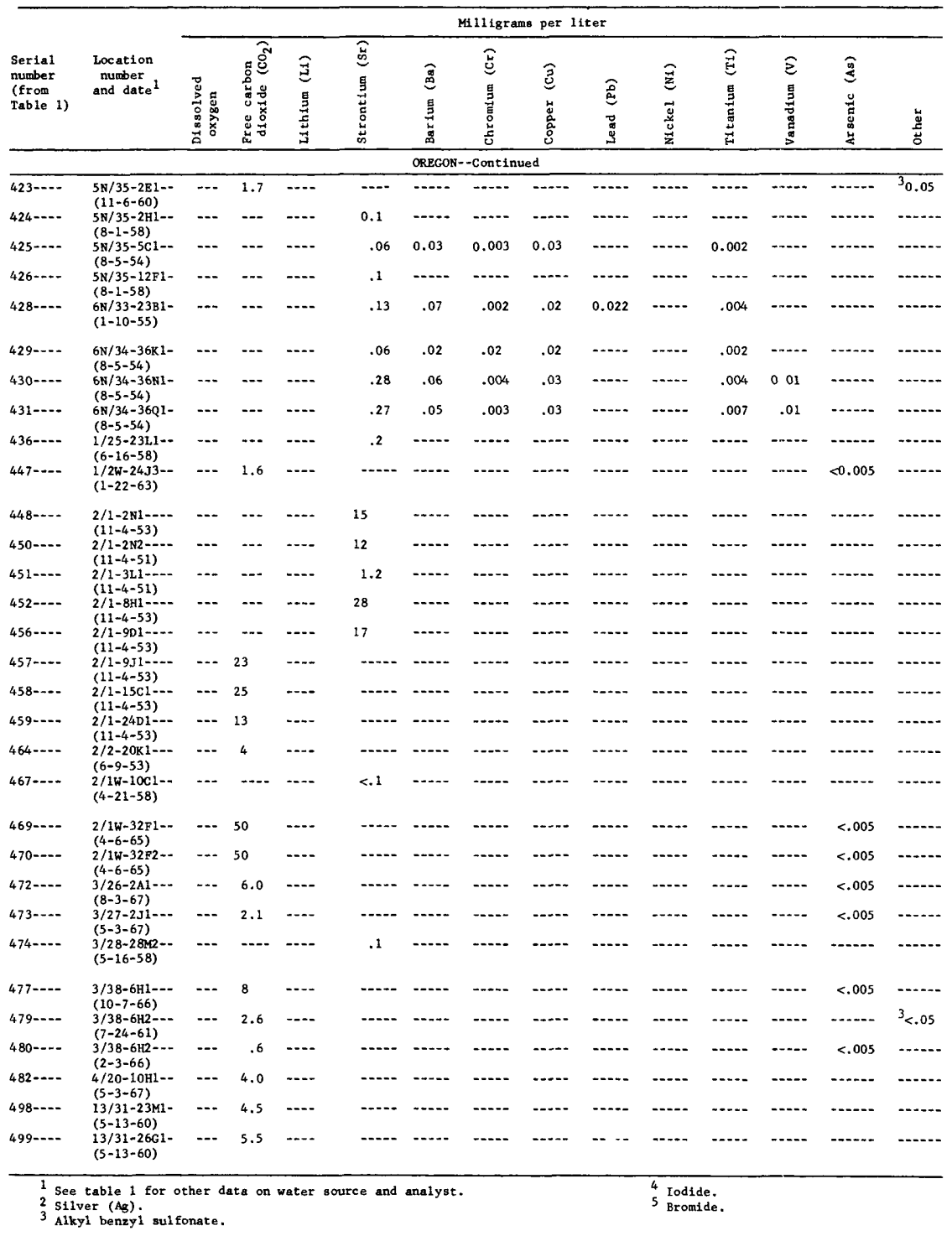

TABLE 2. - Minor elements in the chemical analyses of ground water in the basalt of the Columbia River Group, Washington and Oregon-Continued 


\begin{tabular}{lccccc}
\hline & & Beta-gama \\
Serial & Location & activity & Radium (Ra) & Uranium (U) \\
number & number & Date & (micro- & (microgr?ms \\
(from & of & sampled & $\begin{array}{c}\text { microcuries } \\
\text { per liter) }\end{array}$ & $\begin{array}{l}\text { microcuries } \\
\text { per liter) }\end{array}$ & per 1iter) \\
\hline
\end{tabular}

\begin{tabular}{|c|c|c|c|c|c|}
\hline \multicolumn{6}{|c|}{ WASHINGTON } \\
\hline $\begin{array}{l}9-\cdots-1 \\
38-\cdots-1-\end{array}$ & $\begin{array}{l}6 \mathrm{~N} / 35-10 \mathrm{P} 1 \\
10 / 28-17 \mathrm{~B} 1\end{array}$ & $\begin{array}{l}8-1-58 \\
6-15-51\end{array}$ & $\begin{array}{r}14.1 \\
----\end{array}$ & $\begin{array}{l}0.3 \\
<1\end{array}$ & $0.1 \pm 0.1$ \\
\hline $43-----$ & $11 / 27-20 \mathrm{Ml}$ & ---do--- & ------ & $<1$ & $----0-0$ \\
\hline $59-\ldots-$ & $13 / 24-25 \mathrm{E} 1$ & $12-1-51$ & $<100$ & $<1$ & --------- \\
\hline $61----$ & $13 / 24-36 \mathrm{D} 1$ & --- do --- & $<100$ & $<1$ & $<100$ \\
\hline 63------ & $13 / 25-30 G 1$ & $12-1-51$ & $<100$ & $<1$ & $<100$ \\
\hline 194----- & $19 / 28-15 Q 1$ & $11-29-55$ & $<14$ & $<.1$ & $<.1$ \\
\hline
\end{tabular}

\begin{tabular}{|c|c|c|c|c|c|}
\hline \multicolumn{6}{|c|}{ OREGON } \\
\hline 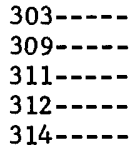 & $\begin{array}{l}1 \mathrm{~N} / 12-14 \mathrm{R} 1 \\
1 \mathrm{~N} / 13-4 \mathrm{P} 1 \\
1 \mathrm{~N} / 13-8 \mathrm{~L} 1 \\
1 \mathrm{~N} / 13-14 \mathrm{M} 1 \\
1 \mathrm{~N} / 13-32 \mathrm{G} 2\end{array}$ & $\begin{array}{r}7-31-58 \\
7-30-58 \\
7-31-58 \\
7-30-58 \\
--- \text { do--- }\end{array}$ & $\begin{array}{r}13 \\
<9 \\
<10 \\
<7 \\
8.6\end{array}$ & $\begin{array}{r}<0.1 \\
<.1 \\
<.1 \\
<.1 \\
.1\end{array}$ & $\begin{array}{r}<0.1 \\
<.1 \\
0.1 \pm 0.1 \\
.5 \pm \quad .1 \\
<.1\end{array}$ \\
\hline 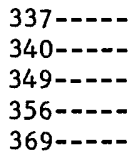 & $\begin{array}{l}2 N / 25-28 D 1 \\
2 N / 27-14 M 1 \\
2 N / 32-10 F 1 \\
2 N / 33-33 N 1 \\
4 N / 25-7 R 1\end{array}$ & $\begin{array}{l}6-16-58 \\
6-17-58 \\
6-13-52 \\
6-18-58 \\
6-17-58\end{array}$ & $\begin{array}{c}<13 \\
14 \\
<250 \\
8.3 \\
<19\end{array}$ & $\begin{array}{l}<.1 \\
<.1 \\
.14 \\
<.1 \\
<.1\end{array}$ & $\begin{array}{l}<.1 \\
.3 \pm \quad .1 \\
.1 \pm .4 \\
10 \pm 1.0\end{array}$ \\
\hline 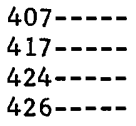 & $\begin{array}{l}4 \mathrm{~N} / 28-11 \mathrm{~N} 1 \\
4 \mathrm{~N} / 35-19 \mathrm{~L} 2 \\
5 \mathrm{~N} / 35-2 \mathrm{H} 1 \\
5 \mathrm{~N} / 35-12 \mathrm{~F} 1\end{array}$ & $\begin{array}{r}--- \text { do }--- \\
--- \text { du-n- } \\
8-1-58 \\
--- \text { do--- }\end{array}$ & $\begin{array}{l}14 \\
<8 \\
<5 \\
<5\end{array}$ & $\begin{array}{l}<.1 \\
<.1 \\
<.1 \\
<.1\end{array}$ & $\begin{array}{r}<.1 \\
<.1 \\
.1 \pm \quad .1 \\
<.1\end{array}$ \\
\hline $\begin{array}{l}436-=-- \\
437-=- \\
440-\cdots- \\
467-\cdots- \\
474=---\end{array}$ & $\begin{array}{l}1 / 25-23 \mathrm{~L} 1 \\
1 / 26-1 \mathrm{~J} 1 \\
1 / 32-9 \mathrm{M} 1 \\
2 / 1 \mathrm{~W}-10 \mathrm{Cl} 1 \\
3 / 28-28 \mathrm{M} 2\end{array}$ & $\begin{array}{l}6-16-58 \\
6-17-58 \\
6-18-58 \\
4-21-58 \\
6-16-58\end{array}$ & $\begin{array}{c}<13 \\
15 \\
32 \\
<8 \\
6.2\end{array}$ & $\begin{array}{l}<.1 \\
<.1 \\
<.1 \\
<.1 \\
<.1\end{array}$ & $\begin{array}{r}.1 \\
2.0 \pm 0.1 \\
.1 \pm 0.2 \\
.4 \pm .1 \\
.1\end{array}$ \\
\hline \multicolumn{6}{|c|}{ IDAHO } \\
\hline $518----$ & $39 \mathrm{~N} / 5 \mathrm{~W}-8 \mathrm{ab} 2$ & $9-29-55$ & $<10$ & 0.6 & $<0.1$ \\
\hline
\end{tabular}

TABLE 3.-Radioactivity and radioactive-chemical analyses of ground water in the basalt of the Columbia River Group, Washington, Oregon, and Idaho 

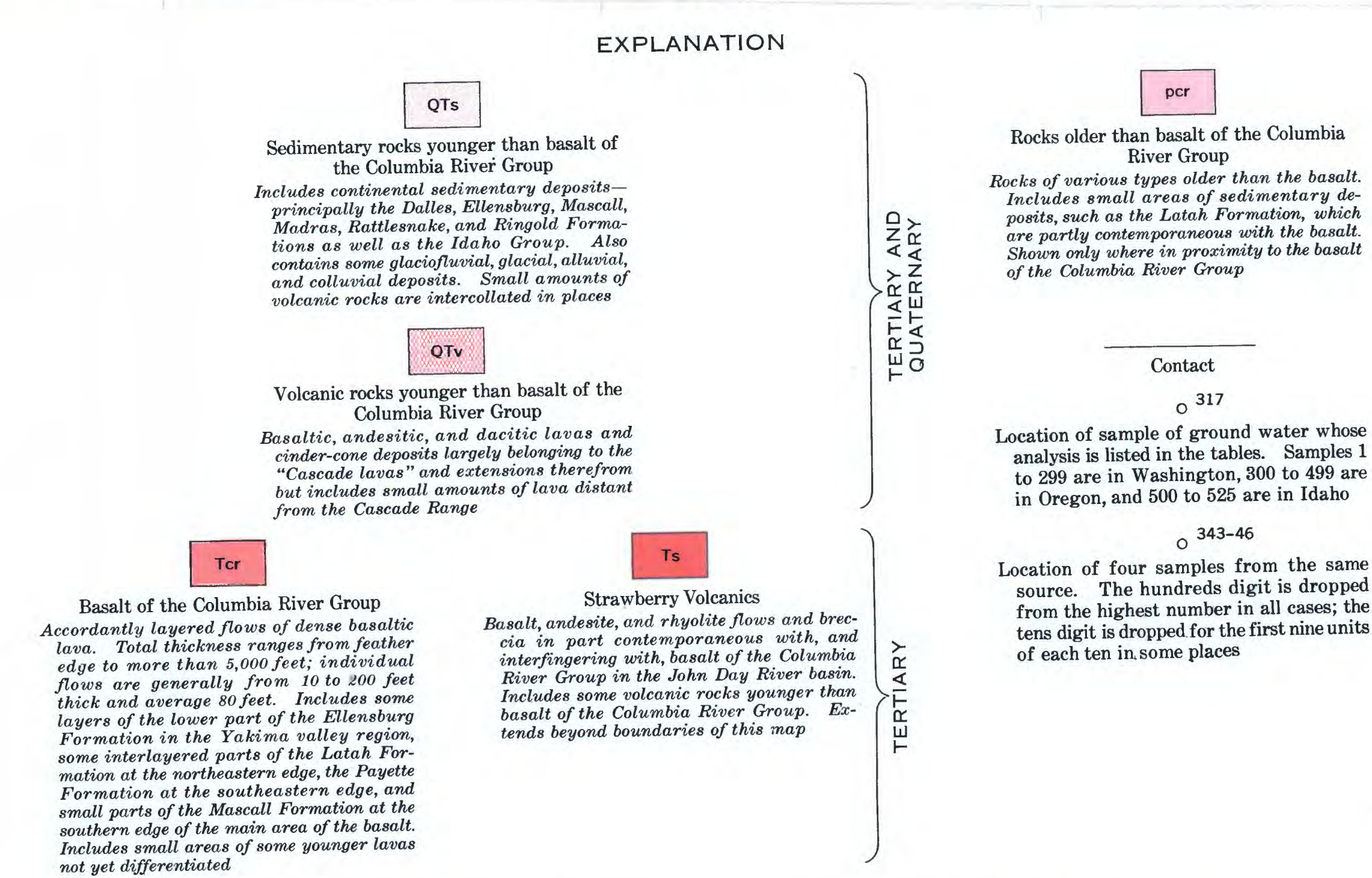

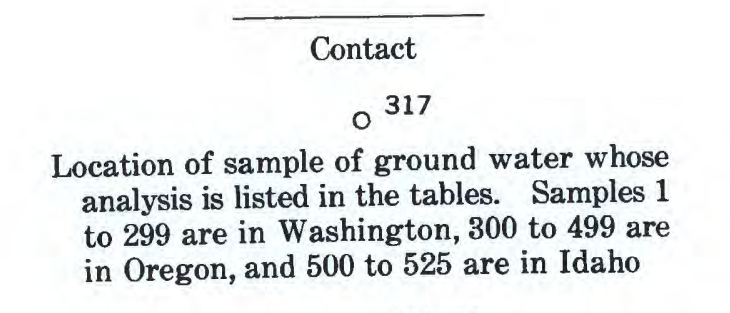

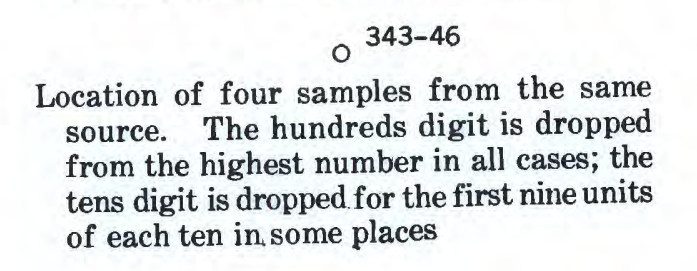

incudes small areas of some younger lat
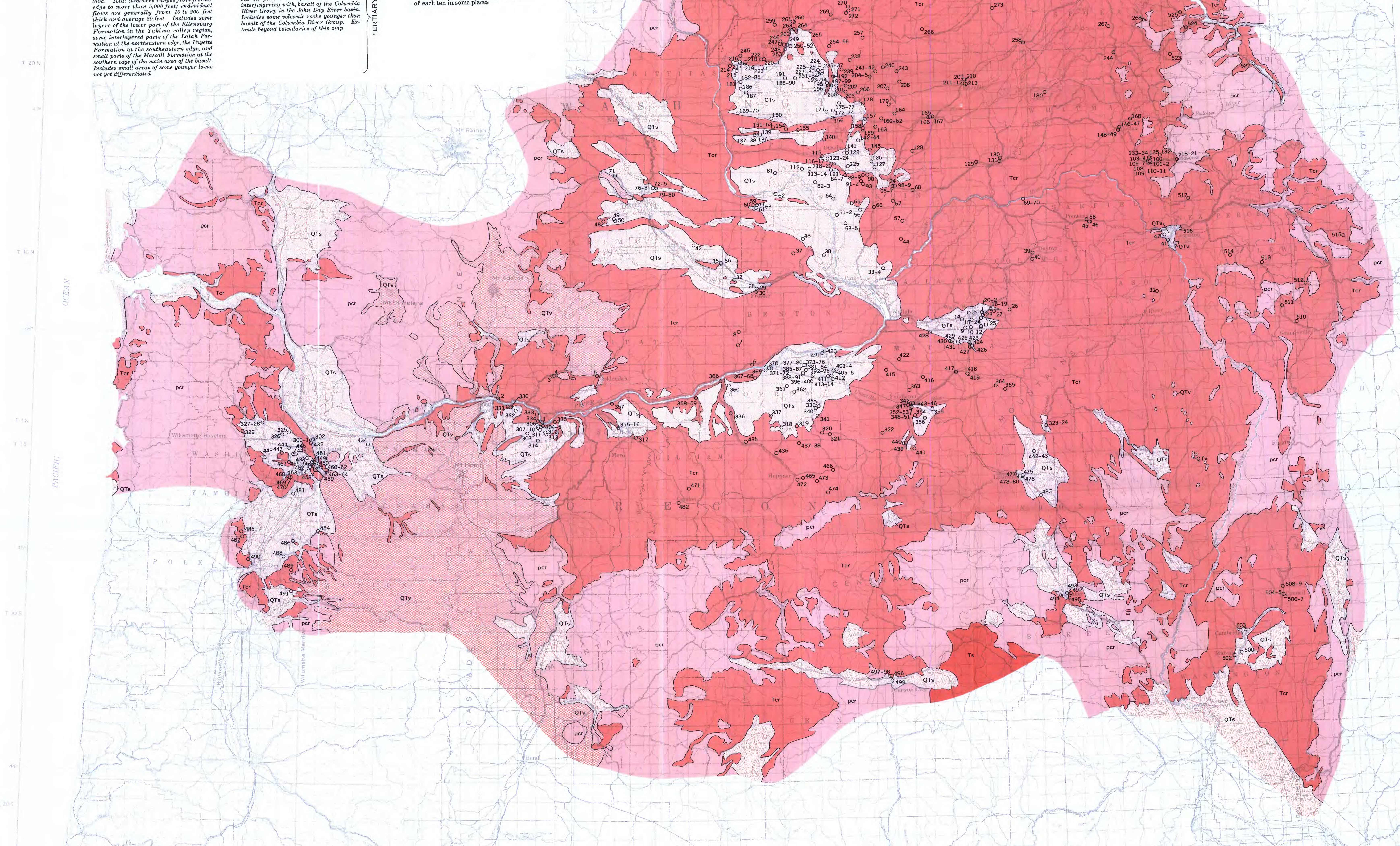

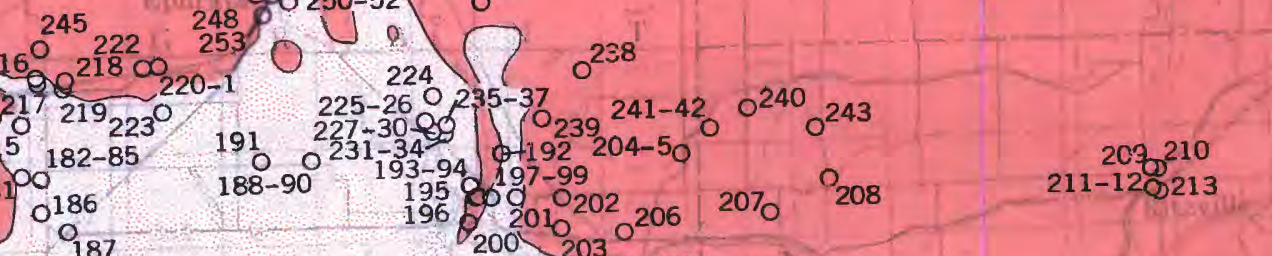

